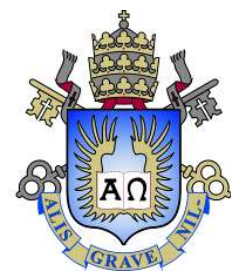

Luiz Felipe Waitz

\title{
Um estudo sobre a educação neoliberal na Igreja Universal do Reino de Deus
}

Dissertação de Mestrado

Dissertação apresentada ao Programa de Pós-graduação em Direito como requisito parcial para obtenção do grau de Mestre em Direito.

Orientador: Prof ${ }^{\circ}$. Adriano Pilatti 


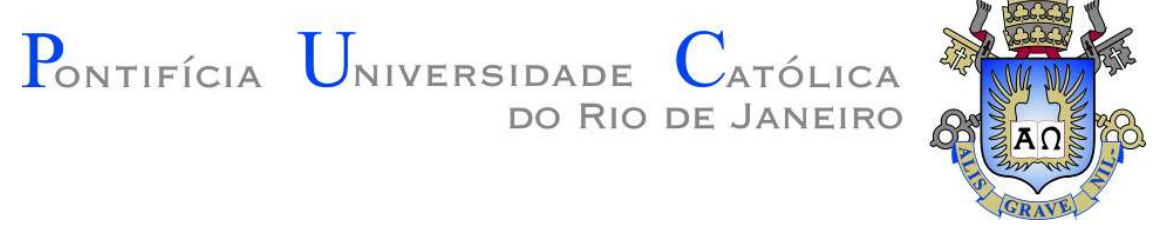

Luiz Felipe Waitz

\title{
Um estudo sobre a educação neoliberal na Igreja Universal do Reino de Deus
}

\begin{abstract}
Dissertação apresentada como requisito parcial para obtenção do grau de Mestre pelo Programa de Pósgraduação em Direito do Departamento de Direito da PUCRio. Aprovada pela Comissão Examinadora abaixo assinada.
\end{abstract}

Prof. Adriano Pilatti

Orientador

Departamento de Direito - PUC-Rio

Prof. Francisco de Guimaraens

Departamento de Direito - PUC-Rio

Prof. Ronaldo Rômulo Machado de Almeida

UNICAMP

Rio de Janeiro, 12 de abril de 2019. 
Todos os direitos reservados. É proibida a reprodução total ou parcial do trabalho sem autorização da universidade, da autora e dos orientadores.

\section{Luiz Felipe Waitz}

Graduou-se em Direito na Pontifícia Universidade Católica do Rio de Janeiro (PUC-Rio) em 2016. É Advogado. Desenvolve atividades de pesquisa no campo do Direito e na Política e tem como principais áreas de interesse: movimentos neopentecostais e neoliberalismo.

Ficha Catalográfica

Waitz, Luiz Felipe

Um estudo sobrea educação neoliberal na Igreja Universal do Reino de Deus / Luiz Felipe Waitz; Orientador: Adriano Pilatti - Rio de Janeiro: PUC, Departamento de Direito, 2019.

$149 f ; 30 \mathrm{~cm}$

Dissertação (mestrado) Pontifícia Universidade Católica do Rio de Janeiro, Departamento de Direito.

Inclui referências bibliográficas.

1. Direito - teses. 2. Igreja Universal do Reino de Deus. 3. Neopentecostalismo. 4. Discurso neoliberal. I. Pilatti, Adriano. II. Pontifícia Universidade Católica do Rio de Janeiro. Departamento de Direito. III. Título. 


\section{Dedicatória, ou uma história inédita sobre este trabalho}

Ao terminar a minha monografia (lá se vão quase três anos), decidi dedicála ao projeto de uma sociedade mais justa. Era minha primeira aventura acadêmica e, naquele momento, eu buscava lançar as sementes de um projeto maior que me levasse ao mestrado, ao doutorado e, quiçá, à desejada docência.

Com este trabalho, colho, com muita alegria, os primeiros frutos dessas sementes. Era necessário, todavia, que o ideal de justiça, ou de pelo menos uma alternativa humana e democrática ao que está aí, fosse lembrado também. Este trabalho foi escrito em dias de luta, dias de glória, conforme a canção; a ideia por trás da obra ficou cozinhando por meses na minha cabeça até que eu pusesse a primeira palavra no papel. Foi escrito em pouco tempo, portanto, ao longo do ano de 2018. O tempo para o escritor de um trabalho acadêmico é sempre breve, e 2018 foi mais breve ainda: começou em 14 de março, com o assassinato bárbaro de uma vereadora negra, favelada, lgbt e socialista, e do motorista que dirigia na ocasião. Terminou em 28 de outubro, com a eleição de algo cujas posturas de louvor a toda espécie de execrável vai contra qualquer coisa que atende pelo nome de decência. Assim, 2018 foi o palco da ópera dos horrores ensaiados nos picadeiros de anos precedentes.

No ano anterior, acompanhei silenciosamente o sofrimento gritante de toda a comunidade da UERJ, vítima dos descasos de um Estado que nasceu em 1500 predando gente. $\mathrm{O}$ trato desumano aos professores, funcionários e alunos se materializou para mim nas minhas figuras amigas que tinham na UERJ a sua casa, que alguns queriam transformar em estacionamento. Mas nem tudo é espinho no roseiral. Em 09 de setembro de 2017, na querida Livraria Leonardo da Vinci, esbarrei com dois franceses que ficaram conversando comigo algumas horas sobre Qu'est ce que le néoliberalisme? Na ocasião, comprei dois livros deles: A nova razão do Mundo e Comum. Fascinado pela análise de um campo de pesquisa novo para mim, ao mesmo tempo sofrendo junto aos meus pela UERJ, liguei os pontos: O que a situação da UERJ tem a dizer sobre o neoliberalismo? 
Com o tempo mudei o tema, para muito, para pouco, mas a ideia teve origem aí. Por isso, quero dedicar meu trabalho àquilo que, conforme Dardot escreveu no meu exemplar, seja o droit du commun. É dedicado à esperança de um futuro potente e espinosanamente democrático que seja a negação de 2018

Por isso, dedico esse trabalho, com muito carinho:

Ao meu tio, Luís Fernando Dorvillé, em quem homenageio todos os professores e funcionários da UERJ.

Aos meus amigos, Daniel Medeiros e Rafael Augusto, em quem homenageio todo o bravio alunato daquela universidade.

No momento em que algo de podre no reino dos bruzundangas ameaça aquilo que trago gravado no espírito como senso grave da ordem, espero que esse trabalho, escrito em um passado de tempos de angústia, seja lido em um futuro de tempos venturosos.

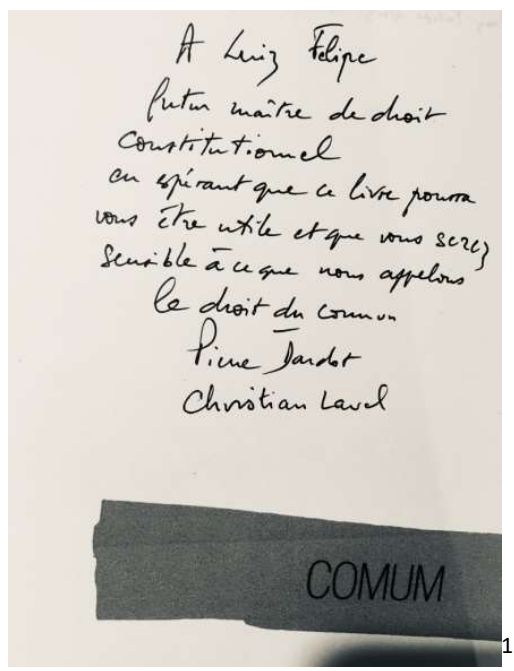

\footnotetext{
1 "Ao Luiz Felipe, futuro mestre em direito constitucional, esperamos que este livro te possa ser útil e que você seja sensível àquilo que chamamos de 'o direito do comum' " - Pierre Dardot \& Christian Laval
} 


\section{Agradecimentos}

Para que esse trabalho ficasse pronto, foi-me indispensável a ajuda, apoio e compreensão de várias pessoas, a quem devo lembrar e agradecer.

Primeiramente, aos meus pais, Luiz Eduardo e Marilisi, por serem as pessoas que são e por terem permitido os voos do filho que o levaram ao mestrado. Por terem sempre me incutido o amor à leitura, ao aprendizado e ao conhecimento e, principalmente por se orgulharem do menino que hoje deseja ser professor.

Em segundo lugar, aos meus "pais acadêmicos", os membros da minha banca, em especial ao professor Adriano Pilatti, único ponta-grossense torcedor do Botafogo que eu conheço, orientador na dissertação e na vida, mestre e amigo nas boas e más horas, e exemplo sempre marcante de erudição e persistência na luta contra os barbarismos. Aos demais membros; os professores Francisco de Guimaraens, pelos ensinamentos e pelos livros que me emprestou para este trabalho, cuja guarda e leitura me foram muito proveitosas; ao professor Ronaldo de Almeida, que teve a disposição de ler a minha dissertação e se deslocar até o Rio de Janeiro para participar da minha banca, e que para além do prazer da boa vontade e dos elogios ao trabalho, fez observações de grande relevância para o aprimoramento dele. Também ao Professor José Maria Gómez, que em razão das circunstâncias não pôde estar presente na banca, mas que, para além de ter expresso atenção ao trabalho, fez minhas primeiras indicações de leitura sobre o neoliberalismo, quando a minha pesquisa ainda era embrionária.

Agradecimentos também a todos os meus outros professores, mestres e amigos, que nesses dois anos de mestrado me ensinaram mais do que o tempo de uma vida permitiria: Adrian Sgarbi, Adriana Vidal, Antonio Pele, Bethania Assy, Carlos Plastino, Fabio Leite, Florian Hoffmann, Gisele Cittadino, Luiz Eduardo Melin, Marcia Nina Bernardes Noel Struchiner, Renato Lessa. Agradeço também a todos os funcionários da PUC-Rio que me ajudaram até mesmo nos momentos em que eu nem sabia que precisava de ajuda, em especial os queridos Anderson e Carmen, e também à Dona Marlene, a quem eu lego o "jardim" que plantei nos vasinhos do oitavo andar, e que ela sempre admirou. 
Agradeço a todos os meus amigos, começando pelos meus colegas de turma do "mestrado do centenário" (2017-2019), pelas experiências, amizades e aprendizado que me proporcionaram, em especial o meu caro Igor Bernardo, companheiro desde a graduação. Relembro as amizades e aprendizados colecionados durante a minha passagem pelo grupo "Terras e Lutas", e pelo "Grupo do Melin". Agradeço aos meus colegas de trabalho do PPMKF Advogados pela paciência e compreensão com o mestrando e seu tempo, e aos meus colegas e alunos do pré-vestibular São Francisco de Paula, onde descobri o amor ao ensino.

Por fim, um agradecimento especial vai à minha colega pisana Maria Francisca, que foi a primeira a ouvir a ideia que deu origem a este trabalho. Foi também a primeira a achar que eu não estava louco por escrever sobre isso.

Se os defeitos deste trabalho são meus, a alegria e os eventuais méritos dele devem ser compartilhados com vocês. Muito obrigado. 


\section{Resumo}

Waitz, Luiz Felipe; Pilatti, Adriano. Um estudo sobrea educação neoliberal na Igreja Universal do Reino de Deus. Rio de Janeiro, 2019, 149p. Dissertação de Mestrado - Departamento de Direito, Pontifícia Universidade Católica do Rio de Janeiro.

Este trabalho tem por objetivo promover o estudo do neoliberalismo enquanto nova razão do mundo, conforme estudado por Pierre Dardot e Christian Laval, e do neopentecostalismo, utilizando a Igreja Universal do Reino de Deus como paradigma, para investigar a hipótese de um processo de educação neoliberal por meio da prática religiosa neopentecostal. Nesse cenário, pretende-se analisar o neopentecostalismo e o neoliberalismo como estruturas e práticas que são produtos de experiências históricas que lhes determinaram a forma que têm hoje. Busca-se demonstrar que tanto o neoliberalismo quanto o neopentecostalismo são entidades normativas criadoras de subjetividades e de mundos, evitando algumas interpretações calcificadas de que o neoliberalismo é um mecanismo interno do capitalismo para aumentar ou preservar a sua existência enquanto o neopentecostalismo é uma forma de ideologia religiosa que se alimenta da ignorância de fiéis pauperizados. Neste trabalho, neoliberalismo e neopentecostalismo são abordados como experiência e estrutura, analisando ao mesmo tempo, como o universo simbólico de cada um deles emerge de uma estrutura (A Igreja de um lado, o Estado, o mercado de outro) para constituir o sujeito neopentecostal-neoliberal que também se orienta por uma estrutura: a empresarial-concorrencial. O trabalho explora como o catecismo da IURD incute uma ética empresarial nos seus fiéis e em que medida essa construção de sujeito guarda relação com o processo de educação do sujeito neoliberal preconizada por Ludwig von Mises e Friedrich Hayek.

\section{Palavras-chave}

Neoliberalismo; Igreja Universal; Neopentecostalismo; Teologia da Prosperidade; Evangelismo Brasileiro 


\section{Abstract}

Waitz, Luiz Felipe; Pilatti, Adriano (Advisor). A study on neoliberal education within the Universal Church of the Kingom of God Rio de Janeiro, 2019. 149p. Dissertação de Mestrado - Departamento de Direito, Pontifícia Universidade Católica do Rio de Janeiro.

This thesis aims to promote the study of neoliberalism as a new reason of the world as developed by Pierre Dardot and Christian Laval, and of neopentecostalism, using the Universal Church of the Kingdom of God (UCKG) as matrix, to investigate the hypothesis of a process of neoliberal education through neopentecostal religious practices. Within this frame, my intention is to analyze both neopentecostalism and neoliberalism as structures and practices that are results of historical experiences which shaped them as they present themselves today. I intent to demonstrate that both neoliberalism and neopentecostalism are normative entities bearing the capacity of producing subjects and worlds, avoid, therefore, to make use of some petrified interpretations concerning neoliberalism as an internal mechanism of capitalism to grow or preserve itself, and concerning neopentecostalism as a religious ideology which feeds itself from the ignorance of poor people. In this thesis, neoliberalism and neopentecostalism are undertaken as experience and structure, in which I seek to analyze how the symbolical universe of each of them emerges from a structure (on one side, the Church; on the other, the State and the Market), to constitute a neopentecostal-neoliberal subject, which also guides himself by another structure: that entrepreneurial-concurrencial. This thesis explores how the catechism of UCKG teaches an entrepreneurial ethics on its followers and in which point this construction of subjectivity is related to the process of education of the neoliberal man, preconized by Ludwig von Mises and Friedrich Hayek.

\section{Keywords}

Neoliberalism, Universal Church, Neopentecostalis, Theology of Prosperity, Brazilian Evangelism. 


\section{Sumário}

Introdução - Servos maus. Servos inúteis 12

Quadro Teórico-Metodológico 22

1 Os Camelos: Definindo Neopentecostalismo 29

1.1 Religião no século $X X$ e os limites de uma teoria da secularização 31

1.2 Do pentecostalismo ao neopentecostalismo: as ondas pentecostais. 40

1.3 O neopentecostalismo: surgimento da Igreja Universal. 48

1.4 O Credo Macedo-lurdiano. 52

1.5 Ser e não ser: o público da Universal. $\quad 61$

1.6 'Aedificabo ecclesiam meam': A Estrutura da Igreja Universal 64

$\begin{array}{ll}1.7 \text { Síntese conclusiva } & 70\end{array}$

2 O Buraco da Agulha: Definindo Neoliberalismo 72

2.1 O Colóquio Walter Lippmann e a Crise do Liberalismo Clássico 75

2.2 O ordoliberalismo, ou neoliberalismo "alemão" 80

2.3 Lippmann, Mises, Hayek 86

$\begin{array}{ll}2.4 \text { Síntese conclusiva } & 105\end{array}$

3 "Vinde a nós o Vosso reino": O governo do homem iurdiano. 106

3.1 Governamentalidade e Biopolítica. 106

3.2 As verdades e as normas. 114

3.3 As gaiolas simbólicas do homem iurdiano. 119

3.4 A construção do homem iurdiano. 133

$\begin{array}{ll}3.5 \text { Síntese conclusiva } & 138\end{array}$

4 Conclusão 140

5 Referências bibliográficas 146 
" Pequei, Senhor; mas não porque hei pecado,

Da vossa alta clemência me despido; Antes, quanto mais tenho delinquido, Vos tenho a perdoar mais empenhado.

Se basta a vos irar tanto pecado, A abrandar-vos sobeja um só gemido: Que a mesma culpa, que vos há ofendido, Vos tem para o perdão lisonjeado.

Se uma ovelha perdida já cobrada,

Glória tal e prazer tão repentino Vos deu, como afirmais na Sacra História:

Eu sou, Senhor, a ovelha desgarrada, Cobrai-a; e não queirais, Pastor Divino, Perder na vossa ovelha a vossa glória."

- Gregório de Matos, 'A Jesus Cristo, nosso Senhor' 


\section{Introdução - Servos maus. Servos inúteis}

$\mathrm{Na}$ véspera de natal de 2018, o site do Instituto Mises Brasil, think tank neoliberal brasileiro, publicou um texto chamado "A Parábola dos Talentos: A Bíblia, os empreendedores e a moralidade do lucro"2. Seu autor era o padre norteamericano Robert Sirico, fundador do Acton Institute, ligado à Direita Católica e membro da Sociedade de Mont-Pèlerin, e tinha por tema a parábola extraída do evangelho de Mateus (Mt. 25; 14-30) ${ }^{3}$. No texto, o autor tenta apresentar uma interpretação "empresarial" à passagem bíblica, pretendendo demonstrar que por trás da história, o Criador teria imbuído à criatura o espírito empreendedor e que, sendo este obra da Graça, não só seria errado não fazer seu uso como a ganância, até então pecado capital, subitamente mudava de lado e passava de falha a virtude. Assim, Deus se encoleriza com o servo mau e inútil, aquele que, ao invés de investir o talento que lhe cabia, o enterrou. Padre Sirico conclui: "A religião deve reconhecer o empreendedorismo pelo que ele é: uma vocação".

A interpretação pouco ortodoxa do Padre Sirico à parábola explicita o liame entre o processo de construção do sujeito neoliberal e uma subjetividade neopentecostal em perspectiva que procuro desenvolver nestas páginas. Este

\footnotetext{
${ }^{2}$ Disponível em https://mises.org.br/Article.aspx?id=2046

${ }^{3}$ Mt. 25; 14-30: "Pois é como um homem que, antes de viajar para fora, convocou seus servos e lhes confiou os seus bens. A um deu cinco talentos, a outro dois e a ainda outro um, a cada um segundo a sua capacidade, e viajou para fora. Aquele que recebeu cinco talentos foi imediatamente negociar com o dinheiro, e ganhou mais cinco. Do mesmo modo, aquele que recebeu dois ganhou mais dois. Mas o servo que recebeu apenas um foi embora, cavou um buraco no chão e escondeu o dinheiro do seu senhor. Depois de muito tempo o senhor daqueles servos voltou e ajustou contas com eles. Então o que havia recebido os cinco talentos se apresentou e trouxe outros cinco talentos, dizendo: ' $O$ senhor me confiou cinco talentos; veja, ganhei mais cinco talentos.' Seu senhor lhe disse: 'Muito bem, servo bom e fiel! Você foi fiel ao cuidar de poucas coisas. Vou encarregá-lo de muitas coisas. Participe da alegria do seu senhor.' A seguir, aquele que havia recebido dois talentos se apresentou e disse: 'O senhor me confiou dois talentos; veja, ganhei mais dois talentos.' Seu senhor lhe disse: 'Muito bem, servo bom e fiel! Você foi fiel ao cuidar de poucas coisas. Vou encarregá-lo de muitas coisas. Participe da alegria do seu senhor.' "Por fim, o servo que havia recebido um talento se apresentou e disse: 'Eu sabia que o senhor é um homem exigente, que colhe onde não semeou e ajunta onde não espalhou. Por isso fiquei com medo e fui esconder no chão o seu talento. Aqui está o que é seu.' Em resposta, seu senhor lhe disse: 'servo mau e inútil, quer dizer que você sabia que eu colho onde não semeei e ajunto onde não espalhei? Então, você devia ter entregado meu dinheiro aos banqueiros, e, na minha vinda, eu o teria recebido com juros. 'Portanto, tirem dele o talento e deem-no àquele que tem dez talentos. Pois a todo aquele que tem, mais será dado, e ele terá abundância. Mas daquele que não tem, até mesmo o que tem será tirado. E lancem o servo inútil na escuridão lá fora. Ali é que haverá o seu choro e o ranger dos seus dentes.' "
} 
trabalho tem por objetivo explorar as possibilidades de comparação dessas subjetividades: a subjetividade neopentecostal representada pelos fiéis da Igreja Universal do Reino de Deus (IURD) e a subjetividade neoliberal. Em apertadíssima síntese, cumpre observar que traços, entre elementos simbólicos e pragmáticos componentes da identidade que a IURD cria nos seus fiéis, se relacionam com o processo educacional neoliberal de Ludwig von Mises e Friedrich Hayek visando a construção de um sujeito regido pelo mercado como gramática da vida.

De modo mais minucioso, parto do pressuposto de que o neoliberalismo não é resultado de uma operação perfeitamente acabada desenvolvida no bojo do capitalismo; e nem é, por outro lado, fruto absolutamente contingente da História. Antes, é consequência de um projeto de alternativa ao liberalismo clássico, pensado pela primeira vez na década de 1930, mas que dependeu de outras experiências para assumir a forma que tem hoje. Estabelecidos esses pontos, pretendo demonstrar, no capítulo 1, que o neopentecostalismo também emergiu de uma sequência de experiências eclesiológicas produzidas num período de reformulação das simbologias religiosas clássicas, e que a teologia da prosperidade é uma das suas marcas constitutivas. Exploro então o modo como essa marca é interpretada dentro da Igreja Universal do Reino de Deus, junto a outras categorias, como "fé inteligente", para investigar seus usos na construção de uma educação empresarial nos fiéis daquela igreja. No capítulo 2, introduzo os dois principais projetos neoliberais - o chamado "alemão" e o "austroamericano" - focando neste último para discorrer sobre o que é a subjetividade empresarial, condição sem a qual uma governabilidade neoliberal não é possível e cuja construção é um processo de "educação para o mercado". O capítulo 3 é dedicado ao mecanismo normativo constitutivo das subjetividades estudadas, para estabelecer uma comparação entre a "subjetividade iurdiana" que explorei no capítulo 1 com o sujeito neoliberal, empresário de si mesmo, investigado no capítulo 2 , mostrando como é possível que o universo simbólico da IURD se combina com o neoliberalismo enquanto governabilidade biopolítica da sociedade.

Iniciei invocando o texto de um padre católico, mas que guarda relação com o objetivo deste trabalho porque proporciona justamente o encontro entre os universos do neoliberal e do religioso como experiências que se cruzam e subscrevem o primeiro ponto que guia meu trabalho: tratar o neoliberalismo e o 
neopentecostalismo como resultados contingentes de uma série de experiências históricas que se desenvolveram ao longo do século XX. Destaco os vocábulos resultado e experiência, para contraditar a interpretação de que o neoliberalismo foi um objetivo, pré-determinado pelo Capital e imposto de maneira quase conspiratória ao mundo da vida. Ao mesmo tempo, e também em função de experiências, o universo simbólico do religioso transforma seu próprio sentido, permitindo que o que era pecado de repente vire virtude. Por esse motivo, o resultado dessa pesquisa não será denunciar tal ou qual situação, mas partindo da experiência neoliberal e da experiência neopentecostal, verificar que encontros são possíveis de serem extraídos desses dois fenômenos, e que possam explicar a interpretação do empreendedorismo como vocação, encontrado nas palavras do Padre Sirico.

Por isso, o trabalho começa com um panorama sobre o cenário religioso atual e as mudanças que as últimas transformações do capitalismo projetaram nesse horizonte. Em outras palavras, buscarei situar o nascimento do neopentecostalismo numa conjuntura que procura explicar o seu surgimento a partir de experiências que, em certa medida, também foram apreendidas no desenvolvimento do neoliberalismo ao longo do século passado, para entender por exemplo por que, de repente, o empreendedorismo passou a ser uma vocação religiosa, e melhor situar a frase do Padre Sirico como produto de um contexto específico.

Conforme se tentará demonstrar no curso do texto, o pentecostalismo e o neopentecostalismo, fenômenos relativamente recentes na história do cristianismo, se inscrevem como grupos muito particulares dentro da vasta gama de manifestações religiosas cristãs, sendo necessário explorá-los de maneira estrutural e buscar suas origens para estabelecer a diferença entre eles. Nesse trabalho considerei o neopentecostalismo um produto histórico do pentecostalismo. Não é, contudo, um produto histórico imediato e, apesar do nome, existem mais diferenças do que semelhanças entre os dois. Dentro do próprio neopentecostalismo, houve a necessidade de se escolher uma igreja para tratar como marco teórico, e para tanto, tomei a Igreja Universal. Tratar de mais de uma igreja faria o trabalho muito extenso ou substancialmente raso. Também foram feitas delimitações teóricas para o estudo do neoliberalismo. Todas essas delimitações estão explicadas na exposição do quadro teórico-metodológico, mais adiante no texto. 
Os motivos que me fizeram investigar esse tema foram muitos, e cumpre enumerá-los. Para além do interesse que nutro pelo religioso desde bem novo, o tema envolve dois temas recentes e importantes. De um lado, há a explosão do neopentecostalismo brasileiro, numa carreira meteórica encabeçada pela IURD, seguida pelas igrejas que se separaram dela. Esse crescimento não foi medido apenas em número de fiéis e templos, mas também em número de denominações, de crescimento de mercado endógeno (livrarias, gravadoras, marcas de roupa, itens pessoais. Tudo voltado para um mercado evangélico). Também ficou marcante a maior presença dos evangélicos neopentecostais no cenário brasileiro, ocupando uma porcentagem expressiva da população religiosa ${ }^{4}$. Acompanhando essa expansão no número de fiéis, veio a expansão nos meios de comunicação, na presença no cenário social e político brasileiro. Foi com base nessa expansão, que já era chamativa na virada da década de 80 para a de 90 , que um grupo de intelectuais brasileiros - entre teólogos e sociólogos da religião - começaram uma série de estudos sobre o fenômeno neopentecostal. Essa empreitada deu frutos, e gerou novos trabalhos nos anos subsequentes. Com o crescimento cada vez mais expressivo dos neopentecostais e com o avanço desses para a política com o projeto de poder da IURD para o Brasil, que com a eleição de Marcelo Crivella para Prefeitura do Rio de Janeiro em 2016 e o endosso à campanha vitoriosa de Jair Bolsonaro em 2018, mostrou sua força, a atenção ao neopentecostalismo brasileiro deve ser atual ${ }^{5}$.

De outro lado há a escalada do neoliberalismo, que vem se impondo desde o final da década de 1980, para além de somente uma reorganização econômica, como alternativa ao modelo de Estado de bem estar social, ou como uma corrente de pensamento econômico que se opõe ao keynesianismo. O neoliberalismo,

\footnotetext{
${ }^{4}$ Segundo o censo religioso do IBGE de 2010, os católicos, que tradicionalmente dominam o cenário religioso brasileiro, somavam 123.280 .172 indivíduos (Cerca de $65 \%$ da população, conforme o censo). A IURD ficava com 1.873.243 fiéis (apesar da igreja afirmar ter mais de 8 milhões de fiéis só no Brasil), e no campo evangélico, ficava atrás de denominações pentecostais como a Assembleia de Deus (com 12.314.410 fiéis) e a Congregação Cristã no Brasil - CCB (2.289.634 seguidores). Apesar de não figurar como a maior denominação evangélica em número de fiéis, foi a igreja que apresentou a maior taxa de crescimento no campo e que apresenta o maior número de templos (7.157, segundo a Igreja). A maior taxa de crescimento de templos, todavia, foi da Igreja Mundial do Poder de Deus - IMPD.

${ }^{5}$ Ainda sobre o censo de 2010, o declínio católico e a ascensão evangélica, remeto ao artigo de Ricardo Mariano "Mudanças no campo religioso brasileiro no censo 2010", disponível em https://seer.ufrgs.br/debatesdoner/article/view/43696/27488
} 
conforme tratado aqui, é uma nova razão de mundo e nesse sentido tomo por base a minuciosa análise feita por Pierre Dardot e Christian Laval. Tratar o fenômeno neoliberal dessa forma é uma maneira de se encarar a realidade e o sentido das coisas e de estabelecer uma nova forma de governabilidade dos corpos, do tempo, da vida. Debates sobre seus pilares econômicos e suas consequências políticas não são suficientes para explicar o fenômeno de uma maneira expressiva pois deixam de alguns elementos essenciais à sua anatomia. É mister lançar olhares sobre o neoliberalismo enquanto produtor de novas subjetividades e controlador dessas subjetividades produzidas. Essa nova subjetividade atende por vários nomes: homo agens, homem-empreendedor, indivíduo-empresa, empresário de si mesmo ou talvez a mais contraditória e poeticamente perversa de todas: capital humano. Assim, o trabalho não está construído sob definições "clássicas" do neoliberalismo tais como "diminuição do Estado" ou como numa abordagem de "ideologia de classe".

Da mesma maneira, o neopentecostalismo e a eventual relação que guarda com o neoliberalismo foi estudado de maneira diferenciada do que se costuma considerar. Para este trabalho, pentecostalismo e neopentecostalismo são veículos extremamente capazes de produção de novas subjetividades e potencialização dos sujeitos.

O tratamento costumeiro dado aos pentecostais e neopentecostais é resumido na expressão "religião de pobre". Esse foi, por exemplo, o tratamento dado por Jessé Souza no capítulo 10 de "A Ralé Brasileira" (em coautoria com Edson Rocha e Roberto Torres), segundo o qual a igreja neopentecostal ocupa o locus da espiritualidade da ralé que, como é desprovida de futuro, se rende às "práticas parasitárias" dos "pastores trambiqueiros" na esperança de suprir seu vazio existencial miserável. Essa interpretação descarta, todavia, logo de início um detalhe crucial da ética neopentecostal, qual seja o seu potencial disciplinador, sua capacidade de criação de sentido de vida, de ética profissional, de conduta moral e de superação de si próprio. O pentecostalismo e o neopentecostalismo não podem ser considerados portanto como "parasitários de vida". Antes são fatores constitutivos da vida do crente. O fator pentecostal é potencializador do sujeito. Esse é um ponto que parte da crítica não enxerga, mas que será crucial para este trabalho, conforme o capítulo 3 . Se a crítica normalmente se atenta à prática do 
dízimo e aos abusos por parte dos líderes religiosos (quando não encapsulam os pentecostais na taxa de "seita") fracassam ao esquecer os vários projetos sociais mantidos por várias dessas igrejas: são programas de recuperação de dependentes químicos, reestruturação familiar, passando por cursos de alfabetização para adultos, pré-vestibulares comunitários e aulas de ofícios que transformam o sujeito que estava na sarjeta no binário "fiel-cidadão", agora alfabetizado, empregado, casado, limpo dos vícios e que almeja ter seu próprio negócio. Em algumas igrejas pentecostais mais tradicionais, a guisa de exemplo, a formação humanística se completa com a educação musical, que marca a notável liturgia evangélica de denominações como a CCB. A ralé ficou para trás ${ }^{6}$.

Outro tratamento deficiente se deu no âmbito do debate acadêmico, no qual o neopentecostalismo demorou muito tempo para ser estudado como um fenômeno expressivo, marcante e dotado de uma produtividade de valores e subjetividades próprias, ficando submetido à pecha de "mercados de fé", "agências de assistência espiritual" ou como uma corrupção do pentecostalismo. As três expressões são equivocadas. O porquê será explicado ao longo do texto, mas à guisa de introito, importa observar que as igrejas neopentecostais são instituições hierarquizadas, disciplinadoras, com uma capacidade de adaptação quase plástica à constituição social e psíquica dos seus fiéis. Estão longe de ser, portanto, coisas pequenas, ou institucionalmente precárias. O tamanho da Igreja Universal, da Igreja Internacional da Graça de Deus e da Igreja Mundial do Poder de Deus - cismáticas da IURD atestam seu poder. Além disso, seu tamanho se faz presente por todo o Brasil, e não está mais limitada às periferias e áreas socialmente marginalizadas. A IURD em particular possui templos em bairros de luxo das capitais brasileiras ${ }^{7}$. Também a sua marca teológica está bem definida: o neopentecostalismo promoveu uma total revalorização da simbologia cristã, instituindo uma nova gramática na qual "Deus",

\footnotetext{
${ }^{6} \mathrm{O}$ antropólogo brasileiro Juliano Spyer realizou um trabalho de campo em uma comunidade marginal de Salvador entre abril de 2013 e agosto de 2014, no qual analisou, entre outras coisas, o papel que a igreja evangélica local desempenhava no espaço social da comunidade. A igreja, num certo sentido, provia à comunidade aquilo que o Estado negligenciava, de alfabetização pela leitura bíblica a custódia de crianças, como se fosse uma creche. Seu trabalho rendeu o livro "Social Media in emergent Brazil", que pode ser consultado na íntegra pelo endereço eletrônico http://discovery.ucl.ac.uk/10025054/1/Social-Media-in-Emergent-Brazil.pdf

${ }^{7}$ Conforme matéria do jornal Folha de São Paulo de 09/07/2017 "Igreja Universal estreia no metro quadrado mais caro do país", sobre a abertura de um templo da IURD no bairro carioca do Leblon. Confira-se: https://www1.folha.uol.com.br/poder/2017/07/1899616-igreja-estreia-no-metroquadrado-mais-caro-do-pais.shtml
} 
"diabo", "salvação" e os próprios papéis do homem e da fé são ressignificados e se destacam do protestantismo histórico e do próprio pentecostalismo clássico.

Toda essa vasta gama de signos produzidos e re-produzidos, alinhada à capacidade incontestável de diálogo das igrejas neopentecostais com o average brazilian, e o seu aparato disciplinar constituem a fábrica de produção da identidade neopentecostal. Um fiel da IURD, por exemplo, que foi "salvo" das "obras do diabo" - que podem ser o álcool, o fumo, as drogas, o jogo ou a luxúria - e passa a ser crente é atravessado pelo torvelino simbólico da igreja, que o imbui de um novo caráter, um processo disciplinar notável que comporta da higiene pessoal à ética empreendedora. Ele se autoimpõe uma nova forma de vida, com novas perspectivas de sucesso e fracasso na vida financeira, amorosa, social e familiar. Com o passar do tempo, o próprio indivíduo se torna veículo de expressão de sua subjetividade, seja no corpo, seja no comportamento, de modo a se identificar e se expressar como "crente".

Naturalmente a palavra "crente" não quer dizer muito além de "evangélico", de modo que um crente da IURD (neopentecostal) é completamente diferente de um crente da Assembleia de Deus (pentecostal), por exemplo. Mas isso já permite verificar a produção de identidades distintas, com processos de potencialização diversos. Tal potencialização, seja pentecostal ou neopentecostal, vai de encontro à perspectiva da expansão do neopentecostalismo entre a "ralé" enquanto "classe esvaziada de potência", e do próprio neopentecostalismo como instrumento de um espírito do capitalismo na modernidade periférica. Se a definição que Souza dá de ralé é a de um segmento social desprovido de perspectivas de futuro ("para quem o futuro é um eterno presente"), isso está em total desacordo com o espírito do neopentecostalismo, que tem o futuro como alvo imediato. $\mathrm{O}$ neopentecostalismo potencializa, conforme mencionado parágrafos acima.

Nesse veio, talvez sejam adequadas também algumas palavras sobre o que esse trabalho não é.

Em primeiro lugar, esse trabalho não tem um marco teórico weberiano. Qualquer um que queira ler essas páginas buscando uma releitura de Weber, da sua Sociologia das Religiões ou uma eventual ética neopentecostal e o espírito do neoliberalismo ficará decepcionado. O escopo de Weber não é o mesmo do que 
quero investigar aqui, primeiro porque aquele autor nunca conheceu o pentecostalismo (e tampouco o neopentecostalismo). Sua preocupação era a ética protestante calvinista, que em nada conversa com a ética da IURD ou de qualquer outra igreja neopentecostal. Seu objeto de investigação era o processo de racionalização do mundo, num momento em que o encantamento católico medieval, em virtude da reforma e de outros fatores, deixa de ser o promotor de sentido da vida e cessa como meio de discurso de unidade social. Esses papéis foram substituídos pela riqueza, produzida através do trabalho coletivo, no surgimento do capitalismo moderno. Não há nenhuma relação nem entre a ética protestante weberiana e a subjetividade neopentecostal (individualista por natureza), e nem entre o capitalismo primordial descrito por Weber e o neoliberalismo enquanto nova razão de mundo tratado por Dardot e Laval.

Este trabalho também não pretende, naturalmente, esgotar o assunto sobre os possíveis cotejos entre a identidade neopentecostal e o espírito neoliberal. De 2013 para 2018, identifiquei alguns poucos trabalhos acadêmicos que foram desenvolvidos nesse tema, nas diversas áreas do conhecimento, de modo que a temática neopentecostalismo-neoliberalismo é recente e tímida ainda. Há muito ainda para ser explorado, ventilado, debatido e estudado nessa área, e o recorte que realizo neste trabalho é muito selecionado: trato de apenas uma igreja, sigo um marco teórico para definição do que é neopentecostalismo, o que é neoliberalismo e justifico, na metodologia, o porquê de ter escolhido esses, e não outros. Um pesquisador ou pesquisadora que queira desenvolver um trabalho semelhante, mas usando um marco teórico diferente poderá, eventualmente, chegar a conclusões distintas, e ainda assim suscetíveis de acolhimento acadêmico.

Também devo asseverar que não posso, de forma alguma, esgotar um tema sobre o qual minha amplitude de conhecimento não é específica da área. Sou bacharel em Direito, e este trabalho foi realizado como dissertação de mestrado em Teoria do Estado e Direito Constitucional. O escopo que procuro seguir aqui é a formação de subjetividades e identidades, bem como o estudo do neoliberalismo como forma de governabilidade. Não sou teólogo e nem sociólogo da religião, apesar de muitas vezes, durante a pesquisa, ter travado contato com literatura teológica ou sociológica quando tratei do neopentecostalismo, ou filosófica, quando do neoliberalismo. Sobre essas áreas do conhecimento das quais posso conhecer 
algo por pesquisas próprias, mas não possuo a graduação acadêmica específica, eu reconheço que procurei construir meu argumento sobre as obras de acadêmicos de fora do Direito, procurando moldá-los ao meu trabalho mas sem jamais subverter, alterar ou modificar seus trabalhos.

Assevero também que, como essa dissertação tem uma temática religiosa, e uma particularmente delicada, este trabalho não tem finalidade de emitir qualquer juízo de valor - positivo ou negativo - sobre a Igreja Universal do Reino de Deus, sua liturgia, seus fiéis, sua crença ou qualquer outra denominação mencionada no trabalho. Sempre procurei tratar da IURD como ela é, como ela é tratada nos trabalhos acadêmicos descompromissados e, sempre que possível, procurei as análises que a própria Igreja faz sobre si mesma e seus adversários - seja por meio do seu site oficial (www.universal.org) ou por outros meios de comunicação, como pregações ou o jornal "Folha Universal", que li com frequência. Durante as pesquisas aprendi muito sobre a Igreja Universal e sua história polêmica, dizendose com frequência perseguida por seus adversários (e algumas vezes realmente sendo). Aprendi, nesse sentido, a olhar a Igreja com os olhos de um pesquisador, somente, afastando as paixões e os rumores, para me concentrar apenas no meu trabalho. Não procurei determinar nada como previamente estabelecido e evitar estereótipos e canais de discurso que eu sabia serem comprometidos com o louvor ou reprovação à IURD e à sua obra. Declaro também que não tenho religião alguma e que, para mim, a Igreja Universal é uma denominação cristã como qualquer outra. Assim a tratei neste trabalho. O resto é querela teológica.

Por fim, na escrita desse trabalho, travei um contato inédito com as liturgias pentecostal e neopentecostal. Conversei sem compromisso com alguns membros de algumas igrejas e aprendi muito sobre como se veem, como veem as outras igrejas e como exercem sua fé. Não podia deixar de registrar meu encanto com os hinários pentecostais, principalmente o da Congregação Cristã, cujas melodias e letras, apesar da simplicidade tão inerente àquela igreja, traduziam sentimentos verdadeiramente belos de uma fé bastante sincera e de uma esperança de potencialização. Em particular o hino 260 do hinário da CCB, para além da melodia suave, parece voltar ao sentido original da parábola dos talentos, e dar uma resposta um pouco mais humilde e adequada aos ditames do Padre Sirico: 
"Sou servo inútil, servo imperfeito

Vivo ansioso para ser aceito

Podes limpar-me, justificar-me

Se Tu o quiseres nada impedirá"

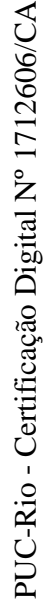




\section{Quadro Teórico-Metodológico}

A pesquisa realizada é, na sua maior parte, teórica. Envolveu uma carga considerável de leitura para delimitar melhor os dois polos entre os quais o trabalho se lastreia.

No tocante ao neopentecostalismo, obedeci à leitura de textos clássicos sobre a construção do novo movimento evangélico brasileiro, que começa com a publicação do livro do sociólogo da religião e pastor anglicano David Martin (Tongues of Fire: The Explosion of Pentecostalism in Latin America). A obra é um marco, e tem seu valor respeitado quando o assunto envolve pentecostalismo no Brasil. No entanto, é um livro antigo, lançado em 1990, e que preferenciou uma abordagem ampla e superficial do que uma mais delimitada e aprofundada. Foi, nesse sentido, um abre-alas para assentar as primeiras pedras do caminho que iria percorrer.

Trilhada essa primeira etapa, outra literatura foi utilizada para trazer um aspecto mais atual ao neopentecostalismo, e também com um recorte voltado para o Brasil. Nesse sentido, as leituras envolveram preliminarmente o artigo " $A$ vontade do Saber: Terminologias e classificações sobre o protestantismo brasileiro", de Emerson Giumbelli, que traçou um quadro geral do desenvolvimento dos estudos sobre o pentecostalismo e o neopentecostalismo no Brasil, casando o trabalho de teólogos com o de sociólogos da religião.

O cenário desdobrado por Giumbelli mostrou uma linha de pensamento muito interessante sobre o neopentecostalismo, que não chega a ser propriamente uma "escola" ou uma "tradição" de estudos sobre o fenômeno, mas que, indubitavelmente, indicava que havia um diálogo entre os pesquisadores. Foi assim que tomei contato com as obras de Mendonça, Brandão, Bittencourt, Hortal e Freston, culminando na de Mariano. Todos esses trabalhos, realizados entre o início dos anos 80 e o final dos anos 90, podem parecer antigos, mas demonstram uma maior dedicação ao tema neopentecostal pelos pesquisadores, durante um marco temporal que coincidiu com o período de maior crescimento da Igreja Universal do Reino de Deus no Brasil e sua expansão pelo mundo. 
Dessas obras, optei por tomar como marco teórico uma abordagem do neopentecostalismo como expressão religiosa desenvolvida a partir do pentecostalismo, mas diferente e separado dele em razão da ressignificação que promove do simbólico e das práticas pentecostais. Para a elaboração de tal construção teórica, fiz bastante uso do trabalho desenvolvido por Ricardo Mariano, e cumpre enumerar as razões. Mariano tem a vantagem do tempo. É herdeiro das discussões que o antecederam, e escreve sobre os neopentecostais num momento em que sua expressão na população brasileira já é bastante considerável. Sua obra tem as vantagens de ser inteiramente voltada aos neopentecostais e para tanto propõe critérios bem definidos para separar os pentecostais e os neopentecostais. Nessa tarefa, Mariano se inspira muito na obra de Paul Freston, mas não deixa de atualizá-la. Isso proporciona ao seu trabalho as seguintes preferências que serão abordadas a seguir:

Para além de ter herdado uma literatura sobre o tema, Mariano apresenta seu trabalho com uma abordagem puramente sociológica, e livre de elementos teológicos. Isso lhe permite fazer uma dissecação interessante da teologia pentecostal como um universo simbólico que emerge das origens sociológicas daquele grupo, e não das tradições bíblicas. Apesar de saber da importância de conhecimentos de teologia e de história eclesiástica, o autor está mais preocupado com outra questão. O problema inicial do seu trabalho era entender o surgimento dos neopentecostais - não como um subgrupo dentro do pentecostalismo, mas como um novo grupo independente - e as razões que possibilitaram seu surgimento. Para tal, Mariano estabelece, em um primeiro momento, as singularidades sociológicas que permitiram o desenvolvimento do neopentecostalismo enquanto espírito e prática e, num segundo momento, identificar as mudanças no social que esse espírito-e-prática provocou a posteriori, para determinar também sociologicamente a diferença entre pentecostais e neopentecostais.

Além disso, Mariano propõe um novo modelo para classificação dos neopentecostais, inspirado no modelo das "três ondas" proposto por Freston (que por sua vez, se inspirou em Martin) ${ }^{8}$. Porém o atualiza com dados e centra sua

\footnotetext{
${ }^{8}$ A exceção foi Bertone Souza (2015), que apresentou uma divisão diferente, em duas fases. Sua crítica ao tradicional modelo das "três ondas" se inscreve como uma ressalva à "segunda onda" que, segundo o autor, representou muito mais continuidades do que rupturas com a primeira. Desse modo,
} 
terceira onda num marco temporal mais preciso para marcar o início do neopentecostalismo no Brasil: a fundação da Igreja Universal.

Mariano ainda apresenta duas particularidades finais que me fizeram preferi-lo a outros. Primeira; como situa o surgimento da IURD como marco do neopentecostalismo, Mariano desenvolve considerável parte do trabalho tomando aquela igreja como referência. Segunda; todos os autores que antecederam Mariano tinham algum vínculo, clerical ou não, com alguma denominação (exemplos como Bittencourt e Mendonça, pastores presbiterianos, e Jesús Hortal, padre jesuíta). De certa maneira suas análises sobre o neopentecostalismo e sobre a IURD deixam transparecer algum desprezo teológico pelo tema, ora tratando os neopentecostais como um rebaixamento do espírito evangélico, o que não acontece em momento algum na obra de Ricardo Mariano. Talvez esses fatores expliquem por que sua obra ainda é referência, quase vinte anos depois de publicada.

O trabalho de Mariano foi, portanto, a minha "bússola" para interpretar o neopentecostalismo e a IURD. Além da sua obra sobre os neopentecostais (Mariano, 1999), outros artigos tratando do movimento evangélico, da IURD e da teologia da prosperidade foram coletados e estudados. De literatura mais recente, destaco o livro de Wander de Lara Proença (Proença, 2011), com uma excelente análise histórica da IURD, mas que não explora a inserção daquela igreja na estrutura neopentecostal tão a fundo quanto Mariano. Travei contato também com dissertações e teses universitárias de diversas formações que envolvessem o neopentecostalismo, a IURD ou a análise de educação empreendedora nos quadros da Igreja Universal. Em especial a dissertação de Mestrado de Edson Elias de Morais (UEL, 2013) e as teses de doutorado de Erik Fernando Miletta Martins (Unicamp, 2015) e de Carlos Andrade Rivas Gutierrez (Unicamp, 2017) ajudaram a entender a linguagem usada pela igreja.

Bertone Sousa não ignora uma reconfiguração pentecostal nos anos 50-60, mas não a enxerga como uma inovação relevante no cenário evangélico brasileiro. Prefere, portanto, uma divisão bifásica entre o que chamou de Pentecostalismo Salvacionista, inaugurado no início do século XX, que corresponde, temporalmente, à primeira onda, e o Pentecostalismo de Prosperidade, que corresponde temporalmente à terceira onda. Apesar da originalidade do modelo, optei pela separação trifásica, por não ter a competência acadêmica para analisar o fenômeno como esses autores e também porque o modelo de Sousa parece muito adequado para o trabalho que esse desenvolveu no seu doutorado, mas perde um pouco de sentido no presente trabalho. 
Para que a pesquisa não ficasse somente no campo teórico, procurei participar da Igreja Universal e deixar que ela falasse por si própria. Coletei exemplares da Folha Universal e explorei os veículos de comunicação oficial da igreja. Optei por não frequentar os cultos para não invadir o espaço de oração alheio e não perturbar a liturgia. Além disso, a IURD não costuma receber com bons olhos um pesquisador que não se identifica previamente. Para respeitar a igreja, assisti a cultos virtualmente, pela internet. Selecionei alguns de 2011 a 2018 que me pareceram mais interessantes e cujos trechos transcrevo no trabalho.

Para o estudo do neoliberalismo, o marco teórico utilizado foi a abordagem do fenômeno como uma forma de governabilidade dos corpos e das ações dos sujeitos por um poder que não é somente restritivo, mas também constitutivo. Esse poder assume a forma de uma norma de governo biopolítico, que desloca o governo dos indivíduos para os próprios indivíduos, que passam a governar a si mesmos segundo a norma. Como auxiliar na construção desse marco, o pensamento de Christian Laval, em especial a sua colaboração junto a Pierre Dardot desenvolvida em A Nova Razão do Mundo (Dardot; Laval, 2016) foi extremamente marcante. Os dois autores me pareceram adequados ao estudo do tema porque apresentam uma abordagem muito original e particularmente interessante ao fenômeno neoliberal. Partindo do pensamento marxista clássico, os autores derrubam mitos construídos sob o neoliberalismo que o identificam como a ressurreição do liberalismo clássico, a simples mitigação do Estado ou uma estratégia do capital contra o Estado Social.

Ao fazê-lo, contudo, os autores também evitam tratar no neoliberalismo como um simples espírito do capitalismo - à maneira de Boltanski e Chiapello, e também como uma estratégia pré-ordenada e pré-pensada pelo Capital como extensão da violência e dominação do mundo da vida9 . Para isso, inovam quando classificam o neoliberalismo com o conceito que deu nome ao livro: uma nova razão de Mundo, uma nova forma de governabilidade unindo a política (econômica, estatal, cultural) à Biopolítica nos moldes foucaultianos. No seu trabalho, as obras dos neoliberais alemães e austríacos são dissecadas segundo a análise de Foucault

\footnotetext{
${ }^{9}$ Sobre uma interpretação marxista e o enfoque de Foucault sobre o fenômeno neoliberal, escreve Laval: "Dans son approche, le néoliberalisme n'est pas d'abord consideré comme une phase du capitalisme, à la manière des marxistes. Il releve plutôt d'um certain mode de gouvernement des hommes et de prodution des sujets, et même de l'une des formes et de 'lune des phases de l'invention du sujet moderne comme homme économique." (Laval, 2018, p. 28)
} 
desenvolvida em Naissance de la Biopolitique para evidenciar um novo modelo de sociedade e de governabilidade pautada pela concorrência, pelo cálculo de intervenção governamental e pela educação do Homem-Empresa como unidade de liberdade e de existência. É, portanto, a criação de uma ordem pela educação do sujeito. É a instituição de uma identidade, de modo de vida, de um governo de si mesmo por meio do mercado. É a construção de uma nova subjetividade e a inauguração de uma nova racionalidade governamental. No dizer dos autores: "Essa razão do 'mundo' é global, 'faz mundo' no sentido de que ela atravessa todos as esferas da existência humana sem se reduzir à esfera propriamente econômica" (Dardot; Laval, 2015)

Utilizando outras bibliografias para melhor sedimentar a pesquisa, como o mencionado Foucault e os próprios neoliberais, e partindo do pressuposto de que o neoliberalismo foi produto do acúmulo de experiências, e não um plano préestabelecido pelo Capital onipotente, procurei identificar na Igreja Universal um veículo dessas experiências que possibilitam a formação do sujeito neoliberal. A aproximação entre a identidade neopentecostal, tal como evidenciada a partir de Mariano, e a subjetividade produzida pelo neoliberalismo, brilhantemente estudada por Dardot e Laval enriquecem a pesquisa, e fazem que esse marco teórico seja preferido a outros.

Não ignoro o montante de outros autores e interpretações que se debruçam sobre a questão neoliberal: Boltanski \& Chiapello, Duménil \& Lévy, Pierre Bourdieu, David Harvey, Nancy Fraser, Wendy Brown, Marilena Chaui e Ricardo Torres só para citar alguns ${ }^{10}$, mas suas interpretações foram preteridas, seja em

\footnotetext{
${ }^{10}$ Merece referência especial o tratamento dado ao neoliberalismo por Antonio Negri e Michael Hardt nos trabalhos que mantêm em conjunto. Os dois autores têm uma abordagem interessante do neoliberalismo mas que guarda diferenças com a abordagem de Dardot e Laval. Para uma análise da perspectiva negriano-hardtiana do neoliberalismo por Dardot e Laval, remeto à entrevista dos dois autores assinalada na bibliografia (Dardot; Laval, 2015). Negri também faz uso do termo biopolítico para análise das relações de poder, à semelhança de Foucault, para a análise do neoliberalismo. No entanto, o biopolítico foucaultiano foi uma forma de análise cirúrgica das relações de poder emergentes ao final do século XVIII para melhor compreender o novo modo de se fazer o processo político e, a partir daí, estruturar formas de resistência ao poder biopolítico. Negri transporta o biopolítico para além da "análise", para defini-lo, a partir de Spinoza, como um poder de resistência inerente a toda forma de vida, pois a resistência sempre acompanha a geração potente de formas de vida. Desse modo, o biopolítico foucaultiano é primeiramente um instrumento de análise, enquanto o biopolítico negriano é um instrumento de luta imediata. É uma capacidade imaterial de pensamento e resistência comuns, pois imaterialidade é, por definição, compartilhamento de vida.
} 
função do critério teórico que utilizam, seja em razão do marco intelectual que empregam. Tome-se por exemplo Harvey que, tal como os outros, é um respeitado acadêmico. Sua abordagem é diversa, pois reflete a sua formação de geógrafo. Sua análise parte de um princípio marxista "duro", que pressupõe o neoliberalismo como um novo regime de acumulação pela "despossessão" enfoca aspectos macroestruturais do desenvolvimento do capitalismo em locais como China ou em fenômenos como concentração de renda. Tal abordagem, ainda que não seja incorreta, deixa escapar um aspecto crucial do neoliberalismo que é o seu aspecto governamental, disciplinar, e que se sustenta na construção de um sujeito regido por um autogoverno empresarial, concorrencial e competitivo. Explicar o neoliberalismo como redução do público, desmonte do Estado Social, eventual ideologia burguesa do século XXI ou financeirização da vida ainda são incompletas, segundo Dardot e Laval.

A grande novidade que Dardot e Laval oferecem é resultado de uma ocasião, a saber, a publicação de Naissance de la Biopolitique em 2004, que permitiu uma interpretação inédita do neoliberalismo como um modelo de sociedade que oferece uma nova perspectiva de vida e de governo de si e influenciou os autores na composição da sua obra ${ }^{11}$. Fazendo um cotejo possível entre o pensamento marxista e os traços deixados por Foucault, mas também fazendo sua crítica, os autores detalham o porquê do neoliberalismo ser tratado como uma nova razão de mundo, e por que esse tratamento se sobressai aos outros entendimentos, sem prejuízo dos seus méritos. É na essencialidade da pesquisa sobre o sujeito neoliberal e a abordagem do Neoliberalismo como nova razão do mundo resultante de processos e experiências heterogêneas que a obra de Dardot e Laval se destacam com brilhantismo.

\footnotetext{
${ }^{11} \mathrm{O}$ texto originalmente era o curso de Michel Foucault ministrado no Collège de France entre janeiro e abril de 1979, cujas gravações obtidas foram compiladas e editadas por Michel Senellart. Foi a publicação da obra na França que deu uma nova interpretação ao Neoliberalismo como Biopolítica, além de evidenciar o Neoliberalismo como uma coisa nova, e não como ressurreição ou resgate do Liberalismo clássico. Dardot e Laval, que à época estavam montando um grupo de pesquisa na Université de Paris Nanterre chamado Question Marx?, focado na pesquisa e releitura das perspectivas da teoria marxista da História do Capitalismo, desenvolveram um cotejo entre a pesquisa do grupo e o pensamento foucaultiano para promover a análise do Neoliberalismo consubstanciada em A Nova Razão do Mundo, que foi escrito em 2008 e lançado na França no ano seguinte. A isso seguiram a edição inglesa da obra (2014) e a brasileira (2016). Naissance de la Biopolitique foi lançado no Brasil pela editora Martins Fontes, sob o título Nascimento da Biopolítica.
} 
Um último esclarecimento deve ser feito quanto à escolha e utilização da bibliografia. Sempre que fosse possível e conveniente, utilizei as obras estudadas e citadas em sua língua original. Quando não, privilegiei traduções em outras línguas que eu sabia serem fidedignas. Desse modo, por exemplo, as obras de Walter Eucken foram estudadas em inglês e espanhol porque não domino o alemão. Do mesmo modo, o leitor notará que os dois livros de Michel Foucault utilizados (Nascimento da Biopolítica e Sécurité, Territoire, Population) estão em línguas diferentes por simples questão de conveniência: eu tinha à minha disposição um exemplar da tradução brasileira do primeiro ao mesmo tempo em que tinha um exemplar do segundo no original francês. Também a obra de Jacques Bidet utilizada foi feita a partir da tradução inglesa, que já me era conhecida quando comecei a escrever este trabalho. Naturalmente não sou tradutor, mas garanto que as minhas capacidades de leitura em inglês, espanhol e francês são aptas a me permitir o contato com obras nessas línguas (no original ou em tradução) sem qualquer prejuízo ao seu entendimento e, consequentemente, às suas utilizações neste trabalho. 


\title{
Os Camelos: Definindo Neopentecostalismo
}

\author{
"Hallelujah! Thine the Glory! \\ Hallelujah! Amen! \\ Hallelujah! Thine the Glory! \\ Revive us Again!" \\ 'Revive us Again' ( Hinário Pentecostal Americano)
}

\begin{abstract}
O Dicionário das Religiões da Universidade de Oxford (Bowker, 1997), apresenta a seguinte definição para o verbete pentecostalismo (pentecostals/pentecostalism):
\end{abstract}

Grupos de cristãos que enfatizam a descida do Espírito Santo sobre os apóstolos durante o primeiro Pentecostes (cristão) (Atos, 2), e o contínuo trabalho do Espírito pós-conversão. Os movimentos modernos datam da época do ministério de Charles Parham (1873-1929) nos EUA em 1900 e 1901. Ele associou o batismo no Espírito Santo à Glossolalia (dom de línguas) e vislumbrou a sua atualidade como uma restauração dos dons reservados para os Últimos Dias. Existe, assim, uma forte ênfase escatológica, exaltando a experiência espiritual sobre a reflexão intelectual. Suas características são as formas participativas de louvor - bater de palmas, dança, braços em riste, profecias - e possui grande popularidade e apelação aos pobres e de baixa educação (daí o título do estudo de R. M. Anderson, Vision of the Disinherited, 1979). Dado que a experiência suplanta o Ministério Formal, várias igrejas pentecostais surgiram; e apesar da realização da primeira conferência mundial pentecostal em Zurique, 1947 (com a segunda em Paris, 1949), existe forte oposição à formação de um corpo representativo autorizado a "falar pelos" pentecostais. Há oposição também ao movimento ecumênico, dado que a maior parte das igrejas envolvidas são consideradas em situação de apostasia. Há pelo menos 130 milhões de pentecostais pelo mundo, com rápida expansão verificada na América do Sul. (Em tradução livre)

O dicionário fornece uma descrição resumida e adequada para um verbete. Várias das características mencionadas, como antiecumenismo, atualidade do espírito e liturgia corporal integram de fato o universo do pentecostal. O fenômeno, ou sua apresentação como feita no dicionário, está longe de ser bem estruturada quando o assunto do pentecostalismo é explorado de maneira profunda. Parte disso pode ser atribuída aos seus redatores europeus, para quem o pentecostalismo ainda é religião de "pobre ignorante", cujos desdobramentos da sua realidade social são quase desconhecidos. O maior agravo é notório quando se verifica que o dicionário 
ignora por completo as diferenças entre os Pentecostalismos e seu descendente, o neopentecostalismo, ou pior: ignora o próprio neopentecostalismo como fenômeno independente.

O neopentecostalismo no Brasil demorou, em média, vinte anos, contados do seu surgimento, para começar a ser estudado e ventilado academicamente. Seu surgimento costuma ser identificado no fim da década de 70, mais precisamente em 1977, quando no coreto da Praça do Méier, na Zona Norte Carioca, o Sr. Edir Macedo Bezerra começou uma igreja de origens suburbanas com aspirações universais. Foi somente em 1993, com a publicação de Paul Freston, Protestantes e Política no Brasil: Da Constituinte ao Impeachment, que uma análise do neopentecostalismo brasileiro ganhou uma moldura mais consistente ${ }^{12}$, num momento em que as igrejas neopentecostais já apresentavam estrutura e presença consideráveis no cenário religioso nacional, fruto de um crescimento rápido e sem precedentes.

A publicação de Freston abriu olhos para o gigantesco rebanho de evangélicos neopentecostais formado no então considerado "maior país católico do mundo", e também caminhos para outras abordagens feitas no campo da sociologia da religião e da teologia para tentar classificar o fenômeno religioso como um todo: das origens sociais dos fiéis, passando pelo histórico institucional à genealogia da liturgia.

Para o presente trabalho, contudo, antes de adentrar à história e surgimento do neopentecostalismo no Brasil e as suas classificações, traço uma perspectiva do cenário religioso do mundo entre o final década de 1970 e os dias atuais, em breve síntese. Por dois motivos: primeiro, porque foi nesse período que se verificou o desmantelamento do Estado Social e a inauguração dos primeiros governos que

\footnotetext{
${ }^{12}$ Freston não foi o primeiro, todavia. Antes disso já havia análises sobre as novas manifestações evangélicas no Brasil, mas ainda bastante vinculadas ao pentecostalismo clássico e ao deuteropentecostalismo (terminologias que serão exploradas mais à frente). Nesse sentido, é importante lembrar das obras de Beatriz Muniz de Souza; Carlos Rodrigues Brandão, Antônio Gouvêa Mendonça, José Bittencourt Filho e Jesús Hortal Sánchez, que foram pioneiros na empreitada de uma tentativa de classificação entre as chamadas "primeira" e segunda "ondas" pentecostais, mas ficam carentes quanto a uma análise aprofundada do neopentecostalismo, além de estarem presas à terminologia classificatória norte-americana (caso de Beatriz Muniz Souza), entre outras questões metodológicas. O livro de Freston é marcante pois inovou no modo de como se olhar para o fenômeno neopentecostal como uma coisa nova, sem ser uma "degeneração" do pentecostalismo clássico.
} 
seriam chamados de neoliberais. Segundo, porque é também nesse intervalo histórico que se pode identificar uma intensificação no cenário de globalização que acompanhou essa mudança, e que está inscrita numa estrutura maior; a saber: as transformações do próprio capitalismo, que passa de uma feição industrial e produtiva a um contorno mais financeirista e consumerista. Tal processo de globalização, conjugado com as transformações referidas, inovou consideravelmente no palco religioso, conforme se verificou no novo rol de manifestações de espiritualidades cristãs - em denominações tradicionais ou não -, judaicas e nas novas crenças egressas das matrizes religiosas orientais. Por isso, o primeiro ponto que se pretende expor é situar o surgimento do fenômeno neopentecostal na configuração religiosa que emerge desse contexto (e seu surgimento no Brasil) para, partindo disso, se analisar a Igreja Universal do Reino de Deus sob uma ótica mais bem determinada.

\section{1}

\section{Religião no século XX e os limites de uma teoria da secularização}

Um passo a ser abordado na análise do horizonte religioso globalizado foi a decadência da ideia de um processo de secularização, intrínseco à ideia da modernidade, que nas suas origens buscava romper a moldura teológica de organização da vida, da moral e da política. Nesse cenário, a expectativa da substituição dos valores teológicos e religiosos por uma nova metafísica que, apesar de não necessariamente expulsar o divino, o despia de toda a magia e o vestia com traços racionais, tendia a esperar na sociedade um abandono da forma religiosa e a adoção de outras formas de racionalidade governamental. No século XX, foi Peter L. Berger (1929-2017) quem sustentou por muito tempo a ideia de uma secularização da sociedade.

Mas Berger, em artigo de $2001^{13}$, voltou atrás e disse que tudo o que havia pensado sobre a secularização e um eventual desencantamento do mundo era fruto de considerações equivocadas, e ressaltou: “O mundo não está menos religioso que antes. Está mais religioso ou, no mínimo, tão religioso quanto antes" (Berger, 2001). Nesse artigo, Berger elucida vários dos fatores que o levaram ao erro, bem

\footnotetext{
${ }^{13} \mathrm{O}$ artigo de Berger, de título "A dessecularização do mundo: uma visão global”, foi publicado na Revista Religião e Sociedade (ISER), v. 21 (2001), pp. 7-23. Tradução de Henry Decoster.
} 
como os sintomas que comprovam que o mundo não está nem um pouco menos religioso. Entre os fatores invocados para justificar o erro, Berger elucida: 1) o fato de as pesquisas sobre religião ainda estarem muito vinculadas às religiões ocidentais, muitas vezes ignorando as orientais; consequentemente, 2) o fato de as pesquisas, no tocante ao cristianismo, ainda orbitarem muito em torno das igrejas tradicionais, ignorando a explosão de novas liturgias herdeiras do espírito evangélico, especialmente na chamada "modernidade periférica" e, por fim, fazendo quase um mea culpa de classe, Berger acusa os estudiosos e acadêmicos estudantes da religião ou de outros assuntos - de se esquecerem de que vivem em um ambiente tipicamente racional, crítico e não-religioso, e de nessa lógica tomarem a parte pelo todo, e de ignorarem que o mundo alvo e desencantado da pesquisa acadêmica não é em nada semelhante ao mundo real, que é passional, imaginativo e (sempre foi) religioso.

A revisão da secularização proposta por Berger parte da própria ação secularizante da modernidade sobre as religiões, fazendo com que essas fossem obrigadas a escolher abraçar ou combater a modernidade: modernizar-se ou recrudescer-se ainda mais no núcleo duro e dogmático dos valores religiosos. Curiosamente, Berger explica que as religiões que se "modernizaram" acabaram por entrar em crise de valores (ou de fiéis), com casos mais ou menos graves. Notoriamente, o maior exemplo de modernização nessa conjuntura foi o Concílio Vaticano II (1963-1965), que veio para resgatar na Igreja algo que ela mesma perdeu: os fiéis, e abrir a vida eclesiástica à participação destes. Tal ação teve um efeito colateral, ao evidenciar a crise dos valores católicos tradicionais, que de repente tiveram que dividir espaço com os novos valores, as novas práticas e as novas liturgias. De repente o canto gregoriano teve que dividir espaço com o Padre Zezinho.

Aos que não aceitavam de forma alguma as inovações do concílio restava a segunda opção: obstinar-se. Não modernizar-se. Eliminar o novo para proteger o velho. Assim surgiram as cisões de grupos católicos tradicionalistas, os quais alguns permaneceram no seio da Igreja enquanto outros se separaram, ao exemplo da Fraternidade Sacerdotal de São Pio X - FSSPX e outros segmentos sedevacantistas pós-concílio. Outros grupos não clericais ganharam aspectos sectários, como a Sociedade Brasileira de Defesa da Tradição, Família e Propriedade, a conhecida 
$\mathrm{TFP}^{14}$. Semelhantes processos aconteceram no judaísmo, contrários ao judaísmo liberal e também no islamismo, como alternativas aos efeitos da modernização no universo muçulmano.

O ponto que Berger quer levantar é que o processo de secularização e modernização das religiões tradicionais, longe de promover um desencantamento do mundo, promoveu de certo modo o oposto: a ação secularizante projetou uma reação em defesa dos valores religiosos tradicionais postos sob a mira do fogo. Ao antirreligioso contrapôs-se um religioso indignado, afirmador de dogmas e, portanto, repaginado com um retorno aos princípios, ao fundamentalismo. Assim, a modernização secularizante acabou tendo o efeito oposto do esperado: enquanto as grandes religiões subordinaram-se à modernização, os indignados formaram novos focos, que são pequenos em número de fiéis se comparados às confissões predominantes; mas que têm a grande capacidade de cooptação de novos adeptos, carentes de sentido à vida ou até mesmo embebidos de um espírito saudosista dos velhos hábitos e das velhas verdades sobre as novas.

Se Berger tem razão quando diz ser um mito a secularização capitaneada pela modernidade, e o mundo não está menos religioso, ou pelo menos está tão religioso quanto sempre foi, então como se explicam as transformações que o fenômeno religioso sofreu nos últimos 50 anos que, se por um lado pareceram indicar a ideia de um mundo "menos religioso", por outro lado testemunharam a gênese de várias novas manifestações religiosas ou espirituais? Que ligação poderia haver entre as metamorfoses de um capitalismo neoliberal pós-industrial e consumerista com o surgimento das novas manifestações e interpretações religiosas?

Uma interessante reflexão de cotejo entre as transformações do capitalismo, envolvendo a transferência do seu núcleo do industrial para o financeiro na circunstância da ascensão neoliberal, e a explosão de novas manifestações

\footnotetext{
${ }^{14}$ A TFP foi fundada em 1960, em São Paulo, por Plínio Corrêa de Oliveira (1908-1995), líder da Direita Conservadora Católica, deputado da Constituinte de 1934 e Presidente da Ação Católica. A Sociedade entrou em processo de declínio após a morte do seu fundador, por questões de sucessão na liderança. Assim surgiram o Instituto Plínio Corrêa de Oliveira e a Associação Privada Arautos do Evangelho, fundada por João Scognamiglio Clá Dias, pupilo de Plínio, e que é reconhecida pela Igreja como ordem religiosa. Também merece menção a Associação Cultural Montfort, fundada por Orlando Fedeli em 1983 como uma dissidência da TFP.
} 
religiosas das mais variadas naturezas, pode ser encontrada no trabalho desenvolvido por François Gauthier e outros autores na obra Religion in the Neoliberal Age (Gauthier; Martikainen, 2013), na qual é proposta uma nova forma de se pensar a relação entre o religioso e o econômico para além das teorias clássicas marxista e weberiana da religião, e atualizar o debate entre as mudanças de comportamento religioso promovidas pelas mudanças no comportamento econômico para o século XXI. Conforme se desprende do título da obra, o principal escopo de análise está inscrito na ascensão do neoliberalismo, e toma como marco temporal as últimas quatro décadas.

$\mathrm{Na}$ introdução, os autores destacam a polêmica girando em torno da secularização, e a descartam como horizonte explicativo (ou como único horizonte explicativo) da situação da religião nas sociedades atuais, sem abraçar, contudo, o diagnóstico de Berger. Segundo o trabalho desenvolvido, a teoria da secularização perde força diante do cenário de globalização e consumerismo, com a escalada de um capitalismo pós-fordista e modificação nos perfis do controle do tempo e do trabalho, da emersão de novas identidades e da repaginação do perfil de consumo e das relações sociais da sociedade de massa. De certo modo, nesse cenário globalizado e reconfigurado, a ideia de secularização (que, cumpre reforçar, foi construída nos moldes ocidentais) se via muito atrelada ao binarismo religião $\mathrm{x}$ sociedade inscrito num determinado espaço: o país/Estado/região que, com o advento dos novos tempos, teve suas fronteiras e limites permeados pela globalização, fazendo com que as mudanças comportamentais verificadas religiosas e não-religiosas - se devessem mais a fatores externos àquela comunidade do que a fatores internos, a saber, a educação iluminista, o desencantamento, etc.

Cumpre investigar então, segundo os autores, o âmbito das mudanças introduzidas pelo capitalismo globalizado, pós-fordista, as razões da mudança no perfil de relações entre a realidade econômica e a realidade religiosa.

Em primeiro lugar, o novo painel de produção mudou de matriz e de forma. Com a passagem de um capitalismo industrial para um capitalismo financeiro, o modo de controle dos corpos, do tempo e da vida mudou também os parâmetros comportamentais. Nominalmente, a flexibilização da jornada de trabalho, a 
substituição do perfil salarial da remuneração por um perfil de "rendimento pessoal" e o alargamento do trabalho imaterial. Este último acaba ganhando o predicado de "trabalho intelectual", e envolve o domínio de uma técnica, um savoirfaire, uma expertise; o aprimoramento, em suma, de uma determinada habilidade como acumulação de "capital humano". Daqui já se podem extrair alguns sintomas do "empreendedor de si mesmo" comandado pelas normas de competência e concorrência que, junto a outras características, qualificarão o homem neoliberal do qual se pretende tratar mais à frente.

Em segundo lugar, as novas formas de trabalho produzem um novo segmento social dentro da classe trabalhadora: uma classe que vive do próprio trabalho, que supostamente regula o próprio tempo, o próprio ritmo e a própria produção e cuja manifestação de potência se realiza no consumo. O próprio consumo, associado ao poder aquisitivo, passa a ser o propulsor da identidade social. Uma parcela considerável do público da IURD se insere nessa categoria e comunga da simbologia do consumerismo na esfera do religioso.

Em terceiro lugar, a nova configuração de vida, produto das transformações desse modo de produção capitalista, provoca o universo do simbólico a refletir a realidade do sujeito e as suas aspirações ontológicas. Se os velhos símbolos, as velhas práticas e as velhas liturgias das religiões egrégias não mais oferecem resposta, consolo, esperança ou sentido aos novos sujeitos emersos do novo mundo pós-fordista, ou estes, de alguma forma, não se veem mais representados naqueles, fundam-se outros signos e outros valores religiosos para suprir a lacuna. Tomando a perspectiva cristã como exemplo, dificilmente uma rejeição da riqueza, como à maneira franciscana, seria uma espiritualidade adequada a uma mundividência construída sobre o consumo, como é a atual.

Dessa reflexão, Gauthier apresenta as respostas dos sociólogos da religião às novidades propostas pelas transformações, elencando-as nas seguintes interpretações.

Uma primeira forma de se encarar as transformações sofridas pelo universo do religioso em razão dos novos tempos encara com certo pessimismo o derretimento dos valores religiosos tradicionais e a crise que martela as grandes religiões, e os subscreve sob um denominador negativo. Gauthier e Martikainen se 
apoiam nos trabalhos de sociólogos contemporâneos da religião, como Daniel Bell e Françoise Champion para apresentar as novas manifestações religiosas ou como cópias fracassadas, mutiladas e incompetentes das grandes religiões históricas, ou de proclamar a morte das religiões históricas e inaugurar a era da espiritualidade (com certo cinismo no uso do termo), dando especial atenção às espiritualidades consumeristas, que segundo Champion, seriam rasas em base moral, espírito congregacional e transformariam o espiritual em mercadoria a ser consumida. Os valores religiosos tradicionais seriam destronados e reformados para espelhar as necessidades consumeristas ou identitárias de uma sociedade moralmente espúria ${ }^{15}$.

Outra forma de se pensar as mudanças no campo religioso consiste em observá-las de modo mais neutro, no sentido de não emitir um juízo de valor sobre as transformações, mas de simplesmente verificar as mudanças e identificar suas consequências. O capitalismo e suas inovações não seriam fonte de depreciação do religioso, mas tão somente transformadores do religioso. Esta interpretação, capitaneada por Wade Clark Roof, Jörg Stolz e pelo já citado Peter Berger, compartilha com a primeira a noção de mudança no perfil religioso como consequência da mudança do perfil capitalista, e atribui à nova configuração religiosa uma configuração que se espelha na do mercado, mas sem emitir valor depreciativo, como Champion fez, e nem ser saudosista das grandes religiões como Bell. Antes, conforme Roof, o campo religioso se apresentaria como "um mercado espiritual”. Mas o mercado do qual Roof fala não é o mercado de Champion, onde as religiões e valores espirituais se transformam em commodities para serem consumidas. O mercado de Roof deve ser entendido como o ambiente da escolha racional, no qual o indivíduo dispõe de um cardápio de credos e de opções para escolher uma (ou nenhuma). Esse mercado contempla as velhas religiões, mas abre considerável espaço para toda forma de inovação criativa pós-moderna, nas quais os valores de religiões ocidentais se misturam ao de religiões orientais ou primevas, que eventualmente tomam emprestado uma mítica $\mathrm{X}$ combinada com uma prática Y. Isso explicaria o surgimento dos movimentos new age, ou dos neopaganismos

\footnotetext{
${ }^{15}$ Uma crítica que vincula o desaparecimento dos valores tradicionais e morais da sociedade à crise do sentimento religioso também pode ser encontrada além da Sociologia da Religião. Na literatura, dois autores que, de certo modo, subscrevem a decadência da religião como causa da decadência do espírito humano (e vice versa) são T. S. Eliot (em Notes toward a Definition of Culture) e Mario Vargas Llosa (em La Civilización del Espetáculo)
} 
em voga. A pulverização e generalização de valores religiosos desumbilicados das suas tradições originárias, espalhados por um mundo globalizado de uma sociedade de massa talvez ajude a entender por que Berger reviu sua teoria de declínio da religião.

Uma crítica pode ser feita a essas duas teorias. Se a primeira acerta, de alguma forma, na identificação da expansão do capitalismo pós-fordista e na globalização como as causas de um certo derretimento das velhas religiões, "pecam" quando se deixam invadir por um sentimento de saudosismo melancólico e mal-estar. Se acusam o sucateamento da forma religiosa, que foi esvaziada de moral e transformou-se em simples mercado espiritualizado, não conseguem enxergar qual é a explicação de cunho social que sustenta esse "mercado". Em outras palavras, não conseguem indicar nem por que a globalização e a transformação capitalista provocaram tais mudanças na paisagem religiosa, e nem conseguem entender os motivos e mecanismos que alimentam as novas manifestações. Indicam um sintoma e se lamentam em cima dele, sem oferecer diagnóstico. Seu apreço pelo antigo e pelo tradicional, sua incompreensão do presente e sua aparente aversão ao novo parecem mostrar que os que subscrevem essa interpretação possivelmente se inscrevem em quadros conservadores.

A segunda teoria, se não apresenta teor julgador ou conservador, recai em outro vício da primeira, pois parece desconhecer as causas que levam ao sustento do novo perfil religioso. Quando afirma a inscrição do horizonte religioso contemporâneo num painel de "mercado enquanto gama de opções", operado por indivíduos equipados com a escolha racional, tal teoria parece ignorar aspectos substanciais da forma religiosa (a saber, o seu escopo místico, psicológico e inconsciente, que passa longe do juízo racional), e que, se compartilha com a primeira teoria a visão de que a expansão da globalização e do capitalismo pósfordista são os responsáveis pelas mudanças investigadas, não consegue explicar qual é a razão do novo ambiente social e econômico que possibilita a sobrevivência dessas novas religiões. Além disso, ao construírem seu raciocínio em um jogo de "mercado" e "escolha racional", os defensores da segunda teoria ainda parecem presos à perspectiva europeia e ignoram uma gama enorme de manifestações religiosas de outros lugares que são novas, mas que ainda estão presas a concepções tradicionais como família, misticismo, magia (a exemplo do pentecostalismo), 
fazendo com que a religião seja um fator a priori de construção da subjetividade do indivíduo, e não o contrário, o sujeito racional como avalista a posteriori de uma determinada religião.

A essas duas correntes se apresenta uma terceira, que apesar de não negar às correntes anteriores alguma plausibilidade quanto à mudança no perfil religioso e nas suas causas capitalísticas, introduz um novo marco sociológico a ser estudado, e sob um novo marco teórico. Trata-se de observar, sob a égide das transformações provocadas pelo Capitalismo pós-industrial e pela Globalização, o surgimento das "Religiões da Prosperidade" (“Prosperity Religions"). Essa toponímia, ao invés de incorporar novas religiões, diz respeito a novas manifestações religiosas dentro das grandes religiões - não só o Cristianismo, mas também o Budismo e o Hinduísmo, mas que possuem um condão de uma nova ética: a ética dos valores de produção ("production values").

As religiões de prosperidade se desenvolvem dentro de uma perspectiva mais tradicional, de maneira que não têm de inventar uma nova mitologia, mas implicam numa reformulação de valores dentro do âmbito religioso. Sua essência constitui uma nova ética religiosa - o que envolve condutas morais, litúrgicas e comunitárias próprias. Gauthier e outros não escondem onde querem chegar quando tratam do maior exemplo de religião da prosperidade dentro do cristianismo: o pentecostalismo (enquanto gênero, cujas espécies serão tratadas mais à frente).

Essas novas manifestações religiosas, por se desenvolverem no seio de religiões tradicionais, se apresentam como um movimento de resistência aos efeitos da secularização e do desencantamento do mundo religioso para resgatar aquilo que se perdeu: a prática religiosa. Com o desencantamento, a religião perdeu o seu papel centralizador da vida como promotora de significados. A ideia das práticas religiosas tradicionais, como o jejum, a guarda dos dias santos e a penitência, para citar exemplos cristãos, foi esvaziada de sentido por outras formas simbólicas, de modo que a religião estaria legada a um catálogo moral para se ensinar às crianças, e a igreja era um clube que as pessoas frequentavam nas manhãs de domingo.

Cumpria, pois, ressignificar o mundo e o religioso por meio da prática. Mas essa ressurreição da prática religiosa não é um retorno aos princípios: é uma reinvenção, revaloração, ressignificação. Se algumas práticas são vetustas, como o 
jejum e o retiro, outras são novas, como a glossolalia e os exorcismos, que apesar de aparecerem em passagens bíblicas, são práticas incomuns nas igrejas tradicionais.A nova ética incorpora outros meios simbólicos. O corpo do crente é marca da sua fé e atestado do seu testemunho: é a vestimenta, a conduta, o gesto, o vocabulário e o próprio corpo, que quando está "cheio de espírito" ou "possuído" apresenta comportamentos incomuns. Assim destaca-se que o resgate do religioso não se limita ao espiritual e à prática espiritual, mas também ao corporal, à prática corporal e ao universo material

Esse resgate e ressignificação do religioso pelo espiritual e material implicará na ressignificação da salvação e da danação, que também serão espirituais e materiais. Em conclusão, essa terceira interpretação das mudanças religiosas provocadas pela globalização e pelo capitalismo contemporâneo seriam o aparecimento de grupos específicos dentro das grandes religiões, que teriam por marca uma resistência à secularização, ao relativismo e ao discurso modernizador, e que promoveriam uma nova ética religiosa, pautada sobre o resgate e a ressignificação de valores e práticas tradicionais, contribuindo assim para o ressurgimento do mágico e do fantástico - seja divino ou diabólico - dentro do ambiente religioso. A salvação ou a condenação se conquistam por meio da conduta, da prática e da manifestação espirituais e materiais do sujeito. Isso acarreta numa nova visão soteriológica: a salvação também tem caráter material.

Uma abordagem pentecostal do cristianismo nesse sentido pode ser feita a partir dessa última interpretação apresentada, principalmente no tocante à ressurreição do mágico no ambiente religioso e do corpo como marco de manifestação simbólica. Uma abordagem neopentecostal ${ }^{16}$ iria mais além, incidindo de maneira mais profunda no núcleo duro da questão da "prosperidade" e

\footnotetext{
${ }^{16}$ Gauthier, quando trata das Prosperity Religions, faz imediata relação com o "pentecostalismo" ("pentecostalism", GAUTHIER, 2017, p. 9). Cumpre advertir, todavia, que apesar de existir a palavra neopentecostalism, não há, na língua inglesa, o hábito de diferenciar morfologicamente o Pentecostalismo do neopentecostalismo, ambos atendendo por pentecostalism. Para se referir ao Neopentecostalismo outros termos, como mega-church ou prosperity Faith são usados. neopentecostalism era utilizado para se referir às igrejas pentecostais mais recentes, e hoje é um termo já em desuso na terminologia norte-americana. No livro citado, fica evidente que Gauthier e os outros autores estavam querendo chamar a atenção para o fenômeno neopentecostal quando falaram que as Prosperity Religions tinham no "pentecostalismo" o seu maior exemplo, posto que no Brasil, conforme se explorará adiante, o chamado Pentecostalismo tem como uma das suas marcas o desprezo, a negação ou o desinteresse pelos bens materiais e seculares, dificilmente se encaixando no conceito de uma "religião de prosperidade".
} 
da materialidade, e, explorada à luz da ascensão neoliberal, explicaria melhor a relação entre fé e consumerismo que caracteriza o indivíduo neopentecostal.

Mas antes de entrar nesse ponto, cumpre explicar melhor o que se entende por Pentecostalismo e o que se entende por Neopentecostalismo. No processo de diferenciação entre os dois, até para determinar quão pentecostal o neopentecostalismo é (ou não é), é preciso explicar melhor as circunstâncias históricas do surgimento de cada uma delas, o segmento social no qual se desenvolveram, e também as sutilezas dos seus processos de expansão e missão, bem como os seus pilares teológicos. É o que se passa a explicar.

\section{2}

\section{Do pentecostalismo ao neopentecostalismo: as ondas pentecostais}

Definir pentecostalismo, neopentecostalismo e estabelecer as diferenças entre eles apresenta algumas dificuldades iniciais. Em parte porque tanto os pentecostais quanto os neopentecostais não são uma igreja específica, como a católica, a luterana ou a presbiteriana; e também porque não se identificam como um ramo teológico específico, como os calvinistas, os anabatistas e os metodistas. Talvez a palavra que os melhor definiria - e ainda assim longe de definir coisa alguma - é movimento. Pode-se dizer que são evangélicos, e que se classificam como pentecostais ou neopentecostais não por valores dogmáticos, mas antes por práticas (de culto, de pregação, de proselitismo) e pela sua relação com o mundo; isso é: com tudo aquilo que não compõe o universo da Igreja; o resto. Isso quer dizer que uma igreja pentecostal não vai se classificar como "pentecostal". Vai preferir se identificar como "evangélica" ou "cristã". As suas práticas, a sua liturgia, a sua organização eclesiástica é que vão estabelecê-la como integrante ou não no frame pentecostal. Ser pentecostal é, portanto, uma prática, inscrita em um quadro de valores que, para além de critérios de classificação religiosa, produzem uma identidade.

Mas só a prática não basta para melhor delimitar esses grupos. Cumpre aprender a sua História. Existe a vasta literatura do início dos anos 80-90 sobre a construção do pentecostalismo e do neopentecostalismo brasileiros. (Martin; 
Freston; Almeida et al.), e também trabalhos mais recentes ${ }^{17}$. E apesar de existir certo consenso quanto a algumas práticas pentecostais e neopentecostais, há discrepância. O mesmo se verifica no momento da reconstrução do percurso histórico do pentecostalismo no Brasil que desembocará no Neopentecostalismo. Para este trabalho, conforme expresso na parte metodológica, decidi adotar o modelo proposto por Ricardo Mariano (1999) para a classificação das igrejas pentecostais e neopentecostais brasileiras, separando o fenômeno pentecostal (como um todo) em três "ondas".

Feitas as considerações a respeito da metodologia mais acima, passo a esboçar um breve histórico do pentecostalismo no Brasil ${ }^{18}$. Meu objetivo nessa etapa é estabelecer um traçado histórico que começa no aparecimento da primeira denominação pentecostal no Brasil e termina com o estabelecimento e concretização da Igreja Universal do Reino de Deus que, seguindo Mariano, tomo como o grane marco do neopentecostalismo no Brasil. Daí em diante explorarei a IURD nas suas práticas, o que cumpre dizer, a sua liturgia, seu modo de organização e seu "programa de salvação", mas sempre sob o prisma do neopentecostalismo.

$\mathrm{O}$ pentecostalismo aparece no Brasil no início do século $\mathrm{XX}$, com a fundação da primeira Congregação Cristã (depois Congregação Cristã no Brasil CCB) em 1910, por Luigi Francescon na cidade de São Paulo. No ano seguinte, dois missionários suecos "recebidos no segundo batismo" fundaram a primeira das Assembleias de Deus (AD) em Belém do Pará. Essas duas igrejas, que tinham origem nos Estados Unidos da América, eram marcos do espírito pentecostal. Sua origem na árvore de denominações cristãs encontra raízes no movimento de santidade (holiness), endêmico à cultura religiosa norte-americana e, mais além, no metodismo wesleyano, na Inglaterra do século XVIII ${ }^{19}$ (Martin, 1990, p. 27). Seu

\footnotetext{
${ }^{17}$ Faço referência a alguns trabalhos de qualidade que pesquisei para a realização do presente, em especial a dissertação de Mestrado de Edson Elias de Morais (UEL, 2013) e as teses de doutorado de Erik Fernando Miletta Martins (Unicamp, 2015) e de Carlos Andrade Rivas Gutierrez (Unicamp, 2017). Também o trabalho de Wander de Lara Proença (2011), que apesar de voltado para a Igreja Universal do Reino de Deus, faz uma boa apresentação da história do evangelismo brasileiro.

${ }^{18}$ Para o estabelecimento histórico do pentecostalismo em relação ao protestantismo histórico, em especial no tocante aos movimentos metodista e de santidade, utilizei os trabalhos de Freston (1990) e de Proença (2011).

${ }^{19} \mathrm{O}$ metodismo é tratado na eclesiologia norte-americana como a segunda de três ondas protestantes, antecedida pelo Calvinismo puritano e sucedida pelos Pentecostais clássicos. Curiosamente, foi a
} 
desenvolvimento inicial se deu entre as camadas mais pobres das populações paraense e paulistana, tradicionalmente marginalizadas da presença do Estado e da igreja católica, dominante no Brasil $^{20}$. Sua capacidade de diálogo com as camadas populares e de pouca escolaridade foi um fator crucial para sua penetração e estabilização no país. Tais denominações mantinham uma política governamental congregacional e, no início da sua atuação, a Assembleia de Deus ainda estava vinculada à sua Igreja-mãe nos Estados Unidos, enquanto que a $\mathrm{CCB}$, que cresceu consideravelmente entre a comunidade italiana do Brás graças ao ministério de Francescon, ainda manteria o italiano como principal língua da liturgia até os anos 40.

A essas duas denominações - CCB e AD - e a outras minúsculas que surgiram a partir dessa, Mariano chama de pentecostais clássicos, que teriam dominado o cenário do pentecostalismo no Brasil entre 1910 e $1950^{21}$.

Às características principais do pentecostalismo, as três primeiras que devem ser enumeradas são a introdução do mágico, a guerra espiritual e o desprendimento do mundo, que estão intimamente ligadas. É importante ter essas três características fundamentais bem explicadas para evidenciar a considerável mudança semântica que sofrerão no neopentecostalismo, mais à frente.

partir da ideia dessas três ondas que Freston teorizou seu modelo para explicar as três ondas pentecostais no Brasil. É possível encontrar no Metodismo alguns traços que, desenvolvidos, marcarão o Pentecostalismo, como a ênfase na necessidade de conversão, a ética disciplinar, o testemunho pessoal, a expressividade corporal e sentimental marcante nos cultos e o uso marcante de hinários durante a liturgia. Teologicamente, o Metodismo desenvolveu-se em dois ramos, o chamado "Metodismo Calvinista" de George Whitefield, e o "Metodismo Arminiano", também chamado de Wesleyano, de John Wesley. Foi desse segundo que se podem extrair algumas das marcas que poderiam ser classificadas como proto-pentecostais.

\footnotetext{
20 À guisa de esclarecimento histórico, os protestantes se radicam no Brasil entre o fim do Império e o início da República. A primeira grande igreja protestante estável no Brasil foi a anglicana, com o estabelecimento da Egreja dos Inglezes no Rio de Janeiro em 1816. Ao longo do império, a igreja luterana chegou com os imigrantes alemães e se estabeleceu com presença nas grandes colônias alemães no Sul e nas serras fluminenses. Em 1862 foi fundada a primeira comunidade presbiteriana do Rio de Janeiro e, 1888, construída a primeira catedral metodista, também no Rio de Janeiro. Antes disso, houve presença protestante na França Antártica e na Nova Holanda, mas que não sobreviveram ao fim dessas experiências.

${ }^{21}$ Cumpre fazer duas observações acerca da Soteriologia das duas igrejas. A CCB apresenta um viés determinista, pré-destinatório, que remete à doutrina do Calvinismo clássico, enquanto que a $\mathrm{AD}$ professa uma doutrina de salvação com raízes que remontam ao Arminianismo, e por isso se enfatiza tanto o segundo batismo e a ideia de renascimento para Cristo.
} 
A introdução do mágico é a reconfiguração simbólica dos valores espirituais e históricos do protestantismo e que caracterizam o pentecostalismo como presença imanente, perpétua e atuante do espírito santo. Esse elemento é a pedra chave sobre a qual o pentecostal, evidente pelo próprio nome ${ }^{22}$, se funda. Ser pentecostal é acreditar na atemporalidade do Espírito, de maneira que Deus não muda o seu tratamento no curso da História; por isso, com frequência o versículo da carta de Paulo aos hebreus é frequentemente invocado: "Jesus Cristo é o mesmo ontem, hoje e para sempre!" (Hebreus, 13: 8). O mesmo Espírito que fez andar o paralítico, ver o cego, curar o leproso e ressuscitar os mortos não muda. Ele inspira o seu Povo e realiza o impossível. Deus opera milagres nas vidas dos seus filhos por meio do espírito santo. Por isso, o ingresso do neófito na comunidade se dá pelo seu "batismo no Espírito" ou "segundo batismo", que compreende uma confissão pública dos pecados, a aceitação de Jesus Cristo como messias e salvador, e o renascimento pela água do batismo e fogo do Espírito.

A figura do espírito santo aparece, portanto, como viga mestra que justifica a inseparabilidade entre Deus e a sua Igreja. As manifestações do espírito são constantes, miraculosas, e marcam a fé. Deus cura doenças e alivia dores. Consola os sofrimentos psicológicos e resgata a ovelha desviada como acolhe o filho pródigo. Não existem limites ao seu poder e os cultos pentecostais enfatizam o fator miraculoso com frequência: cantos em uníssono, manifestações histéricas, testemunhos intensos e a presença marcante da massa de fiéis que lotam a igreja balbuciando salmos com mãos em riste e executando a música frenética e ritmada, não raro acompanhada de dança que caracteriza o culto pentecostal. A manifestação espiritual que marca os pentecostais é a glossolalia, ou capacidade de se falar em línguas desconhecidas por intermédio do Espírito, tal como em Pentecostes. O espírito santo operando seus milagres classifica a magia do pentecostalismo. Ele cura, regenera, ensina, manifesta, eleva, constitui, potencializa, determina, salva, emancipa.

\footnotetext{
${ }^{22}$ Alusão ao episódio bíblico do Sopro de Pentecostes, descrito no livro dos Atos dos Apóstolos, 2, que conforme a tradição, o Espírito Santo de Deus, na forma de línguas de fogo, baixou sobre os apóstolos reunidos no cenáculo, cujos corpos repletos de Espírito passaram a manifestar dons, entre os quais o de falar em outras línguas. Pentecostes é o marco do surgimento da Igreja Cristã, e enfatiza a presença de Deus na Igreja e a sua vocação missionária. "Ide por todo o Mundo; e pregai o Evangelho a toda criatura" (Marcos, 16: 15).
} 
A segunda característica, a guerra espiritual, é consequência da magia pentecostal e promove uma reconfiguração do mundo como um ambiente extremamente polarizado, campo de uma batalha perene entre o bem e o mal, Deus e o diabo, salvação e danação. Em suma: Entre o divino e o mundo. A guerra espiritual é constante, e seu fim chegará com a volta de Cristo para o arrebatamento e o dia do juízo - a escatologia é tema constante no universo evangélico pentecostal. É por intermédio da guerra espiritual que os pentecostais (e os neopentecostais depois deles) ressuscitam um personagem que fora paulatinamente varrido do cenário teológico: o diabo. A figura do diabólico deixa de ser simples simbologia do mal ou adverso e volta a ser elemento ativo na luta constante contra Deus. Abandona-se a velha teologia liberal dessacralizada e desmagificada, fruto da secularização, para trazer de volta o diabo vivo, fonte do mal absoluto, para a frente de batalha.

É interessante notar que não existem espaços vazios ou neutros nessa batalha: a guerra é lutada por Deus e seus anjos contra o Demônio e seus anjos caídos no espaço etéreo, porém suas consequências são sentidas também no mundo material, de modo que todo o mal que aflige a vida do crente é obra de Satanás e seus servos; a pobreza, a doença, a miséria, a solidão e a carestia são sinais materiais da ausência de Deus, e presença , portanto, do Demônio. A guerra espiritual obedece à lógica "Quem não está comigo está do lado do inimigo e vice-versa", de maneira que o homem deve escolher entre Deus e o Diabo. Escolhendo Deus, deve fazer o rito de passagem pentecostal: confissão de pecados, aceitação de Jesus e batismo no Espírito, dado que esse, em razão da sua presença e constância, é a arma que o crente dispõe para enfrentar ou afugentar o Diabo. Nessa seara, todos os inimigos de Deus são combatidos: os inimigos afetivos, como o jogo, o vício, a libertinagem; os inimigos institucionais, como a maçonaria, a academia e o Estado $^{23}$; e os inimigos espirituais, autênticos representantes do diabo no mundo: a igreja católica e as religiões de matriz africana.

\footnotetext{
${ }^{23}$ Nem sempre a figura do Estado desponta como inimigo do Povo de Deus na mundividência pentecostal. Cumpre lembrar algumas situações específicas nas quais a população evangélica guerreou contra o Estado. Wander de Lara Proença lembra, por exemplo, a ocasião da Revolta da Vacina no Rio de Janeiro (1904), quando o então tímido agrupamento pentecostal da capital federal se rebelou contra a instituição da vacina pois se acreditava que os assuntos de saúde eram de competência do divino, e não do Estado, que não deveria se intrometer. Outros casos interessantes, e que dividem pentecostais e neopentecostais, é a discussão de políticas como pena de morte, prisão
} 
Dessa segunda característica se extrai a terceira: o desprendimento do mundo, que consiste no desprezo pelo universo mundano, pelas vaidades, Vanitas Mundi, "Vaidade das vaidades! Tudo é vaidade!" (eclesiastes, 1: 2). O desprezo se levanta contra tudo aquilo que é obra do homem e que desvia o próprio homem do espírito santo de Deus. Ou seja, são os pecados capitais e seus desdobramentos: A gula seus vícios; A luxúria e seus prazeres; mas também o orgulho e suas vaidades. Nessa última característica os crentes assentam seu desprezo pelos saberes humanos, não só científicos, mas também teológicos, e aqui reside um ponto interessante: o saber não é fator constitutivo do indivíduo pentecostal. Os saberes só são úteis se instrumentalizados, se forem meios para causas finais e nunca a causa final em si, pois saber como causa final é soberba. Como consequência da sua religião construída mais sobre a emoção do que sobre a teologia, os pentecostais foram extremamente menosprezados pela igreja católica e pelas protestantes históricas, o que os levou a sempre nutrir um forte sentimento anticatólico e uma aversão institucional. Esse desprezo pelo mundo, associado à guerra espiritual e à magia constituinte de sentido da vida encerra a tríade sobre a qual o pentecostalismo se sustenta: ênfase na salvação por meio da conversão. Presença imanente e incorruptível do Espírito, sustento do crente e sua arma contra o diabo, desprezo do mundo e suas vaidades como elementos desviantes do caminho de Deus, e instrumentos do diabo, portanto.

Essas três características principais ficam evidentes na liturgia pentecostal. Como desprezam a formação teológica e eclesiástica, o culto não apresenta nenhuma forma canônica. A forma é determinada pela tradição e pela conveniência, e não existiam critérios institucionais para a ascensão ao sacerdócio além da exigência natural da alfabetização e da inspiração pelo espírito santo ${ }^{24}$. A liturgia

perpétua e tortura, com os quais os Pentecostais não concordam, pois dizem que "A vida pertence a Deus". Se pertence a Deus, não pertence ao Estado, e este não pode tirá-la. Geralmente o próprio exemplo de Jesus é invocado para se questionar a tortura ou a pena de morte. Os neopentecostais não apresentam tantas resistências a essas ideias.

${ }^{24}$ Tais características foram preservadas pelas igrejas pentecostais clássicas por muito tempo. Só anos depois, com o desenvolvimento e crescimento das igrejas, e com a chegada das novas ondas pentecostais, surgiu a necessidade de se reestruturar o arcabouço eclesiástico, estabelecendo prérequisitos "intelectuais" para a posição de Pastor, como preparação teológica em instituição de ensino, e a criação de uma classe episcopal (como em alguns ministérios da Assembleia de Deus). Tais características já evidenciam mudanças que vão muito contra o espírito pentecostal clássico, haja vista que se estabelece oficialmente uma hierarquia dentro da Igreja, pois "Pastor" deixa de ser uma vocação e passa a ser uma carreira, ao passo em que aumenta a distância entre o crente e o clero. Tais mudanças poderiam ser fruto do mero crescimento das igrejas, que necessitariam de uma 
se constrói sobre louvores, testemunhos e manifestações intensas do espírito, que tomava conta dos corpos, proporcionando a glossolalia - a marca registrada do pentecostalismo clássico. De certa maneira, a comunidade pentecostal, estabelecida no meio dos marginalizados e amalgamada pela potência dos afetos, fornecia ao rebanho uma possibilidade de ser que era inédita aos seus membros. Essas possibilidades eram as de ser pastor, ser salmista, ser músico, ser ouvido por meio dos testemunhos e de participar de uma igreja com um Deus para chamar de seu, dado que a Igreja católica e as protestantes tradicionais ainda apresentavam uma estrutura clero x fiel muito engessada.

As igrejas pentecostais clássicas prescrevem aos seus membros uma disciplina rígida sobre as condutas da vida, da vestimenta e das relações sociais, que fazem com que o membro da igreja continue vinculado a ela ainda que esteja fora do espaço-igreja. É notório reparar na conhecida figura do crente, de terno e gravata, se homem; vestido comprido e de gestos recatados se mulher. Sempre com a bíblia embaixo do braço, por vezes pregando na praça e com amplo uso da glossolalia, atestando a atualidade do espírito. As pregações de praça por muito tempo foram o principal meio de comunicação pública dos pentecostais clássicos, uma vez que os outros meios de comunicação possíveis (jornais, rádio e televisão posteriormente), além de caros, eram vistos como objetos do mundo, e não de Deus. O chamado à conversão deveria ser ouvido da boca do pregador na praça pública, imbuído do mesmo Espírito que fez Paulo pregar aos atenienses do alto do Areópago.

Os pentecostais clássicos foram a maior forma de expressão do evangelismo brasileiro até 1946, quando a International Church of the Foursquare Gospel, de matriz americana, enviou ao Brasil uma missão comandada por dois ex-atores de cinema estadunidenses - Raymond Boatright e Harold Williams - que ficou conhecida como a Cruzada Nacional de Evangelização e culminou com a fundação da Igreja do Evangelho Quadrangular (IEQ), na cidade de São Paulo em 1953.

A Cruzada Nacional de Evangelização e o surgimento da Igreja do Evangelho Quadricular inauguram a "segunda onda" pentecostal, chamada por

nova estrutura para organizar o rebanho, mas também poderia ser influência do fator neopentecostal nas igrejas clássicas. Para isso, todavia, seria necessário um estudo que não é o objetivo do meu trabalho. Fica somente a reflexão. 
Mariano de deuteropentecostalismo ${ }^{25}$. Essa onda se desenvolve num momento delicado da maior fé do país, a católica, que atravessa um momento de renovação ${ }^{26}$. Os traços que classificam a segunda onda não constituem um corte ou mudança drástica com a primeira. Espiritualmente corresponde mais a um revival da teologia e das práticas clássicas com inovação, todavia, nos métodos de evangelização e no cenário histórico. A única grande mudança identificada na doutrina prática foi a ênfase na atualidade do Espírito como curador dos males, enfatizando seu aspecto terapêutico mais do que a glossolalia, que os clássicos ainda praticavam intensamente (daí a sua classificação como pentecostalismo de cura divina).

Compreende-se que essa onda se desenvolveu no bojo de uma campanha de evangelização, promovida por uma igreja estrangeira que não possuía células no Brasil. Como estratégia de proselitismo, desenvolvida, dessa vez, em ambiente urbano da maior cidade do país, foi necessária a utilização de recursos artísticos e de comunicação em massa até então ignorados ou desprezados pelos clássicos: rádio, panfletos, jornais, cultos ao ar livre (que os clássicos só realizavam nos seus templos) e uma inovação na música e na participação do público na liturgia, que passa a observar os horários da jornada de trabalho das classes suburbanas e proletárias de São Paulo, e a aventura de cultos itinerantes. Se não havia templos, alugavam-se salões, ginásios, teatros, cinemas. Em 1958, o Evangelho Quadrangular lotou o Pacaembu.

Tais práticas e resultados evidenciam duas coisas principais: primeira; o culto e a liturgia evangélicas foram gradativamente deixando seu aspecto de cerimônia e ganhando um novo aspecto de evento: um happening, um show, com músicas amplamente conhecidas e uma abordagem mais "lúdica", um misto de fé e entretenimento. Isso somado ao uso dos veículos de comunicação de massa fizeram

\footnotetext{
${ }^{25}$ Vários outros nomes já foram usados para identificar a segunda onda pentecostal, sendo "cura divina" um dos mais usados. Optei por utilizar a denominação de Mariano para me manter fiel ao marco teórico selecionado e também porque a ideia de uma cura divina já estava presente no pentecostalismo clássico. É certo que os clássicos privilegiavam a glossolalia à cura como manifestação típica do Espírito, porém a cura divina também era praticada. Também a denominação me pareceu a mais feliz em razão do prefixo deutero para indicar ressurgimento, em oposição a neo, que traduz a ideia de novo, porém inovado, não-igual ao anterior. $O$ acerto nessa nomenclatura ficará evidente quando se verificar as diferenças entre o deuteropentecostalismo e o neopentecostalismo.

${ }^{26}$ Sobre a Igreja Católica e as demais religiões no Brasil nos anos 1950, confira-se Giumbelli, 2011. Também Freston, 1993, apresenta um cenário, menos detalhado, da crise do catolicismo brasileiro que contribuiu para a permeabilidade do protestantismo no país.
} 
com que um grande público afluísse aos cultos, eliminando o aspecto sectário e o puritanismo nos costumes que ainda classificavam a primeira onda. Para maior controle do rebanho (ou por maior displicência dele), os rígidos hábitos de conduta pentecostal foram sendo paulatinamente relaxados pelos crentes. Tal público, entretanto, era uma "clientela" menos fiel no que tange à frequência, pois como era maior, era mais difícil de ser controlado. Por isso, os méritos da segunda onda podem ser colocados na sua eficiência evangelizadora: entre 1956 e 1961, o crescimento entre os evangélicos pentecostais foi de $50 \%$ a $70 \%$; enquanto que entre os tradicionais o crescimento foi de $10 \%$ a $20 \%$ (Giumbelli, 2011). Tal crescimento fez com que divisões ocorressem dentro do movimento e várias igrejas emergissem. Foi a época do boom denominacional no evangelismo brasileiro: Brasil para Cristo (1955) Deus é Amor (1962) e Casa da Benção (1964) são exemplos, todas mais ou menos rígidas, mas sempre invocando a cura pelo Espírito e se autopromovendo pelo amplo uso dos meios de comunicação e pelo exibicionismo marcante dos cultos. A Igreja de Nova Vida (1960), fundada no Rio de Janeiro, marcou o início da transição da segunda para a terceira onda.

\section{3}

\section{O neopentecostalismo: surgimento da Igreja Universal.}

A morfologia da palavra neopentecostalismo diz muito sobre a essência da terceira onda pentecostal. Essa onda foi resultado da série de experiências pentecostais que a antecederam, mescladas com mudanças sentidas pelo universo religioso mencionadas no início do texto, principalmente com a ideia de Prosperity Religions cunhada por Gauthier. O caminho trilhado até aqui, desde o início quando se falou de Berger, Gauthier, e das ondas pentecostais começará a tomar a forma do neopentecostalismo.

O prefixo neo, conforme explicado em nota acima, não representa "novo" num sentido de reprodução ou repetição, mas sim com o sentido de "inovado", um verdadeiro "novo". O neopentecostalismo, portanto, é resultado das inovações sofridas pela experiência pentecostal, no curso da segunda metade do século XX. Porém essas inovações não são iguais para todas as igrejas neopentecostais, e que 
tomar o neopentecostalismo como um bloco de valores dogmáticos ou espirituais é intelectualmente arriscado ou temerário.

Mais uma vez, vou me ater às transformações que ocorreram dentro do próprio evangelismo brasileiro para identificar as causas e fatores que marcaram a experiência neopentecostal. É claro que outros fatores, externos ao religioso, como fatores políticos, e a própria atuação da Igreja Católica e dos seus braços sociais para com as camadas mais pobres, também influenciaram na nova forma, mas explicá-los todos aqui tornaria o texto prolixo e fugiria do tema. Para uma abordagem histórica extrarreligiosa, remeto o leitor à obra de Proença (2011).

A segunda onda pentecostal, conforme visto, inovou mais no método evangelizador do que na "dogmática" pentecostal, com uma ou outra mudança que variava de igreja para igreja. As consequências foram um crescimento considerável no rebanho evangélico e a possibilidade de novas experiências evangelizadoras para esse público, que deixava de ter o estigma de marginalizado do pentecostalismo clássico. A marca do surgimento da terceira onda, concordam Freston, Mariano e Hortal, é a fundação da Igreja Universal do Reino de Deus em 1977, por Edir Macedo Bezerra e Ronaldo Romildo Soares no Rio de Janeiro ${ }^{27}$. Apesar da variedade de denominações, Mariano (1999) define como três as características basilares do neopentecostalismo: A guerra santa, o relaxamento dos costumes pentecostais e a teologia da prosperidade ${ }^{28}$.

De certa forma, portanto, quando se explora a história da IURD se descobre a própria história do neopentecostalismo brasileiro, e o que essa novidade acumulou ou rejeitou das experiências evangélicas anteriores. O fenômeno da IURD eclode

\footnotetext{
${ }^{27}$ Freston (1993) afirma que, para além dos critérios dogmático quanto a crença e prática, e metodológico quanto a evangelização, um terceiro critério - o espacial - pode ser utilizado para classificar as ondas. Nesse raciocínio, a primeira seria nortista/paraense; a segunda, paulista; e a terceira, carioca. Tal argumento não se sustenta, pois conforme mostrado, a primeira onda acompanhou também a fundação da CCB em São Paulo, ao passo que a Nova Vida e a Casa da Bênção, componentes da segunda onda, são de origem carioca e mineira, por exemplo. Da mesma maneira, igrejas tipicamente neopentecostais como a Renascer em Cristo e a Mundial do Poder de Deus tiveram berço em São Paulo. Nada disso compromete o restante do raciocínio de Freston, mas o critério espacial parece ser supérfluo para classificar as ondas.

${ }^{28}$ Apesar de muitas igrejas neopentecostais apresentarem características em comum como a teologia da prosperidade, os valores e práticas podem variar substancialmente. Por exemplo, algumas recusam o batismo com água e apresentam uma soteriologia predestinatória nos modelos calvinistas. Outras ressuscitam a glossolalia ou desprezam a guerra espiritual, etc.
} 
num momento de mudança no perfil religioso do brasileiro. A Igreja Católica não apresenta a mesma força e tamanho de fiéis que detinha 30 anos atrás, o crescimento das igrejas protestantes tradicionais era tímido, enquanto os pentecostais ainda aproveitavam a vocação missionária dos anos anteriores para pescar mais almas. Além disso, os novos pastores começaram a desenhar um novo perfil de fiel baseado nas experiências anteriores e na mudança comportamental dos brasileiros. A religiosidade brasileira, que sempre foi mais popular e material do que institucional e formal, repleta de misticismo sincrético, de maneira que o neopentecostalismo também aposta na magia, mas sobre uma nova prática, em especial na IURD. Também o horizonte do desejo mudou: o crente, antes minoritário e marginalizado por seus hábitos e costumes, representava agora uma parcela maior nas estatísticas sobre religião. Isso fez com que os velhos símbolos do pentecostalismo fossem paulatinamente abandonados. As vestes simples, sóbrias, e tudo aquilo que fazia com que o fiel continuasse sendo a igreja fora do espaço-igreja (descrito quando tratei do pentecostalismo clássico) são substituídas por roupas normais, não mais eivadas de valor religioso, mas sim de outros valores: ostentadores, consumeristas, símbolos de pertencimento a um grupo que almeja a ascensão social e maior participação nos ciclos da vida. As condutas social, moral e sexual são relaxadas e uma nova ética surge: a ética da vitória ${ }^{29}$. O público que se avoluma diante do altar neopentecostal não deseja somente aumentar a renda e tornar a vida mais confortável. Busca mais: tornar-se senhor de si próprio, um sujeito independente e senhor do próprio destino. Não se tratava de aumentar a renda do salário, mas de ter a sua própria renda, fruto do próprio negócio. O conforto da vida foi substituído pelo desejo de luxo, consumo de bens duráveis e não duráveis que estabeleciam o sujeito como ascendente na simbologia social. Em suma, não se trata de ascensão social e financeira. Esse novo sujeito busca um novo Eu. Foi a percepção dessa mudança que fez com que os pastores pentecostais iniciassem um novo tipo de ministério. Tal foi o cálculo de Macedo.

\footnotetext{
29 "Em praticamente todos os cultos, o fiel é motivado a 'lutar, a jamais se entregar', pois faz parte de um 'povo eleito' que tem um 'pacto com Deus', 'como os antigos hebreus'. Além disso, os fiéis são sempre retratados pelos bispos e pastores como 'vencedores', guerreiros, lutadores, que enfrentam problemas e humilhações, mas que têm como destino a prosperidade e o direito a uma vida melhor, pois esse é o desejo de Deus" (Guiterrez, 2017, p. 231). Conferir também, nesse sentido, Mariano, 1999, pp. 154 e seguintes. Ressalvo que o nome "ética da vitória" não é utilizado por esses autores. Eu o cunhei apenas para facilitar minha explicação neste trabalho. Não pretendo abrir um novo conceito ou estabelecer nomenclaturas, apenas facilitar o fluxo da argumentação.
} 
Edir Macedo Bezerra nasceu em Rio das Flores, RJ, e sua vida de fé foi a odisseia de muitos evangélicos: família católica na infância, envolvimento com a umbanda na juventude e crente na maturidade. Ele e Soares se conheceram quando frequentavam os cultos da Igreja de Nova Vida, onde ambos foram ordenados pastores e, segundo Mariano (1999), fizeram "estágio" até a fundação da própria igreja. Em 1979, o próprio R. R. Soares deixaria a IURD para fundar a sua própria igreja, a Internacional da Graça de Deus (IIGD), que seria a primeira de outras que brotariam da Universal. Ainda nos tempos do estágio, os dois tomaram contato com a nova espiritualidade americana que ficaria conhecida como teologia da prosperidade e a nova semiótica que essa inovação estabelecia no plano da Salvação.

Conforme exposto acima, não existe um denominador prático-dogmático comum a todas as igrejas neopentecostais. Vou explicar as inovações do neopentecostalismo a partir da experiência da Igreja Universal, marco teórico do trabalho e pedra angular do neopentecostalismo brasileiro. Para outras igrejas, confira-se Mariano (1999).

A Igreja Universal trabalha com duas frentes, que explicam o seu sucesso invejável: a sua fonte material de fiéis, ou seja, a clientela, o público; e a sua fonte institucional e intelectual, ou seja, a igreja, considerada na sua estrutura, e o universo simbólico herdado das duas ondas pentecostais. O objetivo dos próximos itens será de explicar o público da Universal como um público que apresenta uma forte receptividade consumerista e individualista, e que possui perspectivas de mudança da vida própria por meio da emancipação financeira e pessoal no mundo pós-fordista, pela via empresarial. A Igreja Universal acompanhou essas mudanças de público, e se demonstrará como a IURD, por meio da sua prática e estrutura, reflete as ambições do seu público e reorganiza as perspectivas de salvação sob a égide do consumerismo. Em suma, na linguagem de Gauthier, como a IURD se enquadra no conceito de prosperity religion e promove uma educação de valores de produção (e produção de valores) no seu público. 


\section{4}

\section{O Credo Macedo-lurdiano.}

As inovações da IURD no campo religioso brasileiro não são só práticas, mas também dogmáticas. Nessa passagem, gostaria de explorar quatro conceitos que considero essenciais para compreender o universo simbólico da Igreja: guerra santa, teologia da prosperidade, fé Inteligente e ética da vitória. Alguns são derivados das ondas pentecostais, outros são inéditos. Todos interligados, de certa forma, sendo os dois primeiros já mencionados e estudados por sociólogos da religião, enquanto os dois últimos são categorias que eu extraí dos primeiros para explicar melhor meu argumento

Antes, contudo, gostaria de apresentar um resumo da conceituação simbólica que a Igreja Universal proclama aos fiéis e que vai envolver diretamente o seu conceito e projeto de salvação.

"In principio erat Verbum". Deus criou o mundo, e todas as coisas boas que ele contém. Não existem coisas ruins no projeto divino. A criação foi completa e perfeita com a criação do homem, inserido em meio ao Éden para gozar de todas as benevolências, as quais Deus prometeu em abundância. Abundância esta de graças espirituais e fartura material. Quando, porém, entra em cena o diabo, a desgraça começa a acometer o homem, que cai em desgraça e perde a amizade de Deus por pura artimanha do Demônio. O Mal, portanto, está no Diabo e seu projeto destrutivo. Deus, por outro lado, tem um projeto construtivo para a humanidade, e a todo momento convida o homem a restaurar, por meio da obediência, a antiga sociedade que mantinha com Deus. Esse é um elemento crucial na dogmática iurdiana: Deus, símbolo da abundância, quer ver o homem como seu sócio para que o homem prospere e viva nessa abundância prometida. (Mariano, 999, p. 156)

Tal projeto é extremamente desagradável ao Diabo, para quem o Homem está condenado a uma vida de miséria e carestia, para cujo fim o Diabo empregará todo o seu engenho. A Sociedade entre Deus e o Homem deve ser evitada a qualquer custo. Deus, por outro lado, é fiel às suas promessas, ("Deus é Fiel!"), e se prometeu ao Homem a abundância, deve cumpri-la. Para que isso seja possível, Deus e o Homem devem reestabelecer a velha sociedade por meio de um novo pacto, uma nova gramática, uma nova ética, que envolve não só as bênçãos divinas espirituais 
e materiais, mas também a derrota do Demônio e seu projeto miserável. Deus é vitória e o Diabo é derrota. Deus quer do Homem um vencedor na Guerra Santa, enquanto o Diabo o derrotismo em essência. A vida na Igreja Universal começa quando o fiel toma conhecimento das promessas de Deus e da figura do Diabo como obstáculo no seu caminho até a abundância prometida. Se o derrotismo, a desistência, o desânimo, a dúvida ou a preguiça se manifestarem, é o Diabo, que deve ser expulso pelos exorcismos, outro marco da Igreja Universal. (Mariano, 1999, p. 113)

Feitas essas observações, volto a explorar os quatro aspectos mencionados no início dessa parte. A obra evangelizadora da Igreja Universal se sustenta sobre quatro pilares que gostaria de destacar: a guerra santa, a ética da Vitória, a fé inteligente e a teologia da prosperidade.

A guerra santa não deve ser confundida com a guerra espiritual do pentecostalismo, apesar de ter raízes nela. A guerra espiritual, conforme explicado, é a visão de mundo na qual as forças de Deus e a do diabo estão em perpétuo confronto no mundo espiritual, de modo que o crente deve optar entre a Salvação por meio da vida de santidade animada pelo Espírito, ou a danação, por meio do mundo, seus vícios e suas vaidades. A guerra santa, cujo nome, aliás, foi dado pela própria IURD à sua lógica combativa, herda a estrutura maniqueísta da guerra espiritual, mas realoca os cenários e papéis, conforme extraído da mitologia iurdiana. Trata-se dos projetos conflitantes entre Deus e o diabo acerca da vitória ou derrota humana.

Percebe-se aí primeira diferença: Deus e o diabo continuam sendo os conflitantes, mas não são os únicos elementos da equação. $O$ homem também participa ativamente dela, junto a Deus ou o diabo, pois é na guerra que se inscreve a gramática que determinará a sua vitória ou derrota com base nas suas atitudes. A primeira diferença é essa: A guerra santa é uma guerra primeiro do Homem, antes de ser de Deus.

Melhor explicando, na guerra espiritual do pentecostalismo, o indivíduo escolhe um lado, mas o resultado da luta não depende dele. Deus é onipotente, e portanto, vencerá a luta. Ao fiel cabe apenas se proteger na invocação do Espírito ou render-se ao mundo, seus vícios e vaidades. Na guerra santa, contudo, o fiel 
desempenha papel direto na luta, e suas ações influenciam no resultado da Guerra ao final, mas também o presente - leia-se, a sua vida neste mundo - é resultado das suas escolhas e da atitude que toma.

Disso decorre a segunda diferença: a guerra santa não está limitada ao campo espiritual. Antes, seu verdadeiro campo de batalha é o material: o material também é campo de batalha. As bênçãos divinas ou as maldições demoníacas têm causas e consequências espirituais e materiais. Deus prometeu abrir as portas dos céus na outra vida e nesta, e como os efeitos das bênçãos são imediatos, pois a guerra também é imediata, a vitória e a derrota são prontamente identificadas e mensuradas nos valores materiais.

Desse modo, o indivíduo, a todo momento, interage com mediadores entre os dois mundos, de ambos os lados, cujas interações têm resultado imediato sobre sua vida, seja em matéria de graça, saúde, bem-estar, paz interior e continência dos vícios, mas também estabilidade conjugal, empregatícia, financeira, familiar, social. O diabo, que é quase tão forte quanto Deus, também tem seus mediadores espalhados por toda a parte, almejando a desgraça e perdição dos homens. São eles o jogo, o crime, o vício, a homossexualidade e as instituições diabólicas: a maçonaria, a Igreja Católica, que espalha a idolatria e a "fé emocional", mas principalmente as religiões de matriz africana, inimigo número 1 da IURD, vista como a religião do próprio Diabo na terra, antro de magia e feitiçaria (Sánchez, $2014)^{30}$. Nem os vírus e bactérias escapam da taxação de interventores infernais. Contra eles, todo crente deve se levantar e combater, pois é uma luta que se trava pelo bem de si próprio e dos irmãos. (Mariano, 1999, p. 114)

A arma que o fiel tem para combater o diabo é a fé. Mas por fé na Igreja Universal se entende um conceito bastante heterodoxo se comparado às outras denominações cristãs. A fé media uma outra espécie de relação com o divino, que começa pelo empoderamento humano para somente depois se relacionar com o divino. Não basta abandonar o diabo, é preciso determinar a obra divina na vida

\footnotetext{
${ }^{30}$ Apesar do Antiecumenismo ser uma marca da IURD e dos pentecostais como um todo, a igreja recentemente procurou a construção de uma imagem de concórdia com os outros credos, com o convite a candomblecistas e a padres católicos para que visitassem o Templo de Salomão. Confirase $\quad$ https://www.paulopes.com.br/2018/05/universal-recebe-candoblecistas-no-templo-desalomao.html\#.XEDzETBKjcs e https://www.gospelprime.com.br/pastores-padres-culto-templode-salomao/
} 
própria, determinar que Deus atue em seu favor e derrame as bênçãos que Ele prometeu.

Para que isso seja possível, o fiel deve compreender primeiro que a salvação (ou danação), conforme extraído dos parágrafos acima, está inscrita na relação da guerra santa e depende da participação do indivíduo nela. Conhecendo essa verdade, o homem deve decidir qual atitude tomará na batalha.

O fiel que toma conhecimento das promessas de Deus deve, a partir de então, determinar que sua vida será abençoada por essas promessas. O Homem dá o primeiro passo em direção a Deus quando determina que será um vencedor - ou seja: uma pessoa que vai superar a si mesma e aos outros para mudar de vida e viver na abundância material e espiritual prometida.

O verbo determinar não é de pouco uso e significado na simbologia iurdiana. Determinar-se um vencedor, determinar-se um combatente na guerra santa contra o Diabo e a miséria existencial envolve uma nova construção do indivíduo projetada sobre si próprio que começa por um reconhecimento: "Eu sou herdeiro das promessas divinas, e determinarei que elas ocorrerão na minha vida!" Quando o fiel reconhece e determina isso, ele começa a tomar as rédeas da mudança que quer operar. Toma conhecimento de seu sócio - Deus - e da obediência que deve a ele para o estabelecimento da Sociedade. Mas uma vez reestabelecida a sociedade, o fiel passa a se identificar por um estranho título: credor de Deus.

Se Deus é fiel; se Deus é senhor de todos os bens e prometeu a abundância aos que estabelecem sociedade com ele; se eu estabeleci a sociedade com ele e fiz minha parte no acordo, então está na hora d'Ele cumprir a sua parte no acordo. Até o seu adimplemento, eu tenho um crédito contra Deus.

O substantivo Deus e a sua combinação com o adjetivo devedor, tão estranha ao Cristianismo, é perfeitamente aplicável no credo iurdiano. Isso porque a relação do Indivíduo com Deus não é a de submissão, mas antes de sociedade. É linear, e não oblíqua: 

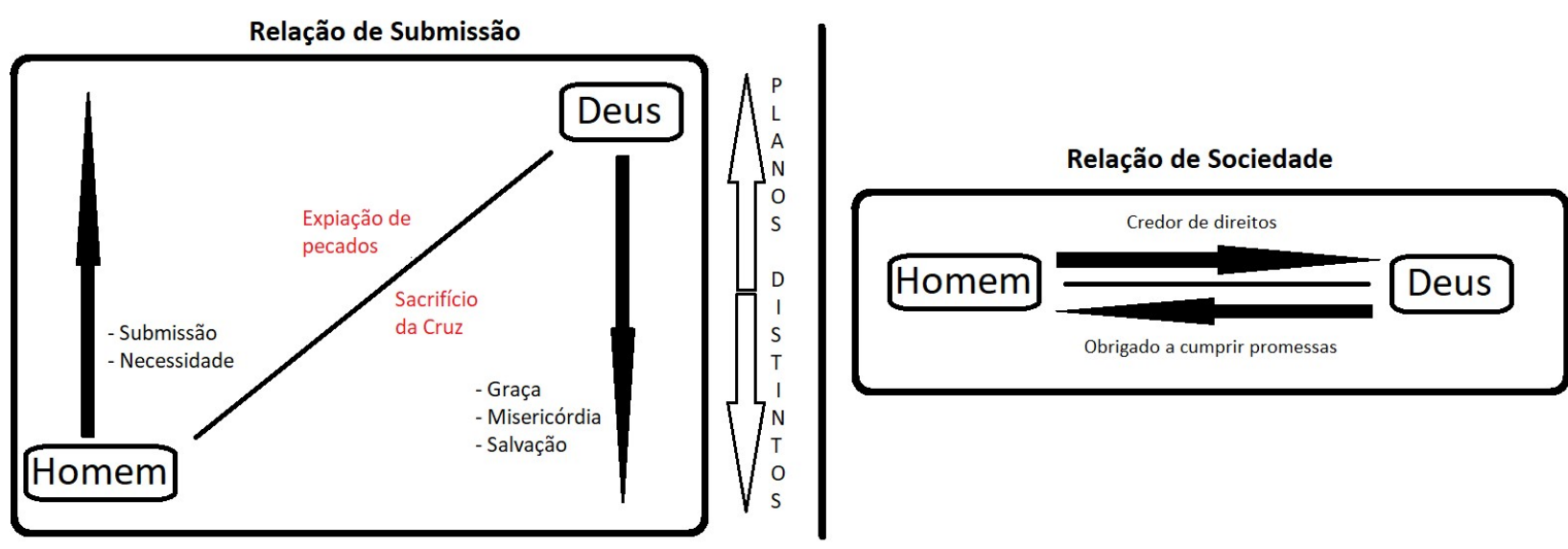

As relações oblíquas são aquelas nas quais o criador e a criatura, por comporem polos existenciais necessariamente distintos, não podem jamais ocupar o mesmo plano metafísico, pois o criador é essencialmente superior à criatura e não possui nenhuma forma de compromisso necessário com ela. No cristianismo clássico (e até mesmo no pentecostalismo), a transação entre os dois planos só existe nas esferas categóricas de pecado e graça, e consequentemente danação e salvação, que são sintetizadas pelo sacrifício de Cristo na cruz.

A IURD inaugura uma nova perspectiva, a linear. As velhas categorias de pecado, cruz, sacrifício, misericórdia, graça incondicional são mitigadas ou deslocadas para planos secundários. O leito da salvação tem aspecto imediato e material, concretizado pelo acordo assinado bilateralmente, entre partes iguais com obrigações mútuas, sendo que só uma das partes pode se esquivar do acordo ou se recusar a assiná-lo. E esta não é Deus - é o Homem.

Assim que o homem toma consciência da sua situação de credor de Deus, ele deve passar a se comportar como tal e determinar sua posse e direito sobre toda a abundância que Deus prometeu. É necessário ter o que Macedo chama de "fé possuidora", ou seja, aquela que toma posse das promessas, pois este é o primeiro passo do caminho para obtê-las (Mariano, 2003).

Sintetizando isso, o próprio Bispo Macedo afirmou, em um culto de 31 de dezembro de 2011:

\footnotetext{
${ }^{31}$ Esse gráfico e esquema são de minha autoria.
} 
“É a parceria. Sim ou não? A parceria, a aliança. Com Deus é a mesma coisa! Quando a gente é fiel a ele (então) nós passamos a ter direitos! Direitos, privilégios que os outros não têm! A partir dos dízimos nós podemos cobrar... Esse é o verbo certo! Cobrar de Deus o que ele prometeu: abrir as janelas dos céus!"32

É por isso que o fiel, desde o início, deve assumir uma postura de vitória no combate e abandonar qualquer pensamento de derrota ou miséria. Assume-se, para tal o comportamento de vitorioso, a ética da vitória. A miséria é o projeto do Diabo, que tenta atrapalhar o cumprimento das promessas de Deus. Mas como Deus é fiel, se cumprirmos nossa parte no acordo, a vitória é garantida. Espírito derrotista é sinal do Demônio agindo, e deve ser imediatamente exorcizado.

Nesse sentido, ainda o bispo, em 20 de abril de 2018, após promover dois exorcismos:

"é a voz que o Diabo também fala para você lá fora! É ou não é? 'Você não vai ser ninguém!'; 'Você nasceu pobre e vai morrer pobre!' É ou não é? Esses espíritos jogam a semente da dúvida. Se você crê, se você acredita, se você aceita então vai acontecer! Mas se você desafia e diz 'Faz isso agora!' aí ele arreda!" ${ }^{33}$

Desse modo, a ética da vitória compreende conhecer as promessas de Deus, determinar que elas serão suas e, a partir de então, comportar-se como um vencedor. Esse comportamento é a marca da fé iurdiana, mas que é diferente do que comunmente se costuma chamar de fé nas outras vertentes cristãs. É por meio dessa fé, que tem nítido caráter de ação, que a vida do fiel muda.

Consciente das promessas e da fidelidade de Deus, da guerra santa, da necessidade de tomar uma atitude positiva e para determinar a posse sobre as bênçãos, o próximo passo é aprender o uso da fé. A IURD ensina que a Fé do indivíduo não deve ser de caráter contemplativo; antes deve ser inscrita em outro patamar, ativo. Se Deus prometeu a abundância, o fiel tem que agir para tomar posse das bênçãos que Deus destinou para a sua vida. A essa fé ativa, não contemplativa, visionária das promessas de Deus, o próprio Bispo Macedo chama de "fé inteligente", que é o abecedário da linguagem de parceria entre Deus e

\footnotetext{
${ }^{32}$ Disponível em https://www.youtube.com/watch?v=1wqI2cr6V04; trecho entre 0:07 e 0:39

${ }^{33}$ Disponível em https://www.youtube.com/watch?v=FnjFRkxAI4o\&t=1649s; trecho entre $26: 55 \mathrm{e}$ 27:33
} 
Homem para a concretização das promessas. A fé contemplativa é inútil, portanto. Infrutífera: não serve para nada. "A fé sem inteligência é fanatismo!" disse Macedo em um santo culto em São Paulo ${ }^{34}$.

A fé inteligente figura então como pedra chave para a salvação, é o acesso à abundância prometida por Deus aos seus filhos-sócios. Deus quer pessoas capazes, ousadas, com visão e inteligência para vencer o Diabo e estabelecer a boa sociedade. Mas como se usa a fé inteligente? Em primeiro lugar, abandonando a fé antiga, típica das igrejas históricas, de contemplação, petição, invocação, penitência. Essas não servem, segundo a teologia iurdiana, porque Deus não gosta de fazer favor. A fé inteligente começa quando o fiel cobra de Deus, exigindo, com firmeza pignoratícia, a abundância prometida.

De novo faço exemplo do Bispo Macedo, no trecho de pregação no Templo de Salomão selecionado abaixo, quando ele conta uma história dos seus tempos ainda no início da Universal:

\begin{abstract}
"Uma noite, foi numa quinta feira, eu cheguei em casa e a Ester [Ester Bezerra, esposa do Bispo] falou 'Edir, eu preciso de dinheiro hoje porque amanhã eu tenho que fazer compra pro final de semana' E não tinha nada 'A geladeira tá vazia, acho que só tem água e ovo.' Eu disse 'Que isso, Esther?! Mas eu já te dei todo o dinheiro que eu tinha! Tudo que eu tenho é o dinheiro da passagem!' Então ela falou 'É, mas não tem mais nada não. Já acabou! E eu tenho que fazer compra!' Sabe o que aconteceu? Ao invés de eu me ajoelhar e falar 'Ah, Senhor... tem misericórdia de mim! Olha, tem compaixão! Veja a minha situação!' Hum hum! [O bispo faz um gesto negativo com o dedo] eu peguei a bíblia, peguei a Ester nas mão e disse 'Vamos orar!' Nos ajoelhamos. Ela ficou de um lado da cama e eu fiquei do outro. Demos as mãos e eu cheguei e disse [O bispo emprega um tom de fala agressivo] 'Senhor! Presta atenção! Tu disseste "Se duas ou três pessoas concordarem na terra, será concordado no céu!". Nós dois aqui concordamos: olha, chegou o momento que nós estamos nessa situação. Estou envergonhado, humilhado diante dessa situação. Como que eu não tenho dinheiro pra comprar comida?! [O bispo grita] O Senhor promete abrir as janelas dos Céus para aqueles que são fiéis a Ti, então eu QUERO ver isso!' Mas eu não falei com palavras bonitas não. Eu falei com RAIVA! Eu falei irado! Eu falei REVOLTADO com aquela situação. [O bispo volta a falar num tom manso] Por quê? Porque eu estava humilhado... E eu pedi resposta: 'Se o Senhor é verdadeiro... Se essa Palavra [agarrando a Bíblia e voltando ao tom agressivo] é verdadeira... Se isso que aqui tenho crido é verdadeiro... Se o Deus que está aqui registrado é verdadeiro, então eu quero uma resposta AMANHÃ porque amanhã eu tenho que trazer dinheiro pra casa pra comprar comida.
\end{abstract}

E a Ester, que tinha vindo de uma igreja tradicional, ela ficou apavorada... Ela abriu os olhos desse tamanho... Porque ela ficou com medo da minha oração! 'Ih, vai cair Fogo do Céu aqui agora!' Caiu fogo sim! Mas de Revolta, por aquilo que eu tinha DE DIREITO e que eu não estava tendo. Entendeu o que eu estou falando? Quando você tem uma fé alicerçada na Palavra de Deus, você não aceita derrota! Você não aceita ficar pra baixo! Você não aceita ficar pra trás! Porque você crê no Deus que prometeu "Eu sou contigo!" . Entendeu o que eu estou falando? Isso é Fé o quê? [A congregação responde: Inteligente!]

\footnotetext{
${ }^{34}$ Disponível em https://www.youtube.com/watch?v=WxaKze9jarM
} 
Inteligente! Racional! Porque você COBRA de Deus o que ele prometeu! Essa é a Fé que você tem! E que muda essa situação. Você vai ver que você vai arrebentar!"135

Esse trecho é o próprio Macedo explicando um resumo de tudo que procurei descrever até aqui: promessa divina de abundância, atitude positiva e ativa, ética vitoriosa, fé inteligente, com abandono da fé oblíqua pelos méritos de Cristo que caracteriza as outras igrejas. Chocante também é a linguagem e o tom que o Bispo usa, como se fosse um credor exigindo algo de um devedor inadimplente.

Todos esses fatores se completam na teologia da prosperidade, marco do neopentecostalismo e da IURD. A teologia da prosperidade é resultado de todos esses fatores, e constitui a gramática da salvação. Se no pentecostalismo clássico o tempo estava próximo e o arrebatamento era iminente, a teologia da prosperidade neopentecostal propõe um novo ideal de salvação, não vindouro, mas imediato, com a substituição do caráter escatológico pelo consumerista. Também aqui o pentecostalismo e o neopentecostalismo se divorciam.

\begin{abstract}
A teologia da prosperidade subverte radicalmente o velho ascetismo pentecostal. Promete prosperidade material, poder terreno, redenção da pobreza nessa vida. Ademais, segundo ela, a pobreza significa falta de fé, algo que desqualifica qualquer postulante à salvação. Seus defensores dizem que Jesus veio ao mundo pregar o Evangelho aos pobres justamente para que eles deixassem de ser pobres. Da mesma forma, Ele veio pregar aos doentes porque desejava curá-los. Deus não é sádico, tem um grande prazer no bem-estar físico e na prosperidade material de seus servos. O contrário não tem respaldo nem sentido bíblico. Os reais servos de Deus não são nem nunca serão párias sociais. Durante muito tempo, o Diabo obscureceu a visão dos crentes a despeito dessas verdades, mas agora, consciente da ardileza satânica, eles começam a tomar posse das promessas divinas. (Mariano, 1999, p. 159)
\end{abstract}

Verifica-se então o estabelecimento de um novo conceito de salvação e de uma nova gramática soteriológica. Mas como funciona essa gramática? Deus quer estabelecer a sociedade com aquele que ousa proclamar seu direito sobre as bênçãos, determina sua vitória e está disposto a agir. Mas Deus precisa de provas dessa boa intenção e determinação. Já que a fé inteligente se opera por meio da ação, é preciso que o Homem aja para depois Deus agir - até porque o Homem é credor de Deus. Deus é aquele que contrai a dívida a posteriori. Deus, em resumo,

\footnotetext{
${ }^{35}$ Disponível em https://www.youtube.com/watch?v=BA6Ry4efOgk. Não consegui identificar a data da ocasião, mas o vídeo foi carregado em 28 de outubro de 2017
} 
precisa ser provocado ao cumprimento de sua parte no acordo. Qual é o método da provocação? O dízimo.

Nas igrejas tradicionais que mantêm o costume do dízimo, este é visto como uma relação entre o fiel e sua igreja, na qual o fiel destina parte da sua renda periódica à igreja para que esta, enquanto instituição, possa manter o seu funcionamento ou obras sociais. O tratamento que o dízimo recebe na IURD também é diferente. Não é uma relação entre fiel e igreja, mas sim entre homem e Deus. Substancialmente o dízimo não deixa de ser uma parcela da riqueza do fiel, mas seu significado simbólico é revisto. Não é um ato de caridade ou ajuda financeira que o fiel presta à igreja de coração; na Universal, o dízimo são as arras, o sinal, a caução fidejussória que garante o vínculo societário entre Deus e homem e catalisa as obrigações do contrato estabelecido. O dízimo enquanto provocação é a forma encontrada pelo credor humano para provocar 'amigavelmente' seu devedor divino como se fosse um jogo de apostas. "Prove-me! Prove-me que o Senhor é Deus de abundância! Vou lançar aqui uma oferta de $R \$ X$, quero ver o Senhor me devolver e em dobro/triplo, etc" A tradicional oração enquanto canal de comunicação entre o Homem e Deus é substituída na IURD pelo dízimo. Não quer dizer que a IURD não valorize a oração e o contato íntimo com o divino, mas o principal meio de se encontrar a bênção é entrando no jogo do dízimo: a moeda de câmbio da Salvação.

Fiel que não paga o dízimo é fiel medroso, fiel que não tem confiança, fiel que duvida. Fiel que tem o diabo na sua mente, que o impede de tomar as bênçãos preparadas para sua vida. Não age. O que tem de medo lhe falta em inteligência. É desprovido da fé inteligente e da ética da vitória.

A lógica da teologia da prosperidade, representada no dízimo como forma de realização de bênçãos por meio do agir e da fé inteligente, apresenta um fator inédito na história do protestantismo: a salvação deixa de ser uma condição ou estado do fiel e passa a ser um jogo no qual se ganha ou perde conforme a jogada seja bem empregada. Se o fiel cumprir com a receita prescrita, o sucesso é garantido, pois Deus não falha. Se o fiel estiver com algum problema cuja origem é diabólica, deve frequentar uma sessão do descarrego para se purificar. Para casos mais graves, o exorcismo no altar. A questão é: os mapas para a bênção ou o relapso 
estão postos. Se o fiel eventualmente perder uma jogada ele sempre está apto a recomeçar (Torres, 2007) e vencer na próxima. Essa oportunidade de eliminação da derrota permanente pela possibilidade de recomeço dentro do frame estabelecido pela Teologia da Prosperidade é um dos grandes diferenciais de captação de fiéis pela IURD e pelas outras neopentecostais que sigam o mesmo modelo.

A teologia da prosperidade evidencia então a última grande diferenciação entre o pentecostalismo e o neopentecostalismo. Enquanto que, para aquele, o desprendimento do mundo é essencial e condição para ser salvo, para este o mundo é extensão do projeto salvador de Deus, e inafastável para a salvação.

\section{5}

\section{Ser e não ser: o público da Universal.}

Uma vantagem que a Igreja Universal tem sobre as demais denominações religiosas é o fato dela conhecer muito bem o seu rebanho. O perfil de fiéis será o grupo já mencionado em dois momentos deste trabalho. As pessoas que anseiam por mudança. Como a IURD foi fundada no subúrbio carioca, era natural que a primeira leva de fiéis fosse composta pelas classes baixa e média. No entanto, o que se verifica hoje -e a igreja faz questão de observar - é um rebanho que quer mudar de vida. Não se trata de enriquecer somente. Trata-se de ser e de não ser. De não ser mais assalariado, de não ser mais empregado, de não ser mais locatário, de não ser mais devedor. Deve-se passar a ser: empreendedor, dono de imóvel próprio, negócio próprio, associar os prazeres e luxos da vida à própria existência - o que não envolve esvaziar a vida de sentido por meio do excesso. O fiel da Universal é aquele que vê a sua vida como peça fundamental num campo de batalha entre a vitória e a derrota. Seu público é combatente, portanto, e a Igreja é o arsenal de armas para a batalha.

Ao mesmo tempo em que a Igreja Universal cresceu, seu público amadureceu. Não era mais a multidão proletária ou de pequenos comerciantes reunida no coreto da Praça do Méier. Seu ideal de público hoje se reúne aos milhares no Templo de Salomão, espécie de Vaticano Macediano construído no bairro paulistano do Brás e inaugurado em 2014 com a presença da presidente da República e com capacidade para dez mil fiéis. O ingresso no Templo só é permitido se observadas as regras de conduta, entre as quais, o vestuário, 
disponíveis numa página independente do site do templo ${ }^{36}$. Essa mudança no tratamento dado à roupa já revela algo sobre como a igreja conhece seus fiéis: as roupas são símbolo de consumo, riqueza, decência, por vezes polidez, e de expressão individualizada do $E u$. A liberalização dos costumes flui conforme o espírito da Igreja Universal como uma das propriedades da benção divina, e portanto da Salvação ${ }^{37}$.

Edir Macedo soube então aproveitar-se de duas mudanças no perfil da sociedade brasileira: o declínio do catolicismo e da velha simbologia institucional religiosa, e as mudanças nas formas de vida, trabalho e do horizonte de desejo do brasileiro, principalmente o evangélico.

Quem observou o reflexo que o público iurdiano influenciou no perfil eclesiástico da IURD foi Ferrari, para quem:

\begin{abstract}
O bispo Macedo estruturou sua Igreja com perfil evangelístico híbrido, aberto à cultura popular e aos conflitos das massas nas grandes metrópoles. Percebeu que havia enormes contingentes desesperançados e que as religiões tradicionais não estavam lhes transmitindo sentido à vida. Estabeleceu uma mensagem e uma ritualística que encontraram sintonia com o senso comum do público frustrado com as ofertas religiosas costumeiras. Fez sincretismo entre várias correntes religiosas presentes no imaginário popular e apresentou, de modo agradável, uma mensagem flexível com os comportamentos.
\end{abstract}

$[\ldots]$

Em termos religiosos, não criou nada de novo, mas soube sintonizar e sintetizar com harmonia o vasto imaginário das diferentes crenças populares das culturas locais e as angústias das crises sociais. Para tudo estabeleceu diretrizes pragmáticas, satisfazendo os

36 Encontradas em https://sites.universal.org/templodesalomao/regras-de-conduta-no-templo-desalomao/:

"Não é permitida a entrada de pessoas usando minissaias ou outras roupas indiscretas e indecorosas. Bermudas, chinelos, camisetas sem manga, bonés, camisetas político-partidárias, de times ou clubes esportivos também não são permitidas."

${ }^{37}$ Uma das "ferramentas" que a IURD mais aprecia utilizar para dialogar com a massa de fiéis são os seus antigos críticos e/ou adversários que hoje são membros fiéis da igreja. Se forem pessoas conhecidas do grande público, melhor ainda. No mesmo culto já mencionado de 20 de abril de 2018 (https://www.youtube.com/watch?v=FnjFRkxAI4o\&t=1649s), o bispo Macedo dá um exemplo disso quando convida o ex-sambista Gibi, integrante da segunda geração do conjunto "Originais do Samba" e hoje convertido à Universal. Gibi era conhecido do público iurdiano pela sua gravação de "Reunião de bacana", de Bezerra da Silva (conhecida pelo seu refrão "se gritar pega ladrão não fica um, meu irmão!"), dedicada a Edir Macedo e à IURD. Convertido, foi chamado ao altar do Templo de Salomão, vestindo paletó e camisa de punho duplo:

Macedo diz: "Quer dizer, seu cara de pau, você fez uma canção para mim... 'se gritar pega ladrão não fica um, meu irmão' [o bispo gargalha]. O Gibi fez isso pra mim, pessoal! Pra Igreja Universal! E hoje você tá aqui, vagabundo?" [Gibi ri e responde "Na fé, bispo!"], Macedo ri novamente, satisfeito.

Em seguida, Gibi dá o seu depoimento, dizendo sobre "como serviu ao diabo e aos encostos por 34 anos" e hoje está liberto. 
anseios do público e colhendo vultosos resultados financeiros pela estreita vinculação do culto com o dinheiro, inspirado na Teologia da Prosperidade americana (Ferrari, 2007)

Observando as mudanças no próprio público, a IURD revê constantemente as suas programações. O núcleo duro dos cultos e da liturgia não mudam, centralizando-se no santo culto dominical. As outras celebrações e eventos da igreja são distribuídos pela semana, em horários que visam a jornada de trabalho, de modo que o horário e a temática de cada evento estejam em direta sintonia com as particularidades e interesses dos fiéis. Tal calendário é observado em todos os templos da IURD, desde que tenham estrutura e público suficiente para tal:

\begin{tabular}{|c|c|}
\hline Dia da Semana & Programação \\
\hline Domingo & $\begin{array}{l}\text { Reunião para os que desejam ter uma experiência } \\
\text { real com o Altíssimo. } 6 \mathrm{~h} ; 9: 30 \mathrm{~h} \text { - Transformação de } \\
\text { Pais e Filhos. } 18 \mathrm{~h} \\
\end{array}$ \\
\hline Segunda-Feira & $\begin{array}{l}\text { Nação dos 318: Palestra motivacional para o } \\
\text { Sucesso Financeiro. } 7 \mathrm{~h} ; 10 \mathrm{~h} ; 12 \mathrm{~h} ; 15 \mathrm{~h} ; 18: 30 \mathrm{~h} \text { e } 22 \mathrm{~h}\end{array}$ \\
\hline Terça-Feira & $\begin{array}{l}\text { Dia da Cura: Oração para a restauração da saúde } \\
\text { física e emocional. } 10 \mathrm{~h} ; 15 \mathrm{~h} \text { e } 20 \mathrm{~h}\end{array}$ \\
\hline Quarta-Feira & $\begin{array}{l}\text { Escola da Fé: Reunuião para o fortalecimento } \\
\text { espiritual. } 10 \mathrm{~h} ; 15 \mathrm{~h} \text { e } 20 \mathrm{~h}\end{array}$ \\
\hline Quinta-Feira & Terapia do Amor. $10 \mathrm{~h} ; 15 \mathrm{~h}$ e $20 \mathrm{~h}$ \\
\hline Sexta-Feira & $\begin{array}{l}\text { Mudança de sorte: oração forte para a remoção do } \\
\text { estresse, depressão e carga negativa. } 10 \mathrm{~h} ; 15 \mathrm{~h} \text { e } 20 \mathrm{~h}\end{array}$ \\
\hline Sábado & $\begin{array}{l}\text { Jejum das causas impossíveis: o impossível para o } \\
\text { homem é possível para Deus. } 7 \mathrm{~h} \text { e } 10 \mathrm{~h}\end{array}$ \\
\hline
\end{tabular}

O amadurecimento do público da Igreja Universal também veio acompanhado de seu sucesso nas aventuras financeiras, e algumas tentativas de mudança realmente deram certo. Seu público enriqueceu, e o ambiente de riqueza e consumo como sinônimos de bênção que a Igreja proporciona é evidente pelas simbologia, que começa pelas abotoaduras de prata na camisa do bispo. A Igreja explora constantemente os testemunhos de fiéis que se identificam ou como empresários ou como frequentadores dos cursos de educação financeira que a Igreja oferece. A todo momento o pastor ou bispo pergunta: (i) "Qual era o valor das dívidas?" ou (ii) "Quantos clientes você tem agora na sua carteira?" ou (iii) "Qual o valor da casa onde vocês moram hoje?" ou (iv) "E agora, qual é a situação 
patrimonial?". Respostas comuns são (i) "15 milhões de débito, hoje sanados"; (ii) "Duas empreiteiras multinacionais", (iii) "10 milhões" ou (iv) "Uma cobertura em Alphaville e dois carros importados". É a materialização das bênçãos de "um povo focado, que almeja uma virada financeira" que Deus prometeu, que encarna numa ética consumerista. Esta é a Nação Universal ${ }^{38}$.

As perguntas e respostas mencionadas no parágrafo anterior foram retiradas de uma propaganda da Nação dos 318, dos projetos que a Universal mantém, de enorme destaque. Tal projeto (sempre disponível às segundas-feiras, conforme o calendário) é voltado para a situação financeira e busca enfatizar nos fiéis a disciplina e o ânimo. Trarei mais detalhes sobre a Nação no próximo ponto.

\section{6}

\section{'Aedificabo ecclesiam meam': A Estrutura da Igreja Universal}

"A IURD possui a estrutura de uma empresa", diz Mariano (1999), e o autor vai além, dizendo que é muito difícil separar a igreja das empresas de telecomunicação vinculadas a Edir Macedo. Todo o império midiático que a igreja tem à sua disposição é usado em seu favor: horas de canal televisivo, rádio, jornal ("Folha Universal"), shows e uso da imagem de artistas. Inovando sempre: o jornal da igreja, por exemplo, traz matérias sobre passagens bíblicas, elementos de fé e mensagens da igreja, mas também notícias do cotidiano. Esses meios também são usados para a publicidade do relicário de itens sacros que a igreja comercializa.

A própria Igreja se organiza obedecendo a um modelo empresarial, e sobre a organização da IURD vai mais uma diferença entre ela e os seus antecessores pentecostais: uma instituição rigidamente hierarquizada, disciplinada e de política episcopal. Apresentando progressão de carreira, todas as funções e promoções são estabelecidas pelo critério da eficiência, pautado pelo volume de fiéis e recursos arrebanhados.

Seu caráter empresarial e de hierarquia rigidamente estabelecida e fechada é observado por Mariano, em outro trabalho:

\footnotetext{
38 A fonte das perguntas e respostas está disponível em https://www.youtube.com/watch?v=2twvkzHcTn0
} 


\begin{abstract}
Nada democrático, o governo eclesiástico verticalizado da Universal é fundamental para a consecução de seu sucesso religioso, político e empresarial. Além de reforçar a unidade e a coesão denominacional, a concentração do poder eclesiástico dinamiza o processo decisório e agiliza enormemente a transmissão das ordens superiores e a realização dos trabalhos administrativos, organizacionais e evangelísticos. Da mesma forma, ela permite à liderança centralizar integralmente a administração dos recursos coletados; centralização financeira que é crucial para bancar investimentos altos e estratégicos, como a compra e expansão de redes de rádio e tevê, a aquisição e construção de imóveis de grande porte, a abertura de congregações e de novas frentes de evangelização, a criação e manutenção de gravadoras, editoras e empresas diversas que orbitam em torno de suas atividades religiosas. (Mariano, 2003a, p. 57)
\end{abstract}

Odêmio Antônio Ferrari (2007) também não hesita em classificar a estrutura eclesiástica da IURD como empresarial, numa observação um pouco mais incisiva que a de Mariano.

O bispo Macedo, inspirado no perfil empresarial moderno e vendo as limitações das instituições religiosas estabelecidas, organizou uma estrutura eclesial racionalizada. Formulou uma mensagem sincrética dinâmica, que promete resultados eficientes diante das carências populares. (Ferrari, 2007, p. 177)

Como Ferrari tem formação teológica, compara o clero iurdiano com o perfil clerical das denominações protestantes clássicas e indica que estas organizam seu clero com base no critério "profissão missão", segundo o qual o ministério religioso é atribuído conforme o carisma (no sentido bíblico de inspiração, presença de Espírito, vocação), enquanto que na IURD (assim como na Igreja Católica), a atribuição de posição dentro da hierarquia obedece ao critério "profisssão função", ou seja, a regra de progresso não é a de vocação para o sacerdócio, mas sim de uma meritocracia na condução dos negócios da Igreja, principalmente na expansão do rebanho.

O clero da IURD é extremamente institucionalizado, no qual os obreiros integram a camada mais baixa. São voluntários, e por isso não lhes é exigida nenhuma educação teológica específica; os pré-requisitos são apenas o dom de línguas, além a obediência e disciplina. (Mariano, 2003a, p. 56) Sua função é de ajudar em todas as tarefas ordinárias da igreja: organizar os fiéis, recolher envelopes, providenciar microfones, etc. Fazem os serviços auxiliares mais básicos junto ao público e também cuidam da segurança e vigilância dos templos. Não chegam a ser propriamente clérigos da IURD, mas não estão no mesmo nível simbólico que os fiéis. Existem obreiros e obreiras. 
Depois dos obreiros, só a ordenação masculina é permitida. Os pastores são uma classe dividida em duas subclasses: os pastores nomeados e os pastores consagrados, sendo estes titulares de templos e habilitados para a administração de quaisquer sacramentos da Igreja, enquanto aqueles são auxiliares dos principais, têm por função a assistência ao pastor titular no altar, sentando ao lado deste. Podem auxiliar em exorcismos e em outras atividades "sacramentais", desde que sob supervisão e com autonomia bastante reduzida. São um veículo de comunicação entre a congregação e o clero. (Mariano, 1999, p. 61; Idem, 2003a, p. 56) ${ }^{39}$

Os pastores são os clérigos por excelência, e à semelhança dos bispos devem ser casados (no caso dos consagrados) e podem ter filhos. A Igreja, contudo, desencoraja veementemente novos filhos após a ordenação, sugerindo inclusive a vasectomia (Mariano, 1999, p. 61; p. 62). Não há uma formação institucional para os pastores: todo aprendizado que devem dominar para exercer suas funções é aprendida na prática, com base no talento. Os pastores representam um corte institucional intransponível com os fiéis, e são funcionários efetivos da Igreja, não podendo se dedicar a outras atividades, ao contrário dos diáconos e obreiros, tendo, inclusive, responsabilidades administrativas em relação ao templo onde exercem seu ministério. A relação dos clérigos com os fiéis deve ser puramente institucional. A IURD apresenta uma fisionomia episcopal bem definida, proibindo que o ministério seja escolhido pelos membros da congregação (o que a separa ainda mais da forma presbiteriana de algumas igrejas pentecostais), e possuiu uma política de rotatividade constante, de maneira que nenhum pastor ou bispo fique vinculado a uma unidade ou templo por muito tempo, e quando um novo pastor ou bispo chega, é muito incomum que sua história seja contada aos fiéis, como forma de evitar vínculos pessoais e afetivos entre pastor e rebanho ${ }^{40}$. (Mariano, 2003a, p. 57; Ferrari, 2007, p. 175)

\footnotetext{
39 "Os pastores praticamente não têm folga. Estão sempre atarefados com quatro, cinco cultos diários, aconselhamento pastoral, programas de rádio, vigílias e, no final do expediente, com montanhas de cédulas de dinheiro para contar. Dormem pouco. Trabalham muito, além da conta até." (Mariano, 1999, p. 61)

${ }^{40}$ Quanto à remuneração dos pastores, escreve Mariano:

"A remuneração dos pastores da igreja é segredo de Estado. Sabe-se, porém, que os salários variam, de acordo inclusive com o número de filhos do pastor [e isso talvez explique em parte o estímulo à vasectomia]. Os nomeados, a maioria, ganham apenas uma ajuda de custo e, quando provêm de outros Estados, chegam a morar, mal acomodados, nas minúsculas e insalubres dependências dos templos. Já os 4.500 pastores consagrados, os quase 100 bispos e as dezenas de líderes regionais e
} 
Os bispos são minuciosamente escolhidos entre aqueles que literalmente fizeram carreira dentro da IURD: obreiros, depois pastores auxiliares, depois pastores titulares. São enviados à sede da Igreja em São Paulo para serem treinados, onde aprendem oratória, boas maneiras (inclusive etiqueta com o vestuário) e modos de interagir com o público. Chega a ser curioso notar que existe um estereótipo de "modo de falar" dos pastores e bispos: todos eles parecem mais ou menos o Bispo Macedo falando. Os bispos têm funções litúrgicas, mas também tomam parte na administração da igreja, dividindo entre si as catedrais, em notório paralelismo com o episcopado católico romano. Todo o processo de seleção e promoção, de pastor nomeado a consagrado, e de consagrado a bispo, obedece ao critério da arrecadação de recursos para a igreja. (Mariano, 2003a, p. 57). Esses recursos são obtidos pelas ofertas, pelo dízimo, e por doações espontâneas, e seu destino dentro da estrutura eclesiástica é desconhecido. $\mathrm{O}$ volume de arrecadação tende a ser proporcional ao número de frequentadores do templo onde a arrecadação é feita, de modo que fica evidente a equação "mais fiéis = mais arrecadação". A utilização de tal parâmetro como critério de promoção clerical evidencia com ainda mais veemência o aspecto empresarial da estrutura da IURD.

Acima dos bispos, há os conselhos: "Conselho Mundial de Bispos"; "Conselho de Bispos do Brasil" e "Conselho dos Pastores", que escolhem nomeações, aprovam diretrizes e aplicam sanções e disciplinas ao clero iurdiano. Acima dos Conselhos está Edir Macedo.

A alta cúpula do clero é responsável pela distribuição do capital da Igreja nos programas que ela sustenta: os litúrgicos, como os cultos santos de domingo, as santas ceias e as sessões do descarrego, mas também em outros programas voltados para a recuperação, estruturação e disciplina dos fiéis, como por exemplo a Terapia do $\mathrm{Amor}^{41}$, que promove conselhos de bem estar conjugal e vida amorosa

estaduais [OBS: dados da época do trabalho, 1999] têm suas despesas cotidianas custeadas pela igreja, à qual prestam contas. Os bispos, segundo Carlos Rodrigues, recebiam entre 4 e 5 mil reais em 1995. Os pastores que dirigem templos grandes em bairros nobres, com membresia e clientela maiores, tendem a receber salários maiores" (Mariano, 1999, p. 62). Grifos meus.

\footnotetext{
${ }^{41}$ Em vários momentos da pesquisa, seja assistindo aos cultos, seja lendo os veículos de notícia oficiais da igreja, me deparei a atenção que a igreja dava à questão dos relacionamentos amorosos e familiares dos fiéis por meio da terapia do amor, do livro "casamento blindado", de Renato Cardoso e Cristiane Cardoso (filha do bispo Edir Macedo) ou da coluna que o casal mantinha na "Folha Universal". Acredito que uma pesquisa dedicada a esse cuidado amoroso de si que o fiel procura desenvolver diz muito sobre a capacidade normativa da igreja e seu potencial de construir uma
} 
em geral, e o programa A Última Pedra, de recuperação de dependentes químicos. Meu foco maior, naturalmente, se concentrará nos programas da Nação dos $318^{42}$.

Da Nação dos $318^{43}$, o programa que mais faz sucesso é o de educação financeira, chamada palestra motivacional para o sucesso financeiro, cujas reuniões são as mais procuradas, atrás apenas do culto de domingo. (Gutierrez, 2017). Esse programa não é um culto, antes se assemelha a um curso do estilo coaching e é aberto a membros que não são necessariamente fiéis da Igreja Universal. Consiste numa palestra motivacional e de educação financeira básica e avançada. As palestras ocorrem sempre às segundas feiras, em todos os templos da Universal que tenham capacidade de abrigar uma reunião dessas.

As reuniões tomam a forma de palestras eivadas de algum elemento litúrgico, como os hinários, popularmente chamados de corinhos na IURD. A "Nação" tem seu próprio corinho, constituído por canções de vários ritmos diferentes: pagode, axé, brega, com direito até a uma versão iurdiana do hit "Poeira" de Ivete Sangalo (rebatizado de "É Guerra!"), mas sempre apresentando um viés popular. Alguns nomes do repertório já são autoinformativos sobre seus temas: $E u$ tenho a Vitória!; Vai, Miséria! Vai!; Quero ser o primeiro!; Sou Vencedor!. As letras também são interessantes no sentido em que reforçam os valores da guerra santa, da ética da vitória e da teologia da prosperidade. Em Faço parte da Nação, a atualidade da salvação, seu viés consumerista e o quesito empresarial como objetivo de vida são evidentes:

Eu vou, eu vou prosperar

Eu vou arrebentar

Tudo que eu quero eu vou conquistar

\footnotetext{
subjetividade afetiva no seu rebanho. Tal programa pode dizer muita coisa sobre a construção subjetiva iurdiana que procuro desenvolver nestas páginas. Infelizmente, com o tempo escasso e sob o risco de fazer um trabalho com um marco pouco fechado, não consegui me dedicar suficiente a esse cuidado afetivo iurdiano de modo a utilizá-lo substancialmente no meu trabalho, mas acredito que outro pesquisador que queira se aventurar nessas searas pode desenvolver trabalhos muito interessantes.

${ }^{42}$ A igreja preservava ainda dois orfanatos, dois asilos e curso de alfabetização para adultos entre outras obras. (Mariano, 1999, p. 60).

${ }^{43}$ Nome alusivo ao episódio bíblico contado em Gênesis, 14, no qual Abraão reuniu uma força de 318 homens para libertar seu sobrinho Ló das masmorras de Sodoma.
} 
O nome de Jesus eu vou glorificar

Tudo que ligarmos aqui

Lá no céu ligado será

Deus eu ligo aqui agora

Minha casa, minha empresa,

A fartura em minha mesa,

Meu carro importado,

Casamento abençoado,

Só pra Te glorificar.

\section{Reproduzo abaixo o conteúdo de uma das palestras do curso, ministrada pelo bispo Edson Costa, na Catedral de Fortaleza ${ }^{44}$.}

O bispo já começa enfatizando: 'Deus não te deu limite!', e utiliza as descrições do Profeta Isaias para descrever a Grandeza de Deus ${ }^{45}$ para dizer que isto não é suficiente. Pede, então, um quadro branco e pilots. "Eu vou te descrever quem é Deus! E se hoje você tiver a visão, meu caro... Você vai arrebentar em Nome de Jesus! Amém?" Aqui o bispo muda completamente o tom, abandonando o de pregador e tomando um de coach, com uma certa dose de humorismo.

"Este Deus! Este Deus quer fazer você não apenas um milionário: este Deus que quer fazer que o seu dízimo seja milhões! É diferente uma coisa da outra! Este Deus que quer fazer de você uma pessoa grande! Uma pessoa mega! E você pode chegar lá porque você é Filho de Deus! Amém?"

Em seguida, vai para diante do quadro. Começa a "aula": "Visão. A primeira coisa que um milionário tem que ter. Todo milionário antes de ser já se enxergava milionário. Antes de ter o primeiro milhão ele já acreditava que podia chegar lá. Toda pessoa que hoje tem sua empresa, antes de ser empresário já se enxergava empresário. Foi só questão de tempo: a visão já estava dentro dele".

O bispo vai ao quadro, com o objetivo de mostrar aos fiéis quão grande Deus é. Ele brinca com a própria letra diversas vezes, mantendo um tom jovial. "Não devia ter matado tantas aulas de caligrafia!" [a plateia ri]

No final, para resumir, o bispo faz uma série de desenhos e rabiscos que queriam representar o plano cósmico, invocando um discurso científico: o bispo fala do universo "que segundo os cientistas, tem a forma de um cilindro com o meio achatado em razão da compressão espaço-tempo" e que teve sua origem no Big Bang. De lá o palestrante vai decrescendo: tira galáxias, separando a Via Láctea, constelações, sistemas, sistema solar, planeta terra, países até chegar na vida. "3 Milhões de espécies de vida. Uma delas somos nós, o Homem. [...] Não é pra ver o quanto você é pequeno. É pra perceber o quanto diminuímos Deus!",

\footnotetext{
${ }^{44}$ Disponível em https://www.youtube.com/watch?v=5dTCtbF37Lo

${ }^{45}$ Isaias, 40:12: "Quem mediu as águas na concha da mão, ou com o palmo definiu os limites dos céus? Quem jamais calculou o peso da terra, ou pesou os montes na balança e as colinas nos seus pratos?"
} 
prosseguindo: "Existem 7 bilhões e 200 milhões de pessoas na terra. Uma delas é quem? [plateia: Eu!] Isso mesmo, você! Então quem é você? Você é um indivíduo dentre outros 7,2 bilhões de habitantes que compõem uma espécie dentre outras três milhões de espécies que habitam um planetinha, que gira em torno de uma estrelinha, dentre outras 100 bilhões de estrelinhas, que compõem UMA galáxia dentre outras 200 bilhões de galáxias!"

Dito isso, o bispo invoca Salmos, $8: 1^{46}$, e passa a discursar, num tom vibrante, sobre quem é o homem nesse universo enorme "para que Deus se lembre dele, e quem é o filho do Homem, para que Deus o visite? E agora, meu caro, enche o peito para dizer comigo bem alto: 'Fizeste-o, no entanto, um pouco menor do que Deus!' [a plateia repete em uníssono com o bispo] Eu to mostrando pra você um Deus que conta as estrelas pelo nome [...] Tudo é pequeno diante de Deus! E mesmo tudo sendo pequeno ele diz assim ó 'O ser humano é a minha obra prima! Ele é o máximo da minha criação! Eu criei tudo isso aqui e eu DEI PRO HOMEM DOMINAR!' Amém?

Então quem é você? Você é um pouco maior do que isso! [o bispo mostra as ordens de grandeza desenhadas no quadro] E eu pergunto pra você, meu amigo: você veio aqui pra pedir um emprego? [com um tom irônico na voz] Você veio pedir pra Deus aumentar seu salário? Você veio pedir pra Deus apenas aumentar dez por cento das suas vendas? Dos seus clientes? Você veio pedir pra Deus te tirar do sufoco? É ESSE DEUS que você veio buscar aqui?"

\section{7}

\section{Síntese conclusiva}

O trecho separado representa bastante o que quis representar até aqui, em resumo: A Igreja Universal é um fenômeno particular, representante do que se pode chamar de neopentecostalismo. Este foi resultado de experiências pertencentes ao processo de evolução histórica do Pentecostalismo, em contato com as transformações que as religiões sofreram no curso das mudanças do Capitalismo e das classes sociais ao longo do século XX e início do século XXI, de modo que o Neopentecostalismo, seu crescimento e aventura de sucesso são mostras de que o mundo não está mais "secular". A secularização antes parece indicar uma crise das religiões egrégias do que o declínio do religioso em si.

A IURD soube se afirmar e crescer no contexto de Prosperity Religion egresso das transformações do horizonte religioso, e isso foi possível porque ela conseguiu entender as modificações do próprio público religioso - que compreende perceber a modificação mediana dos projetos de vida e da consequente necessidade de nova representação religiosa para eles - e sintetizá-los num formidável esquema dogmático e institucional, dotado de uma capacidade de diálogo invejável, e que

\footnotetext{
46 "Senhor, Senhor nosso, como é majestoso o teu nome em toda a terra! Tu, cuja glória é cantada nos céus."
} 
espelha os desejos e afetos dessas novas populações carentes de uma nova ética religiosa e metafísica. Ela mesma apresenta uma forma empresarial e um programa de carreira para seu clero.

Os elementos que a IURD utiliza na sua liturgia e teologia cotidianas realocam as experiências e valores mágicos das ondas pentecostais que a precederam para compor uma nova gramática do divino e da Salvação, totalmente de acordo com as ambições consumeristas dos seus fiéis, mas exigente de um processo disciplinador e educador, estipulando a vida (e a vida eterna) como objetivos a serem adquiridos por meio de um saber específico. Um "como fazer". Por isso, além de reinventar a simbologia cristã, a Igreja se presta a um verdadeiro serviço de educação empresarial aos fiéis.

$\mathrm{Na}$ "aula-culto" do bispo, todos esses elementos se evidenciaram: incrível capacidade de conhecer seu público e dialogar com ele, tanto em valores simbólicos, como o "ficar rico" como em didáticos (modelo "aula", uso do quadro, utilização do discurso científico, tom coloquial, descontração, piadinhas, etc.). A ideia de que Deus quer fazer dos homens milionários (e com dízimos milionários, reafirmando o veículo de Salvação), para por fim mandar a mensagem final: não se quer apenas ficar rico: se quer mudar de vida! Se quer deixar de ser empregado/assalariado/comerciante para virar empregador/participante nos lucros/empreendedor independente.

A própria relação com Deus ganha outra forma, deixa de ser obliqua e vira plana, contratual. O divino é pactuável, e a salvação depende quase que exclusivamente do Homem, em total subversão aos valores do Cristianismo tradicional, mas confluindo com as mudanças religiosas heterodoxas, fruto dos novos tempos que Gauthier usou como título do seu livro: The Neoliberal Age.

Resta saber o que de Neoliberal se esconde por trás do véu do Templo. 


\title{
O Buraco da Agulha: Definindo Neoliberalismo
}

\author{
"There has been many a ferocious quarrel \\ among sectarians who worship the same god" - \\ Walter Lippmann, The Good Society \\ "Some kind of deliberate planning is necessary. \\ But which kind and how much?" - \\ Aldous Huxley, Ends and Means
}

Na noite de 02 de setembro de 2018, o Museu Nacional da Quinta da Boa Vista, no Rio de Janeiro, foi destruído por um incêndio que consumiu quase a totalidade do seu acervo bicentenário. Nos dias que seguiram a tragédia, marcados por protestos, milhares de imagens foram compartilhadas em redes sociais denunciando um culpado para o incêndio. Nessas imagens, peças icônicas do acervo do museu destruído, tais como o crânio de Luzia ou o acervo funerário de ShaAmun-en-su, apareciam com os seus nomes escritos e, logo abaixo pelos dizeres "Não sobreviveu ao Neoliberalismo".

A mensagem passada pelas imagens era lacônica: não havia muito além de culpar o neoliberalismo pelo incêndio do Museu Nacional. Não se sabe como, nem por quê, mas de alguma forma o neoliberalismo era o culpado ou, no mínimo, responsável pela hecatombe. Ainda assim, de certa maneira a mensagem parecia fazer sentido ou não ser de todo desprovida de verdade.

A invocação do neoliberalismo como causa do incêndio encontra eco em certa acepção do fator neoliberal como fonte de todas as mazelas, como se fosse uma potência determinista e indomável (Fortunes Vulnera), ou o resultado de uma conspiração travada no seio da História pelo capitalismo para ressuscitar o velho liberalismo solapado pelos anos e acabar com tudo o que o Estado social representava. Trataria de uma política dominadora e seletiva daquilo que deve ser interesse e o que não deve, valendo-se do encolhimento do Estado como ferramenta 
primordial. O desinteresse do poder neoliberal pela conservação do Museu Nacional teria evitado as obras emergenciais que o prédio tanto carecia. O neoliberalismo, sem fazer nada, tacou fogo no velho museu, mas antes de incendiálo, fez seu ensaio geral na capela universitária da UFRJ em 2011. Naquele mesmo ano, o neoliberalismo esteve por trás do vazamento de óleo na Bacia de Campos provocado pela Chevron. Em 2015 provocou o rompimento da barragem de Mariana. Em 2019 fez a mesma coisa em Brumadinho.

Essa visão apocalíptica e fatalista do neoliberalismo é ingênua e equivocada, mas não é esquizofrênica. Ela encontra suas raízes em interpretações mais profundas da questão neoliberal como tem sido tratada até aqui pelo pensamento marxista - ou antes, por pensadores que se identificam como marxistas - segundo os quais o neoliberalismo integra as categorias marxianas de interpretação do capital e do processo dialético da História. Aí cabe falar de neoliberalismo como encolhimento do Estado social e liberação das forças do capital incontinente; ou ainda, o neoliberalismo é um processo ontológico e social de subjugação de tudo a favor do mercado; o Neoliberalismo pode figurar ainda sob um caráter ideológico: falseamento da realidade e mascaramento das relações de violência. Outros afirmam o neoliberalismo como o novo espírito do capitalismo.

Todas essas interpretações reconduzem o neoliberalismo ao fator capital e o subordinam a ele e à sua lógica. Com uma divergência ou outra, atribuem ao capital uma posição quase onipotente, capaz de determinar o curso da vida, o controle do tempo e dos desejos e com um poder quase completo sobre o indivíduo. O neoliberalismo seria, nesse entendimento, apenas mais uma das estratégias montadas pelo capital-imperador para prevalecer e perseverar. Nesse horizonte, uma análise pura do Neoliberalismo fica prejudicada por não se conseguir apreender o fenômeno neoliberal como separado do fator capital - ou sequer cogitar essa possibilidade.

A abordagem que desejo fazer do neoliberalismo é diferente. Conforme expliquei na parte teórico-metodológica, procuro estudar o neoliberalismo como uma nova razão de mundo tal como explorada na obra de Dardot e Laval. Para isso, cumpre investigá-lo como norma produtora de subjetividades, produtora de mundo e produtora de sentido. Busca-se o neoliberalismo como norma biopolítica 
organizadora de Sociedade e como veio constitutivo (e disciplinar) do sujeito. Essa abordagem, notoriamente foucaultiana, é utilizada por Dardot e Laval para compreender o papel que essa forma de governabilidade desempenha no capitalismo atual, não como submetido a um poder, mas antes o neoliberalismo como uma relação de poder. Mais do que isso: é uma relação de poder que não é somente coercitiva ou repressiva.

Aqui reside, acredito, um dos maiores méritos dos autores porque conseguem enxergar na obra de Foucault uma análise cirúrgica dos métodos de poder e da genealogia do neoliberalismo, mas sem deixar de vislumbrar a senda de Marx e o legado de seu pensamento para tratar neoliberalismo e capitalismo como devem ser tratados: nem o primeiro é uma obra da arte da política independente do segundo; nem o segundo é produtor consciente e onisciente do primeiro.

Dessa maneira, o neoliberalismo opera como forma de governo e formação das gentes, da produção de mundo e de sentido, submetendo os sujeitos à empresa enquanto forma de (auto) organização, e à concorrência enquanto norma geral da vida. Os sujeitos submetidos não são somente os sujeitos puros, as pessoas. Também os sujeitos produtores de sujeitos são inscritos no quadro delimitado pela empresa e pela concorrência: escolas, a polícia, o Estado, as Igrejas. Todos passam a manejar sua matéria-prima de sujeitos e modelá-los conforme a norma concorrencial-empresarial. Por isso, quando se define neoliberalismo como diminuição do Estado ${ }^{47}$, ampliação do universo do mercado para outras esferas da vida, desmantelamento do aparato social e etc., não se está falando inverdades, mas se está tomando o efeito pela causa.

Parte do meu raciocínio de tratar o neoliberalismo como uma coisa diferente de um simples produto consciente do capitalismo envolve mostrar que o neoliberalismo teve uma gênese distinta do fator capital, e que - à semelhança do que quis demonstrar quanto ao neopentecostalismo - foi também fruto de experiências, suas combinações e seus casamentos com outros fatores. Não foi,

\footnotetext{
${ }^{47}$ Aqui quero fazer relação com a clássica definição de Neoliberalismo como desmonte do Estado, mas, conforme pretendo mostrar mais à frente, o Neoliberalismo enquanto forma governamental tem na intervenção do Estado uma das suas maiores ferramentas. O Estado Neoliberal é essencialmente interventor. Por diminuição do Estado aqui compreendida eu quis fazer eco à ideia de que o Neoliberalismo é destruidor do chamado Estado Social, e nesse sentido, é verdadeira a acusação.
} 
portanto, algo determinado por qualquer demiurgia que seja. A História do neoliberalismo é muito interessante e importante para a compreensão do fenômeno. Por essas razões, considero importante que um breve resumo histórico do fenômeno seja repassado nessas páginas, apenas naquilo que diz respeito ao trabalho. A história do neoliberalismo acaba com a ilusão de que o fenômeno é coeso e consensual - antes é produto de várias divergências metodológicas e interpretativas entre seus "founding fathers". Também afasta a presunção de que o neoliberalismo seja uma discussão econômica, como queria David Harvey. É um pouco mais do que isso, e não tem nada a ver com espíritos malvados que não se importam com museus em chamas.

\section{1}

\section{O Colóquio Walter Lippmann e a Crise do Liberalismo Clássico}

Os dois primeiros equívocos que uma leitura leviana da história do Neoliberalismo pode indicar são de que, primeiro, o Neoliberalismo é o ressurgimento do Liberalismo clássico como forma política e econômica, e segundo, que o marco inicial do Neoliberalismo foi a fundação da Sociedade de Mont-Pèlerin em 1947. Para melhor compreender o Neoliberalismo e sua verdadeira gênese, cumpre retroceder ainda mais, precisamente para o período de 26 a 30 de agosto de 1938, onde, em Paris, se realizou o chamado Colóquio Walter Lippmann, organizado pelo filósofo Louis Rougier, cujo argumento era a comemoração e discussão acerca do livro de Lippmann, An Inquiry into the principles of the Good Society (ou doravante simplesmente, The Good Society/ Lippmann, 1943), publicado no ano anterior, cujo nome bem sugestivo remete ao clássico de Adam Smith e que tinha acabado de ganhar sua primeira edição francesa, rebatizada como La Cité Libre.

O objetivo de Lippmann era encontrar os caminhos que levassem à Grande Sociedade (The Good Society), entendida essa como o estágio histórico e a constituição política e econômica de maior salvaguarda das liberdades humanas. Lippmann, que escreve às vésperas de uma segunda guerra mundial, numa época em que se avolumam os totalitarismos soviético e nazifascista nos Estados Europeus, ameaçando novamente o continente com a perspectiva de guerra, se propõe analisar também a história das perspectivas da Grande Sociedade, e dos 
projetos humanos que buscaram conquistá-la ou destruí-la, Desses projetos, o Liberalismo Clássico havia se afirmado com notória participação no processo de proteção às liberdades por meio da doutrina do Laissez-Faire e dos direitos naturais, que constituíram um arcabouço férreo para enjaular o Estado absolutista e permitir o pleno desenvolvimento da atividade humana.

Se por um tempo o liberalismo clássico foi o remédio adequado de preservação da liberdade e contenção do poder, inscrevendo no Estado a proibição da sua intervenção da natureza das coisas, Lippmann entendia que o velho modelo liberal havia se tornado obsoleto com o progredir da História por um fator específico: o liberalismo clássico não havia conseguido acompanhar o desenvolvimento da vida humana, e isto se deu porque o seu modelo foi assentado sobre mitos construídos pelos pioneer liberals (primeiros liberais), por exemplo, acerca do naturalismo imanente ao mercado, ao direito e ao próprio homem, cujo caráter mítico, quase fantasioso, não havia sido percebido pelos latter-day liberals (liberais tardios) $^{48}$.

De maneira mais incisiva, o laissez-faire enquanto princípio foi exagerado e levado a consequências que tiveram origem na corrupção intelectual do seu papel dentro da ordem liberal. Tal princípio era uma categoria pensante sobre qual deveria ser a melhor forma de funcionamento do mercado, e não o que deve ser (ou pior) o que é o mercado. Pela sua natureza de não-intervenção na ordem das coisas, o laissez-faire simplesmente prescrevia uma política regente de determinados objetos passíveis de figuraram numa ordem de mercado, mas em nenhum caso o laissez-faire determinava esses objetos, ou os conceituava. Que objetos são esses? O contrato, o título, a propriedade, o crédito, a proteção ao comércio. Tais entidades, por não serem naturais, advêm da obra jurídica, e não do próprio mercado, e portanto a ideia de uma "naturalidade do mercado", compreendendo a natureza como um espaço de ausência de intervenção, é falsa

\footnotetext{
${ }^{48}$ Questão de esclarecimento: por latter-day liberals, Lippmann não queria se referir aos seus contemporâneos no Colóquio, mas sim aos advogados do Liberalismo da segunda metade do Século XIX, entre os quais o mais proeminente, segundo Lippmann, era Herbert Spencer. (Lippmann, 1943, p. 182). Sobre esses mesmos sujeitos, afirmava Eucken: "Los liberales del siglo XIX eran en su mayoría partidarios de la politica del 'Laissez-Faire'; los apoyaba una gran tradición, pero algunos de ellos eran epígonos. En resumen, el liberalismo de dicha época es sólo ima rama del gran árbol de la cultura europea que descansa sobre la libertad y que sólo fue amenazado o perdió fuerza cuando la linertad entró en decadencia." (Eucken, 1956, p. 519)
} 
(para não dizer ingênua), e portanto o laissez-faire sozinho não basta. É necessário algo mais para garantir o seu funcionamento. Nos primeiros anos do liberalismo prático, ao fim do século XVIII, isso não era tão evidente. Passado o tempo, porém, a ignorância desse fato teria preparado o caminho do liberalismo para a sua própria queda.

Esse arcabouço "mitológico" do liberalismo clássico havia, no entender de Lippmann, corrompido a capacidade dos liberais tardios de perceberem dois fatores que os solaparam: a revolução industrial, de um lado; a divisão social do trabalho de outro. Ao estacionarem o liberalismo na sua casca mitológica - isso é: ao persistir na ideia de um naturalismo inato, estático, pré-conceitual ao mercado, ao trabalho, ao progresso, os velhos liberais ignoraram o peso da História obrada pela mesma sociedade livre que eles buscavam encarecidamente proteger. Era necessário demolir todo o discurso fundador construído na metafísica para poder então reconstruí-lo na esfera prática da História humana e da instituição político-jurídica. Nos dizeres de Lippmann:

\begin{abstract}
Ao assentar os direitos sob fundações sobre-humanas, toda a justificativa de justiça, adequação e adequação social do direito foi inibida. $\mathrm{O}$ esforço para adaptar o direito à dinâmica econômica foi destinado a uma espaço diminuto e periférico. Foi removido da seara da investigação científica e da argumentação racional. Dessa maneira, o conveniente mito dos primeiros liberais transformou-se num fundamentalismo dogmático pelos liberais tardios e, sob a justificativa de lealdade a princípios inalteráveis, governos e juízos adaptaram o direito às pressões de grupos de interesses. Na sua teoria, o direito já estava completo: mas, na realidade, a necessidade de inovação jurídica lhes foi apresentada por meio da agitação popular, pelo lobby parlamentar, pelos notáveis memorandos dos juristas. Eles enfrentaram uma necessidade de nova improvisação, e conciliaram as novas exigências com o seu direito inalterável por meio do emprego de elaborada causídica jurídica. (Lippmann, 1943, p. 244) ${ }^{49}$
\end{abstract}

O parágrafo destacado resume muito bem o argumento de Lippmann sobre a crise: de um lado, teórico, há o apego ao mito fundador do liberalismo num

\footnotetext{
${ }^{49}$ Tradução minha. No original:

By placing legal rights on a superhuman foundation, the inquiry into the justice, the suitability, and the social convenience of laws was inhibited. The effort to adapt the laws to the dynamic economy was driven underground and out of sight. It was removed from the real of scientific inquiry and rational debate. Thus the convenient myth of the pioneer liberals became the dogmatic fundamentalism of the latter-day liberals, and, in the guise of loyalty to unalterable principles, legislatures and courts shaped the laws to meet the pressures of interested groups. In their theory the law was already completed: but, in fact, the need for new law was brought home to them by popular agitation, by legislative lobbying, by the impressive briefs of the lawyers. They met the new need by improvisations, and reconciled the new laws with the unalterable law by employing an elaborate legal casuistry
} 
naturalismo metafísico do qual era urgente se livrar. De outro lado, político, há o problema da formação de grupos de pressão sobre a sociedade organizada, seja pelas elites que manipulam o jogo político, seja pela participação intransigente das massas na política pela via revolucionária ou de extensão dos direitos políticos pelas reformas eleitorais do século XIX. A doutrina liberal posta ganhou um caráter dogmático "talmúdico" O que Lippmann tanto critica é o fato de se ter esquecido que o liberalismo não tem origens ultra-humanas, mas antes é uma política e que a crença nessa gênese metafísica corrompeu o verdadeiro propósito do liberalismo: a proteção às liberdades pela contenção essencial do poder.

Se o mercado, o direito e os outros fatores que sustentam o liberalismo não são naturais, então é necessária a sua constante observância e proteção. O descuido na condução do liberalismo como forma de governo, ou o esquecimento de que sua preservação depende do conhecimento do seu caráter histórico (e não natural) concluíram, segundo Lippmann, na sublimação do liberalismo e na ascensão do que o autor chamou de "o grande dogma de nossa era" ("The dominant dogma of the age"), a saber: a ideia de que os processos emergentes da divisão do trabalho podem ser coordenados por uma autoridade altaneira, e a impossibilidade de qualquer felicidade humana ou progresso histórico sem a condução e diretivismo das atividades intelectuais, culturais, laborais e econômicas pelo Estado coletivista. Em suma: o "dogma" - e quando Lippmann fala em dogma, ele está querendo comparálo ironicamente à figura do dogma religioso - é o extremo oposto da Grande Sociedade.

A apuração de Lippmann era portanto de que o avanço da intervenção estatal no controle da vida, esse totalitarismo ${ }^{50}$, era fruto de uma crise do liberalismo.

\footnotetext{
${ }^{50}$ Os neoliberais trabalharão com uma terminologia própria quando estabelecem a sua Teoria Geral do Estado, e quanto a isso, cumpre esclarecer brevemente que, no tocante às relações entre Estado e Sociedade, o Estado pode se classificar como Totalitário ou Liberal. Totalitário é aquele Estado que, em alguma escala e de alguma forma, extravasa as suas funções administrativas e faz uso do poder (legítimo ou não) para conduzir a vida social num determinado sentido, quanto aos objetivos, formas, práticas ou valores da sociedade, que ficam assim subordinados à autoridade política estatal. Liberal, por outro lado, é o Estado que respeita a Sociedade e a vida social, e que se atém somente às questões da administração ou da ordem pública. O Estado Totalitário, segundo os teóricos neoliberais (incluindo o próprio Lippmann) não se confunde com o Estado Autoritário, ditatorial, podendo existir democracia (no sentido de participação dos cidadãos no Governo) no Estado Totalitário. O Totalitarismo, todavia, é o primeiro passo para o Autoritarismo, sendo o ponto de partida do Caminho para a Servidão, para usar o título hayekiano. Para uma descrição mais detalhada dessa terminologia, e sua distinção com o Estado Autoritário, conferir Zippelius, 1997. É interessante notar que essa terminologia e essa visão não era algo único dos neoliberais. A
} 
Identificadas as origens da crise na ingenuidade naturalista do mito fundador do liberalismo consubstanciado no laissez-faire como negação de qualquer intervenção e no agigantamento da instituição estatal para a satisfação ou de elites políticas ou de massas demagogizadas cumpria perguntar: é possível salvar o liberalismo? Para alguns, a crise era interna ao liberalismo, e as intervenções estatais planificadoras são resultado e parte dessa crise. Para outros, a intervenção estatal era o problema, e a crise do liberalismo era seu resultado. Se o liberalismo precisa ser salvo, de quem deve ser salvo? Do Estado planificador, coletivista e totalitário? Ou esse mesmo Estado era produto do liberalismo e sua incapacidade de acompanhar o devir histórico e, nesse sentido, o liberalismo deveria ser salvo dele próprio? Tal era a questão do colóquio.

A reunião de Paris durou poucos dias, mas foi suficiente para que os seus participantes debatessem bastante sobre a crise. O colóquio terminaria com a tentativa de fundação do chamado Centro internacional de estudos para a renovação do liberalismo, uma espécie de versão liberal da "Internacional Comunista". A experiência do Centro acabou sendo malograda pela eclosão da guerra no ano seguinte, mas foi o ensaio para Mont-Pèlerin, anos depois.

Até aqui busquei apresentar um histórico bastante descompromissado do Colóquio, bem como qual foi a motivação da sua ocorrência. Quanto à sua história, não quero me alongar mais, e remeto à obra de Audier e Reinhoudt (2018) para mais detalhes. Nas próximas páginas, procurarei traçar o fio condutor do raciocínio do Neoliberalismo a partir das perspectivas de três figuras principais, que tomaram parte do Colóquio: Lippmann, von Mises e Hayek. Desejarei apresentar um modo de se apreender o Neoliberalismo enquanto norma regente da vida e da ação humana a partir das contribuições desses três teóricos e que serão mais interessantes para o casamento que pretendo desenhar com a prática neopentecostal da IURD.

Antes, em respeito à história e às leituras que fiz para esse trabalho, cumpre dizer algo sobre aquilo que tanto Foucault (2008) quanto Dardot e Laval (2016) chamaram de ordoliberalismo, ou neoliberalismo alemão, porque, conforme ressalto, o neoliberalismo e as suas vertentes não são estanques: conversam entre si

problemática de uma planificação da Economia e da Vida encontrava espaço nas discussões de outros autores também, como Aldous Huxley, que no seu Ends and Means, escrito no mesmo ano do Colóquio, dedica um capítulo a essa temática. 
e estabelecem relações de parentesco teórico, em boa parte originadas das respostas que foram ensaiadas à pergunta de Lippmann sobre a vida ou morte do liberalismo. Era evidente que, ao tempo do colóquio, não havia um clubismo teórico dividido entre "Ordoliberais", ou "Alemães" versus "Miseanos" ou "Austroamericanos", apesar de preferências intelectuais do colóquio prepararem terreno para esses grupos, eles só viriam a se formar após o fim da guerra, e só receberiam essas alcunhas depois. Cumpre recordar também que tanto o pensamento alemão quanto o austroamericano não é um bloco opaco, existindo diferenças e divergências menores dentro do mesmo grupo (como entre von Rüstow e Röpke, por exemplo)

\section{2}

\section{O ordoliberalismo, ou neoliberalismo "alemão"}

Uma contemplação da vertente "alemã" do neoliberalismo envolve estudála como duas perspectivas: quadro e processo. Por quadro, se compreende o arcabouço teórico e institucional sobre o qual se dará o processo, ou seja, o quadro é uma construção intelectual sobre o que deve ser o liberalismo (ou neoliberalismo, que seja), a política, a regulação e a intervenção para, a partir daí, operar o quadro sobre o mundo da vida (essa operação é o processo) ${ }^{51}$. Os ordoliberais partiriam de uma perspectiva cética à ideia de ressuscitar o liberalismo. A velha ordem liberal enquanto política social havia sido solapada não por não se adaptar à revolução industrial, mas por ser essencialmente incompatível com os produtos dela, (e nesse sentido, vão de encontro a Lippmann, para quem a revolução industrial era a própria revolução do liberalismo). O liberalismo clássico havia sido gestado no mesmo ambiente que a Fisiocracia, ainda pré-industrial, numa Europa ainda predominantemente rural e cujo contato do homem à natureza era ainda constante.

Percebendo que, nesse ambiente, a sobrevivência da política social depende sempre da catalisação entre a produção de riqueza e a melhora na perspectiva de existência, os ordoliberais identificaram que no liberalismo clássico, o papel de fiel da balança dessa catalisação recaiu sobre o laissez-faire, um instrumento

\footnotetext{
51 "Segundo Eucken, o 'quadro' é o produto da história dos homens, de modo que o Estado pode continuar a moldá-lo por uma política ativa de 'ordenação'; o 'processo' da atividade pertence à ação individual, por exemplo, a iniciativa privada no mercado, e deve ser exclusiva e estritamente regida pelas regras de concorrência na economia de mercado. "(Dardot; Laval, 2016, pp. 113-114)
} 
temerário $^{52}$. O laissez-faire, nessa jornada, figurou como uma faca de dois gumes, pois ao mesmo tempo em que é o fiel escudeiro da sociedade enquanto defesa contra o intervencionismo, será também a causa do fracasso do liberalismo. Isso porque o laissez-faire, em tempos pré-revolução industrial, conseguia dar conta da equação produção de riquezas x perspectivas de existência. Quando, porém, a revolução chega, o modelo laissezfairiano desaba em razão de um desencontro entre o ambiente histórico no qual o princípio foi gestado e as consequências resultantes da revolução industrial à sociedade.

A revolução industrial foi a revolução da riqueza, que passou a ser produzida em regimes e quantidades revolucionárias. Nesse sentido, apesar da enorme circulação de riqueza, o liberalismo não soube sintetizar as profundas modificações que a revolução industrial produziu nos horizontes sociais europeus: esvaziamento dos campos com o êxodo rural, surgimento de uma nova norma condutora do trabalho (o regime assalariado), num novo ambiente (a fábrica) e uma nova classe: o proletariado, fruto da massificação dos povos ${ }^{53}$. A produção maximizada de riqueza foi acompanhada pela desolação como perspectiva de existência, representada pelo título "proletário" e todas as precariedades de estilo.

O proletariado é o conjunto de filhos espúrios da revolução. São sujeitos produzidos e enjeitados afetados pela separação drástica e umbilical que o homem mantinha com o seu ambiente natural campestre. Sua condição de proletariado dominado pelo diretivismo fabril o esvazia da sua própria humanidade, satisfação e amor-próprio. Essa classe disciplinada, frustrada e recalcada, separada de si mesma, serviu de matéria prima às investidas socialistas contra o liberalismo,

\footnotetext{
${ }^{52}$ Contra uma valorização naturalista do laissez-faire, Röpke escreve:

"Não é empenhando-nos em não fazer nada que suscitaremos uma economia de mercado vigorosa e satisfatória. Muito pelo contrário, essa economia é uma formação acadêmica, um artifício da civilização; ela tem em comum com a democracia política o fato de ser particularmente dificil e pressupor muitas coisas que devemos nos esforçar obstinadamente para atingir. Isso constitui um amplo programa de rigorosa política econômica positiva, com uma lista que impõe tarefas a serem cumpridas." (Röpke, apud Dardot; Laval, 2016, p. 105)

53 Sobre uma perspectiva foucaultiana e marxista do papel da norma como produtora de subjetividades e de elemento disciplinar fabril no momento da Revolução Industrial, fiz uso da obra de Macherey (2014). Na perspectiva ordoliberal e sua "crítica" à formação do proletariado como um fator destrutivo do liberalismo, remeto ao capítulo 3 da obra de Dardot e Laval (2016)
} 
derrubado aos poucos pelas revoluções do século $\mathrm{XIX}^{54}$, num processo que começou com a revolução francesa, encabeçada por esse fator novo, le Peuple Souverain, que inexistia no léxico político de então.

A destituição do laissez-faire promoveu a sua substituição por outro agente catalisador, fruto da "revolução popular": o Estado social. Sob o pretexto da fundação de uma ordem social assistencialista e protetiva ao proletariado, o Estado reafirmou para si a missão diretiva do mundo social e econômico, porém longe de solucionar a questão. O Estado antes perpetuou a situação proletária sob uma nova forma de capitalismo, não mais liberal, mas servil. Não ofereceria remédios, apenas analgésicos, pois a manutenção da doença significaria a sua própria manutenção.

Essa é, em abreviada exposição, a história do liberalismo clássico segundo os ordoliberais.

Como cura, os ordoliberais montam uma receita que casa a origem teórica do problema e os materiais resultantes da sua experiência histórica. Clamavam pelo retorno do homem a si mesmo por meio da resolução da questão do proletariado e a reestruturação da economia sob uma perspectiva liberal no sentido de "nãodirigida". Sabiam, todavia, dos problemas da liberdade absoluta e da incontinência das aventuras industriais, e por isso, os ordoliberais unem as vantagens da economia livre, garantida pela concorrência, com a eficiência prática da intervenção do Estado enquanto forma de regulador da vida (mas condenando seu papel como diretor) para traçar uma estratégia de intervenção estatal necessária e benéfica somente no aspecto referente à manutenção da concorrência livre e justa como gramática da economia social.

Nessa perspectiva, são evidentes as contribuições de Walter Eucken e Wilhelm Röpke no oferecimento de um novo arcabouço intelectual para instruir o papel do Estado e a sua participação na esfera social, mas também o resgate do Homem alienado à natureza. O primeiro passo teórico a ser dado, naturalmente, é

\footnotetext{
${ }^{54}$ Walter Eucken enfatiza o papel que a Revolução Francesa e a ideia de soberania do povo desempenharam no papel de surgimento do Estado Interventor e no desabamento do Liberalismo. A ideia de povo soberano, segundo o autor, só foi possível graças à massificação promovida pela Revolução Industrial, que, arrancando os sujeitos de suas "raízes naturais" (os laços tribais, comunais, etc) os condensou nessa categoria "artificial e agressiva" do "Povo Soberano". (Eucken, 1956 , p. 262)
} 
negar a naturalidade tanto do Estado, quanto do liberalismo, para a partir daí tratálos como elementos que, se não são humanos, tiveram gênese humana - foram criados; não surgiram, e por isso são passíveis de serem instrumentalizados. "Parte do domínio do artificio, não da natureza" (Dardot; Laval, 2016, p. 105) O segundo passo é reconhecer, no ambiente social, uma alocação contingente da chamada hierarquia social, composta de vários escalões de grandeza e destaque dentro da sociedade, sendo o Estado um desses escalões, junto à igreja, à comuna, à associação, etc.. Esse último aspecto também não é natural, mas é fruto espontâneo da sociedade humana ${ }^{55}$. Constatando que nem o Estado, nem as instituições e nem o liberalismo são naturais, e portanto pré-humanos, os ordoliberais não fazem disso um argumento destrutivo, mas antes se aproveitam da experiência deixada por esses elementos para construir uma nova sociedade.

É com Eucken ${ }^{56}$, segundo Dardot e Laval, que surgem dois conceitos exemplificadores do ordoliberalismo: o de "ordem econômica" (Wirtschaftsordnung) e o de "ordem da economia" (Ordnung der Wirtschaft), que são didáticos para evidenciar o plano Ordoliberal para o Estado e para a Sociedade. A ordem econômica é um dado fático, resultado das experiências econômicas e do acúmulo de produtos histórico por ela produzidos, somada às particularidades sociais, culturais, religiosas e demais elementos capazes de influenciarem ou

\footnotetext{
${ }^{55}$ Nesse sentido, conforme Röpke:

Partindo de cada indivíduo e retornando à central estatal, o direito original encontra-se no escalão inferior, e cada escalão superior entra em jogo subsidiariamente, no lugar do escalão imediatamente inferior, apenas quando uma tarefa ultrapassa o domínio deste último. Constitui-se, assim, um escalonamento do indivíduo, além da talha e da comuna, até o cantão e, finalmente, até o Estado Central, um escalonamento que, ao mesmo tempo, limita o próprio Estado ao qual ele contrapõe o direito dos escalões inferiores, com sua esfera inviolável de liberdade. Portanto, nesse sentido largamente entendido da "hierarquia", o princípio da descentralização política já implica o programa do liberalismo em seu sentido mais estendido e mais geral, um programa que, desse modo, faz parte das condições essenciais de um Estado são, de um Estado que estabelece para si mesmo as limitações necessárias e, respeitando as esferas livres do Estado, adquire sua saúde, força e estabilidade. (Röpke, apud Dardot; Laval, 2016, p. 110)

${ }^{56}$ Esclarecimento metodológico. Dardot e Laval frequentemente fazem uso e citação da grande obra de Eucken "Die Grundlagen der Nationalökonomie, (Fundamentos da Economia Nacional)", onde se desenvolve o melhor os conceitos de Ordem Econômica e Ordem da Economia. Lamentavelmente não encontrei, nem em português e nem em qualquer outro idioma que eu domine, a referida obra de modo que tive que me servir dos trechos e raciocínios apresentados por Dardot e Laval. Quanto a outra obra de Eucken, que os autores não citam mas que julguei de estudo interessante - a saber "Grundsätze der Wirtschaftpolitik (Fundamentos de Política Econômica)", pude fazer contato direto através de uma tradução espanhola, constante na bibliografia, e daí a cito diretamente. O mesmo ocorreu com o Civitas Humana de Röpke, estudado diretamente com base numa tradução inglesa.
} 
sofrerem influência do status econômico da sociedade. Ordem, aqui, compreende o ethos social.

A ordem da economia já tem um sentido normativo. Constitui não o ser econômico, mas o plano (ou projeto) diretivo da ordem econômica, em direção ao estatismo, ao planismo e ao coletivismo no caso dos socialistas; ou em direção à preservação da liberdade, da concorrência e, acima de tudo, da dignidade humana, inscrito na estrutura política da sociedade, no caso dos ordoliberais. Deve ser o quadro institucional previamente arquitetado para assegurar o funcionamento da ordem econômica. Aqui o direito ganha enorme importância como ordenador da ordem econômica para evitar seus excessos e efeitos colaterais desagradáveis, como monopólios, cartéis ou a formação da miséria proletária. Esse quadro institucional é uma amostra que a fobia do Estado mencionada por Foucault é menor nos alemães do que nos austroamericanos, dado que a intervenção do Estado na ordem econômica, desde que feita de maneira salutar, é necessária. É principalmente por meio da ordem da economia que são postas as regras do jogo para que a ordem econômica aconteça de maneira salutar. Nesse sentido, Eucken escreve sobre a ordem da economia como condição para a ordem econômica, e não a segunda como base para a primeira ${ }^{57}$ :

\begin{abstract}
Falsa seria a visão segundo a qual a ordem econômica seria como a infraestrutura (der Unterbau) sobre a qual se ergueriam as ordens da sociedade, do Estado, do direito e as outras ordens. A História dos tempos modernos ensina tão claramente quanto as épocas mais antigas que as ordens do Estado ou as ordens jurídicas também têm influência sobre a formação da ordem econômica. (Eucken apud Dardot; Laval, 2016, p. 103) ${ }^{58}$
\end{abstract}

\footnotetext{
${ }^{57}$ Sobre isso, cumpre lembrar o que Eucken escreve alhures, em outro momento, no qual afirma que as fronteiras entre Ordem da Economia e Ordem Econômica não são estanques, ao falar da reciprocidade da influência do planismo interventivo da economia pelo Estado e sua recepção pela sociedade:

"También en el orden económico y social existe este efecto recíproco. No son sólo los métodos de la dirección económica los que conforman la estructura social, sino que tanbién la estructura social repercute sobre la dirección económica. Una capa social de labradores fuertemente enraizada e independiente opone una extraordinaria resistencia al control de la producción agrícola por las autoridades centrales, según muestra la experiencia. Los labradores quieren llevar a cabo los planes económicos pariculares, y la direccíon económica centralizada encuentra aquí unos ciertos límites. 'Constituición del Estado', 'constituición económica' y 'orden social' se encuentran siempre en una dependencia reciproca." (Eucken, 1956, p. 264. Grifei)

${ }^{58}$ Eucken permanece firme ao negar ao direito qualquer aspecto natural como ao gosto dos liberais clássicos. O Direito (leia-se a forma jurídica e o ordenamento) compõe a ordem da economia, mas é considerado como tal na qualidade de produto dos fatores sociais e políticos, e dessa forma ocupa um lugar "abaixo" do Estado e das fontes reais do poder no momento de instituição da ordem da economia e da direção da ordem econômica, sendo somente um instrumento da ordem da economia, e não um dos seus fatores. Ou seja, a forma jurídica pode ser "contornada" por fatores políticos e
} 
Desse modo, muito se evidencia sobre os ordoliberais alemães, resumidamente: negação do naturalismo, tanto do liberalismo quanto do laissezfaire, compreensão histórica da crise do liberalismo, aproveitamento das experiências institucionais deixadas pelo processo histórico (Eucken) e a necessidade de promover o retorno do homem a si mesmo (Röpke). A separação entre o aspecto fático "ordem econômica" e a possibilidade de moldá-la por meio do reto uso do aparato normativo "ordem da economia" encerra o núcleo duro do marco teórico ordoliberal para a construção de uma sociedade livre, consubstanciada na concorrência e respeitadora da "hierarquia social natural", sendo possível que o Estado intervenha para garantir seu bom funcionamento. Esse raciocínio é possível através da noção de que as diferentes esferas do mundo da vida - a social, a política, a econômica, a jurídica, etc. - são interdependentes.

Estabelece-se, portanto, o papel do Estado como instrumento construído para um determinado fim, e erguido sobre princípios constituintes indispensáveis para o seu regular funcionamento. O Estado é Forma, dotado de função de ordem e regulação, e sua construção deve obedecer à geometria prescrita nesses princípios que garantem o arcabouço estatal como forma onde o social e o econômico serão "engaiolados"59. O quadro está estabelecido. Cumpre falar do processo.

O processo compreende o funcionar do mundo da vida, da realidade humana nas esferas da vida, tal como sempre foi. O processo inserido no quadro quer dizer que as condutas que os sujeitos praticarão, as decisões e atitudes que empreenderem não serão coagidas e nem conduzidas. Antes estarão inscritas numa perspectiva de livre-ação e concorrência, pois é a concorrência que garante a liberdade por meio da livre formação dos preços. A função do quadro não é jamais intervir no processo portanto, mas tão somente garantir o bom funcionamento do processo, eliminando ou corrigindo nele tudo aquilo que ameace a concorrência. $\mathrm{O}$ procedimento de formação do quadro é de natureza política, e a priori, enquanto que o de formação

sociais para reconfigurar a ordem econômica apesar do Direito. Esse é um ponto no qual acredito que a análise de Dardot e Laval foi silente, e me cumpriu mencionar. Nesse sentido, confira-se o exemplo que Eucken faz do "Estado Federal em guerra" em Eucken, 1956, p. 262

${ }^{59}$ Esses princípios são: Princípio da estabilidade da política econômica; princípio da estabilidade monetária; princípio dos mercados abertos; princípio da propriedade privada; princípio da liberdade dos contratos e princípio da responsabilidade dos agentes econômicos (Dardot; Laval, 2016, p. 113) 
do processo é de natureza econômica, e a posteriori. Para a construção do quadro, se estabelece uma política de ordenação, que, levando em conta os princípios constitucionais, promoverá o arcabouço e a estrutura de vigilância do processo. Uma vez concluída essa etapa, o jogo do processo pode ter início, de modo que a partir de então, a dobra do quadro sobre o processo terá natureza também política, mas de regulação, tão somente. De ato de governo das coisas. O bom governo, nesse caso, é o que menos intervém não porque intervir menos seja a política a ser feita (como no liberalismo clássico) mas porque terá menor necessidade de intervir em razão da perfeita adequação entre a ordem da economia - inscrita no Quadro pela política de ordenação formadora - e a ordem econômica, consubstanciada no processo.

Para resumirmos, a política de ordenação intervém diretamente no 'quadro' ou nas condições de existência do mercado de modo a realizar os princípios da constituição econômica; a política reguladora intervém não diretamente no 'processo' em si, mas por intermédio de um controle e de uma vigilância cujo intuito é afastar todos os obstáculos ao livre jogo da concorrência e, assim, facilitar o 'processo'. (Dardot; Laval, 2016, p. 115)

Desse modo, o ordoliberalismo figura como um planejamento não só econômico, mas também político, dotado de um caráter constitucional, e tendente a controlar o coletivo de sujeitos para evitar o inadequado, o excessivo, o indesejável e o nocivo por meio de um processo notoriamente político. Para que esse todo esse projeto funcione, para que os sujeitos ajam exatamente conforme o esperado, é necessário cunhar, no âmbito da política, um conceito de sujeito, com determinadas características, e que se comporte no processo conforme exatamente desejado, de modo a evitar ao máximo qualquer regulação que se faça necessária. Será preciso a construção de uma norma geral de controle dos grupos de sujeitos, uma norma biopolítica, sobre a qual se escreverá mais a frente.

\section{3}

\section{Lippmann, Mises, Hayek}

Conforme já expressei em determinadas passagens, pretendo construir o cerne do raciocínio do trabalho a partir das experiências abertas pelos sujeitos. O que procurei expor sobre os ordoliberais alemães não teve por objetivo fazer uma recontagem histórica apenas para fins de ilustração. Dali procurei extrair algo, a partir da experiência ordoliberal, para, junto a outros fatores, fundar meu argumento. Se, porém, tomei os alemães como um todo, tratando de von Rüstow, 
Röpke e Eucken como homogêneos (apesar de saber que, se estudados individualmente, existem diferenças entre os seus pensamentos), não pretendo, nesta etapa, tratar dos austroamericanos como contraparte dos ordoliberais, como se fosse apresentar "o outro lado" do colóquio Lippmann num processo dialético. Ao contrário, pretendo reforçar o que apresentei até agora com as contribuições de outros três pensadores; dois dos quais, por acaso, são "austroamericanos". Não vou falar aqui, portanto, dos austroamericanos, mas de três pensadores isolados: Walter Lippmann, Ludwig von Mises e Friedrich Hayek.

Walter Lippmann (1889-1974) era jornalista e ensaísta, nascido em Nova York. Durante a juventude circulou por grupos socialistas antes de se associar ao liberalismo e à sua defesa. Teve considerável envolvimento com a política americana da década de 30, sendo crítico do New Deal. Era um intelectual respeitado, e sabia construir amizades apesar de eventuais diferenças ideológicas. A prova disso foi a amizade duradoura que travou com Keynes, a partir de 1920.

A contribuição de Lippmann já foi antecipada no início desse capítulo. Sua preocupação final é com a construção da Grande Sociedade, mas, antes disso, surgiu a questão incidental da crise do liberalismo clássico (the debacle of Liberalism), que emergiu do triângulo definido pelos três pontos-chave: laissez-faire, divisão do trabalho, e revolução industrial. Sendo o livro de Lippmann o pivô do colóquio, é natural que esses três pontos apareçam frequentemente para explicar a crise, conforme recém exposto no tocante ao ordoliberalismo. Varia no entanto a interpretação que se dá a cada um deles e principalmente no papel atribuído ao Estado enquanto provocador ou corretor da crise.

"A hundred years after Adam Smith published The Wealth of Nations the liberal philosophy was decadent" (Lippmann, 1943, p. 183). É com essa amável afirmação que Lippmann inicia sua explicação. O liberalismo não começou, por certo, com Adam Smith; antes disso já estava implantado como ideal, ainda que em estado embrionário, em toda a sociedade mercantil, sob a fórmula do laissez-faire como perspectiva de remoção das barreiras à livre-troca de mercadorias, de saberes, de experiências. Esse ideal ficou "cozinhando" nas comunas, guildas, grêmios mercantis, associações comerciais, bolsas, ou seja, entre a classe mercante dos fins da Idade Média à segunda metade da Idade Moderna, até eclodir em 1776: ano da 
revolução americana e da publicação de A Riqueza das Nações. A partir de então, o ideal revolucionário laissezfaireano virou princípio político aplicado na prática. (Lippmann, 1943, p. 185)

É difícil tratar o laissez-faire como causa do liberalismo e vice-versa. Lippmann prefere tratá-lo em um sentido duplo, sem se preocupar em responder à questão. Desse modo, ele figura 1) como ideal revolucionário histórico de construção do liberalismo, e nesse sentido, sua causa "ideológica"; 2) o princípio de operação do liberalismo, enquanto política prática e meio de construção para uma sociedade livre, com mercado livre de intervenções nocivas (porque Lippmann admite determinadas circunstâncias nas quais a intervenção é necessária). Desse modo, o liberalismo pode ser definido, conforme o autor, da seguinte maneira: é uma forma de governo que guarda relação com a experiência histórica da divisão do trabalho e da economia de mercado como reguladora daquela ${ }^{60}$. A economia de livre mercado é salvaguarda e resultado histórico da divisão do trabalho, pois permite que o sujeito troque o fruto do seu trabalho por aquilo que necessita na medida da sua necessidade ou vontade ${ }^{61}$.

Que Lippmann vai indicar no laissez-faire a origem da crise já se sabe, conforme exposto páginas acima. Mas, segundo seu entendimento, o problema não é o laissez-faire em si (como argumentariam os ordoliberais), mas sim o que foi feito dele. Lippmann não poupa energias na crítica ferrenha ao culto naturalista à "mística do mercado", e identifica nessa ingenuidade metafísica a raiz do problema. Tudo isso já se sabe, mas é preciso explicar como esse problema foi gestado.

A construção de uma perspectiva clássica no laissez-faire em um escopo naturalista obedece à lógica de espaço natural x espaço artificial. $\mathrm{O}$ mercado, enquanto espaço de troca de experiências, saberes e produtos, obedeceria à lógica da natureza e do racionalismo inerente ao homem enquanto parte da mesma

\footnotetext{
60 "It was the historic mission of liberalism to discover the significance of the division of labor; its uncompleted task is to show how law and public policy may be best adapted to this mode of production which specializes men's work, and thereby establishes an increasingly elaborate interdependence among individuals and their communities throughout the world." (Lippmann, 1943, pp. 174-175)

61 "The liberal conviction that there can be no other satisfactory regulator of work, investment, and consumption rests on the realization that when men specialize their labor, they must live by exchanging the product. " (Lippmann, 1943, p, 175)
} 
natureza. Aqui se rememoram as tradicionais teorias jusnaturalistas lockeanas e suas perspectivas do mercado como elemento formador de verdade ${ }^{62}$. De outro lado, o artificial, corporificado na figura da ordem jurídica ${ }^{63}$ como forma emanada das deliberações e construções humanas, de aspecto normativo e não componentes da ordem natural. Sendo o mercado uma esfera natural, ele tem a função de promover um marco, consubstanciado no preço, para a tomada de decisão dos sujeitos que nele transitam, seja comprando ou vendendo, de modo a orientar racionalmente as suas condutas conforme aquilo que é necessário ou conveniente. Para que o mercado cumpra essa função, é evidente que o sistema de preços deva se formar naturalmente, isto é: sem a perturbação por intervenções por parte de sujeitos que busquem provocar um determinado resultado. Nada novo até aqui.

Enquanto o laissez-faire figurou como política defensora da livre formação de preços no mercado, ele cumpriu sua função de defensor da liberdade do mercado (isso é, a vedação à intervenção) como condição para o progresso social por meio da divisão do trabalho e da maximização da satisfação. Quando os latter-day liberals começam a encarar o laissez-faire sob uma perspectiva cientificista exagerada, no sentido de ver todo objeto da Lei como intervenção, e portanto ameaça à liberdade, a ordem liberal decaiu. Lippmann explicaria que essa derrota se deu não somente em razão do dogmatismo fanático dos liberais contra qualquer intervenção, mas também pela sua incompreensão de que a divisão do mundo entre natureza e lei é uma ideia falaciosa na sua essência. O erro dos economistas clássicos foi acreditar que tinham uma fotografia do mundo nas mãos e esquecer da câmera. A pregação da naturalidade do mercado ignora que os institutos típicos da livre troca, como liberdade, mercadoria, ato de comércio, propriedade e tantos outros são produto da Lei, e não da natureza, que aliás, em termos de mercado, nunca existiu. $\mathrm{O}$ mercado nunca foi realmente natural no sentido real da palavra, acrescentaria Lippmann. Não existe nem mercado e nem divisão do trabalho sem o

\footnotetext{
${ }^{62}$ Sobre isso já foram gastos rios de tinta e a literatura é enorme. É interessante lembrar desde já, todavia, a intervenção de Foucault em Nascimento da Biopolítica, na aula de 17 de janeiro de 1979, sobre o papel que o mercado desempenhará como instrumento "formador da verdade" no âmbito da economia política e do despotismo como formação da razão governamental do Liberalismo a partir do século XVIII. É disso que se está falando quando se alça o mercado a uma categoria "natural". Voltarei a esse raciocínio no próximo capitulo.

${ }^{63}$ Lippmann usa o termo Law. Na tradução brasileira da obra de Dardot e Laval, o termo Law foi traduzido a partir de Loi como Lei. Optei por utilizar "ordem jurídica" por me tradução seria mais adequada à ideia.
} 
auxílio do universo jurídico. Não há troca, lucro, ou titularidade sem a construção necessária desses entes na linguagem jurídica ${ }^{64}$.

A crença ingênua na naturalidade do mercado e da divisão do trabalho, percepção de qualquer forma de direito como intervenção, a ignorância da construção jurídica por trás dos conceitos mercantis geraram uma postura agressiva dos economistas clássicos e dos latter-day liberals contra qualquer política institucional para com o mercado, sob a acusação de intervenção perturbadora do laissez-faire. Essa postura agressiva e ignorante impediu que as necessidades do mercado e da produção de riqueza fossem acompanhadas pela inovação jurídica de regulação do processo por meio da Lei, e preparou o caminho para a intervenção direta no controle da formação dos preços como tentativa de cura dos males que a crença no misticismo laissezfaireano provocou. Eis aí o surgimento do grande dogma: só a intervenção salva.

É importante ressaltar, contudo, que a intervenção é a conduta deliberada de um sujeito participante do mercado de controlar a condução do processo mercadológico por meio da tentativa de formulação do preço final. São várias as estratégias que podem ser usadas para influenciar na formação do preço (e das condutas que daí seguem por parte dos outros sujeitos). No entanto, ressalta-se a expressão "sujeito participante do mercado" para relembrar que a tentativa do controle da formação do preço era ameaçada não só pela inflação do Estado, mas também pela inflação do próprio capital. Não é só o ideal planificador estatal que se aproveita do encanto dos liberais pelo laissez-faire. Também o ideal monopolizador dos cartéis busca determinar o preço e a conduta, aproveitando-se da proibição da intervenção estatal para agir livremente. Trocando em miúdos: Lippmann tem dois inimigos a combater.

\footnotetext{
${ }^{64}$ Como americano, Lippmann era obviamente mais familiarizado com a tradição anglo-saxã do Common Law, o que facilita entender o porquê do autor não ver o Direito de uma maneira tão aversiva quanto Hayek e von Mises, por exemplo, que conviveram com a tradição romanogermânica. A ideia do costume material como fonte do direito, e da norma jurídica como afirmação das práticas sociais é bem mais palatável à agenda liberal de Lippmann do que qualquer predicado que se pretenda afirmador do espírito da norma, quando essa é de caráter abstrato e exige uma aplicação da regra geral aos casos particulares de forma dedutiva. A prova disso era a desconfiança que Lippmann tinha da capacidade dos órgãos legislativos representativos de emitirem normas que não fossem tendentes a intervenções inadequadas.
} 
O problema do processo de intervenção planificadora vai além do prejuízo à livre formação do preço. A mentalidade por trás de todo processo planificador é a falácia de que o preço justo pode ser estabelecido deliberadamente, e que é possível a um ente interventor dominar todo o coletivo de práticas, de saberes e de condutas que vão interferir na formação do preço final. Por parte do Estado é óbvio onde se começa: a partir das críticas sociais oriundas dos bolsões de miséria abertos pelo capitalismo industrial, a cegueira dos economistas clássicos e da elite política a esses problemas (e à sua origem), proibindo qualquer interferência na ordem econômica, o descontentamento, a revolta, a rebelião e a ruína do Estado pelos socialistas. O resultado será o totalitarismo autoritário (já expliquei que a expressão não é pleonástica), consubstanciado nas suas variações fascista ou comunista ao modelo soviético.

Eis aqui alguns pontos que merecem ser destacados no pensamento de Lippmann antes de avançar para outros: a concentração de poder sobre o mercado por parte do capital é fruto de ganância; por parte do Estado é ingenuidade, e esta tão perigosa quanto a dos latter-day liberals. Isso porque, em que pese a necessidade de se valorizar o papel histórico da lei na preservação do liberalismo, o processo de divisão do trabalho e de formação do preço na circunstância do mercado obedece a lógicas próprias a partir das trocas nele realizadas. Qualquer tentativa de controlar o processo acarretará em imediato fracasso (pois é impossível ter consciência de todos os fatores e condutas dentro do processo), e incorrerá em uma menor liberdade e maior intervencionismo, maior totalitarismo. A intervenção inaugural é o primeiro passo para o caminho para a servidão (uma expressão utilizada por Lippmann antes de Hayek) que culminará no endurecimento final do coletivismo, seja pela via fascista ou comunista. Intervir é uma atitude ingênua, irresponsável, e economicamente pueril, apesar de eivada de sentimentos nobres. Já se disse uma vez que "o caminho para o inferno está pavimentado com boas intenções", mas essa máxima não é de Lippmann, nem de Hayek.

Lippmann não é um pensador de transição entre os ordoliberais e os austroamericanos. Evidentemente comungará de pensamentos mais próximos a tal o qual perspectiva, mas é difícil encaixá-lo. É preferível fazer como Audier e Reinhoudt e atribuir-lhe um status de originalidade na teia intelectual do colóquio (Audier; Reinhoudt, 2018, p. 63). Se por um lado criticava o laissez-faire puro e 
clamava pela necessidade de algo além dele para justificar a agenda do liberalismo, criticava com veemência qualquer intervenção estatal na ordem econômica, sob o risco de condução ao totalitarismo.

Diferente era a perspectiva de von Mises, para quem ou há liberdade de mercado, ou há ditadura do Estado. Ludwig von Mises (1881-1973) nasceu no que hoje é a Ucrânia, e à época parte do Império Austro-Húngaro. Sua educação cultural foi germânica, portanto, e completada na Universidade de Viena. A educação econômica de Mises se deu com as contribuições de Carl Menger (1840-1921), que o incentivou nas teorias dos cálculos econômicos. O economista, todavia, é mais marcante (pelo menos para este trabalho) pela defesa que faz da praxeologia como ciência básica sobre a qual toda ação econômica deve estar edificada.

Mises desloca o tema da defesa da liberdade, proporcionada pelo livre mercado, da esfera política para a esfera filosófica da epistemologia, de maneira que, num primeiro momento do colóquio, o autor está mais preocupado com a conduta econômica e os modos que favorecem ou impedem sua salutar performance. Ele se dedicará, em vários trabalhos, à análise política do liberalismo, do socialismo e do fascismo. Tais obras são conhecidas, mas menos citadas do que sua obra mestra $A$ Ação Humana, na qual ele se dedica de maneira mais incisiva à praxeologia, apesar da publicação do livro só ter ocorrido posteriormente ao colóquio, em 1949. Esclareço então, desde logo, que o Ludwig von Mises que vou tratar aqui é de um autor mais maduro, posterior ao colóquio, quando as ideias até então cruas de 1938 já ganharam formas mais definidas onze anos depois, dado que estou preocupado em estabelecer experiências neoliberais, e não escrever uma micro-história do colóquio Lippmann.

A posição de Mises é radical. Não existe possibilidade de intervenção no livre mercado, pois o mercado não será livre. Dito de outra forma, não há mercado livre onde há presença econômica do Estado ${ }^{65}$. Isso porque von Mises atribuirá ao

\footnotetext{
${ }^{65}$ Sobre esse ponto, confira-se Dardot; Laval, 2016, p. 137 e p. 142. Confira-se também Mises, 2007, p. 764. Tal posição maniqueísta, levada posteriormente ao exagero dentro do pensamento econômico neoliberal, será a gênese do ideal anarcocapitalista de Murray Rothbard. Uma discussão sobre anarcocapitalismo é complexa, leva tempo e páginas e foge totalmente do presente trabalho, mas cumpre lembrar da contribuição intelectual de von Mises ao ideal libertário por meio dessa fórmula radical.
} 
mercado o status duplo: ele é tanto um ambiente onde as trocas ocorrem e as escolhas são feitas de maneira livre, como é também um processo autoconstrutivo de formação do sujeito racional, o empresário de si mesmo. O episódio da constituição histórica do mercado e sua operação obedecem a critérios próprios e inerentes ao próprio processo mercadológico, impossíveis de se submeterem a um controle. A tese miseana portanto é negar ao Estado qualquer direito ou permissão para intervir no processo de construção de uma ordem comprometida com a liberdade humana. Conforme explicado acima, o argumento percorre um veio apriorístico ao político, envolvendo epistemologia e praxeologia antes de adentrar em outros conceitos como economia, mercado, laissez-faire e etc. É aí, portanto, que se deve começar.

Não se pode falar de economia, ou pelo menos de economia enquanto ciência, e ciência prática, sem tratar da questão da praxeologia, ou seja, de uma teoria geral da ação humana. (Mises, 2007, pp. 1-3). A descoberta desse feito revolucionou a ciência econômica porque explorou as bases profundas nas quais se assentam todos os modelos econômicos saudáveis que já existiram, diz o autor. Por muito tempo, o homem buscou justificativas epistemológicas para todas as ciências, ora remetendo-as ao divino, ora às instituições morais humanas. A questão da economia só começa a ser encarada de maneira mais séria quando se identifica o primeiro movimento que põe o aparato econômico em movimento: a escolha. A escolha feita pelo sujeito agente no mercado é o motor da liberdade.

Para entender o pensamento praxeológico miseano e a sua posterior aplicação à economia, é necessário esclarecer o que é ação, o que é escolha e o que é humano, para se poder falar, então, de Ação Humana. O raciocínio de Mises é complexo, confuso e por vezes contraditório ${ }^{66}$. Por isso, cumpre explicar em partes. Ao falar da ação que será a Ação Humana (causa final), vou dividir entre Ação e ação, sendo aquela a Ação da qual Mises trata, e esta a ação enquanto sentido normal do termo ${ }^{67}$.

\footnotetext{
${ }^{66}$ Conforme se verifica na afirmação da página 12 , segundo a qual a ação inconsciente é ação, e toda ação é intencional; e a afirmação da página 19, segundo a qual a ação humana é sempre racional.

${ }^{67}$ Ressalto que essa divisão é minha, e a empreguei apenas para facilitar a explicação do conceito. Von Mises não faz essa distinção.
} 
A ação é toda atitude humana que provoca um resultado perceptível no mundo material. Por trás dessa definição que parece básica e simplória há que se considerar que a ação não precisa ser necessariamente "ativa", podendo ser uma “ação passiva”, pois “o fazer nada também é ação!” (Mises, 2007, p. 13). A ação também não exige como pré-requisito que seja consciente ou inconsciente. Naturalmente só as ações conscientes podem ser chamadas de racionais, e terão maior peso, mas as ações inconscientes ou inconsequentes são igualmente ações, pois provocam resultados materialmente perceptíveis. Os atos de comprar e vender são ações, e por essência, racionais e conscientes. O assassínio também é ação. Pode ser consciente, como o matador de aluguel ou em legítima defesa; mas um homicídio cometido por uma pessoa descontrolada não deixa de ser ação, ainda que realizada de maneira passional e inconsequente em razão de eventuais circunstâncias.

A escolha é a agência humana. É a ação que, analisada, calculada e ensaiada, toma corpo e é posta em prática almejando um determinado fim. Percebese aqui a sutil diferença entre ação e agência no pensamento de Mises ${ }^{68}$. A agência é ação deliberada buscando um determinado objetivo e envolve duas operações fundamentais: a determinação consciente de um objetivo e o cálculo prático para obtê-lo, o que implica, portanto, numa delimitação específica do resultado desejado e o balanceamento dos riscos e chances de fracasso inerentes ao feito. Naturalmente, ao se falar de escolha, fala-se de opções. O sujeito que escolhe deve, então, tomar uma atitude binária que envolve acolher uma opção e rejeitar a outra, e nesse processo de escolha, deve sempre ter em mente o supracitado objetivo buscado, riscos advindos da consequência e a determinação de se obter o resultado desejado. (Mises, 2007, p. 12)

O último elemento da Ação Humana é o sujeito. O homem praxeológico miseano é o indivíduo que acima de tudo entende as relações de causa e efeito da teoria da Ação Humana, ou seja, é o sujeito capaz de perceber que, "suposta a constância das condições conhecíveis para um determinado resultado, a ação adequada a ser tomada, é essa: (ação X)". Note-se ação adequada, e não ação

\footnotetext{
${ }^{68}$ Conforme o autor: "Human action is purposeful behavior. Or we may say: Action is will put into operation and transformed into an agency, is aiming at ends and goals" (Mises, 2007, p. 11)
} 
correta, pois a praxeologia é evidentemente uma razão prática, e não moral. A decência da ação tomada está diretamente ligada à satisfação do objetivo pretendido, e não a uma condição ética pré-determinada para a sua condução. ${ }^{69} \mathrm{O}$ sujeito se vê na oportunidade de agir sempre que se vê numa situação individualmente desconfortável ou vislumbra no horizonte um estado de satisfação realizável e melhor do que o status quo. (Mises, 2007, pp. 13 e 16). Ou seja, a Ação é movida a contentamento e satisfação do indivíduo com alguma esfera dele com ele mesmo. Esse indivíduo racional, agente e ambicioso não se enquadra nas categorias do homo sapiens filosófico, ou do homo oeconomicus da economia clássica. Ele é Homo Agens: o indivíduo que constrói a si mesmo e ao mundo por meio da Ação Humana. ${ }^{70}$

Estabelecido esse resumo da Ação Humana - composta por ação, agência e sujeito - se pode fazer a ilação com seu aspecto econômico para explorar melhor a contribuição de von Mises ao debate neoliberal.

A análise que Mises e Hayek, posteriormente, farão do mercado muda o tratamento dado ao tema desde a economia neoclássica, a saber, a ideia de que o mercado é uma esfera natural de trocas, que seu processo é objetivo e estático. Mises vai contra tudo isso. Primeiramente nem o mercado e nem o laissez-faire são naturais, e nisso todos concordam. A crítica que se fará contra o aspecto estático e objetivo do mercado reside na própria Ação Humana.

A economia neoclássica trabalhava com uma perspectiva de equilíbrio no mercado construída sobre a concorrência perfeita, de maneira que o mercado saudável era aquele onde o preço estava perfeitamente ajustado e oferta e demanda estavam em harmonia. Havendo alguma perturbação, a ordem mercadológica

\footnotetext{
69 "Human action is necessarily always rational. The term rational action is therefore pleonastic and must be rejected as such. When applied to the ultimate ends of action, the terms rational and irrational are inappropriate and meaningless. The ultimate end of action is always the satisfaction of some desires of the acting man" (Mises, 2007, p. 19). Uma análise cuidadosa dessa passagem já permite indicar que Mises não reconhece ao mercado nenhum papel moral.

${ }^{70}$ Foucault (2008), e consequentemente Laval (2018) usam a expressão homo oeconomicus para se referir a esse sujeito empresário. Já em seu trabalho com Pierre Dardot, Laval empregará a expressão homo agens; tal como utilizada por Mises. Desse modo, atenho-me a homo oeconomicus como sujeito da economia neoclássica, e a homo agens quando for me referir ao sujeito neoliberal, empresário de si mesmo, aventureiro do mercado.
} 
deveria trabalhar para reestabelecer o equilíbrio ${ }^{71}$. Contra o aspecto estático e equilibrado da economia neoclássica, Mises defenderá uma nova perspectiva: o mercado só se desenvolve em situações de concorrência constante e inafastável, na qual a situação mercadológica muda constantemente em relação a fatores novos oriundos das ações e escolhas dos participantes; e não na concorrência estática do equilíbrio neoclássico. Essa situação de aparente desconforto tem gênese na própria complexidade do mercado, que é formado pelas reações dos participantes às ações de uns com os outros, de tal maneira que o mercado é uma rede de informações múltiplas, diversas, fracionadas que, se podem ser esperadas, nunca podem ser totalmente conhecidas. $\mathrm{O}$ "desequilíbrio" do mercado, por assim dizer, encontra sua origem da ignorância, por seus participantes, de todas as informações que estão em jogo.

Por esse motivo, o processo de formação do mercado se autoconstrói, de maneira incontrolável e autônoma, conforme passa a comportar o fluxo de mercadorias, de informações e de participantes e suas escolhas, criando uma teia de informações que devem ser descobertas pelos agentes ${ }^{72}$. Numa metáfora, seria um jogo de tabuleiro nas quais as peças postas no jogo e as possíveis jogadas não são conhecidas por todos os participantes, e conforme o número de peças, de jogadores e de jogadas aumenta, o tabuleiro cresce para comportar toda essa multiplicidade de fatores. O processo mercadológico ideal não é feito, portanto, de "calmarias", mas de "tempestades". É uma eterna convivência de fatores concorrentes - entre inovações e informações desconhecidas (ou conhecidas) - que, combinados entre si, estimularão as escolhas dos agentes do mercado. ${ }^{73}$

\footnotetext{
71 "No programa neoclássico, a concorrência sempre remete a certo estado e, nesse sentido, tem muito mais a ver com uma estática do que com uma dinâmica. [...] Toda situação que não corresponde à concorrência pura e perfeita é considerada uma anomalia que impossibilita a realização da harmonia preconcebida entre os agentes econômicos. Desse modo, a teoria neoclássica é levada a prescrever um 'retorno' às condições da concorrência estabelecidas a priori como 'normais"' (Dardot; Laval, p. 135, grifei) O mercado ideal, portanto, não pode tratar de um projeto mercadológico tendo a "harmonia" como resultado. Deve ser conduzido por "atritos" benéficos entre os partícipes do mercado para produzir uma esfera de maior troca possível de produtos e informações. Uma ordem concorrencial, mas jamais hostil. Todo desequilíbrio, desde que promovido pelos sujeitos partícipes do mercado, é bem vinda.

${ }^{72}$ Sobre a impossibilidade do controle racional da totalidade do mercado, veja também Hayek, 1988, p. 37 e também pp. 43 e seguintes.

73 "O mercado não é mais o 'ambiente' natural no qual as mercadorias circulam livremente. Não é um 'meio' dado de uma vez por todas, regido por leis naturais, governado por um princípio misterioso do equilíbrio. É um processo regulado que utiliza motivações psicológicas e competências
} 
A doutrina austríaca privilegia uma dimensão agonística: a da competição e da rivalidade. A partir da luta dos agentes é que se poderá descrever não a formação de um equilíbrio definido por condições formais, mas a própria vida econômica, cujo ator real é o empreendedor, movido pelo espírito empresarial que se encontra em graus diferentes em cada um de nós e cujo único freio é o Estado, quando este trava ou suprime a livre competição. (Dardot; Laval, 2019, p. 136)

É importante ressaltar que o processo autoconstrutor do mercado caminha junto a outro processo, o de construção do sujeito empreendedor. Esse sujeito identifica no mercado o ambiente propício à Ação Humana, ou seja, enxerga ali a possibilidade de obter um grau maior de satisfação para si mesmo a partir de determinada agência que, conforme explicado acima, exigirá a realização de escolhas tomadas a partir das informações fornecidas pelo mercado. O sujeito buscará no mercado aquilo que acredita que lhe trará conforto e, para tanto, empregará os métodos que julgar adequados à conquista do objetivo.

Tal relação entre indivíduo e mercado não necessita da interferência de terceiros. O mercado é capaz de prover as necessidades de maneira livre e adequada, desde que o sujeito empregue os meios adequados na sua agência. Para que isso se cumpra, é fundamental que o sujeito aprenda o funcionamento da economia, as tendências, as operações de risco de maneira que a sua agência seja a mais acertada. Todo esse aprendizado é realizado pela própria experiência do mercado e seu caráter pedagógico, permitindo ao sujeito que adquira uma visão empreendedora para a descoberta de oportunidades, de aspirações, de planos de ação e estratégias no ambiente de concorrência acirrada. $O$ sujeito se vê compelido ao desenvolvimento dessa habilidade empreendedora, que Dardot e Laval chamam de entrepreneurship (Dardot; Laval, 2016, p. 134), ou seja, a habilidade ou saber prático do sujeito de desempenhar sua agência da maneira mais adequada ao seu objetivo. O mercado basta ao indivíduo em todas as instâncias: ele provê a satisfação perseguida ao mesmo tempo em que educa o sujeito na sua própria gramática $^{74}$.

específicas. É um processo menos autorregulador (isto é, que conduz ao equilíbrio perfeito) do que autocriador, capaz de se autogerar no tempo. E, se não necessita de poderes reguladores externos, é porque tem sua própria dinâmica. Uma vez instaurado, poderia prosseguir em perfeito movimento perpétuo, autopropulsivo, se não fosse desacelerado ou pervertido por entraves éticos e estatais que constituem atritos nocivos" (Dardot; Laval, 2016, p. 139). Hayek também se posiciona cinicamente em relação ao equilíbrio do mercado nos termos da economia neoclássica. Confira-se Hayek, 1948. p. 37

74 “O empreendedor não é um capitalista ou um produtor nem mesmo o inovador schumpeteriano que muda incessantemente as condições de produção e constitui o motor do crescimento. É um ser 
O sujeito empreendedor educado pelo mercado é munido do aprendizado prático que lhe permite identificar as conveniências e inconveniências no seu itinerário praxeológico para obter, independentemente de qualquer outro fator que além dele e do mercado, a própria satisfação. Qualquer intervenção externa ao processo do mercado é nociva e inútil, portanto. Nociva porque perturbará a alocação natural das experiências e oportunidades que o mercado proporciona, afetando o próprio progresso humano. Inútil porque o sujeito empreendedor prescinde de qualquer ajuda para obter a própria satisfação, desde que o mercado seja deixado às suas próprias condições ${ }^{75}$. Empreender é agir racionalmente, a partir dos saberes oferecidos pelas oportunidades do mercado; o empreendedor tem que ser dotado da expertise necessária às ocasiões, como o caçador à frente do arbusto, esperando o momento em que os coelhos vão sair.

Dessa situação de "suficiência comum" entre o mercado e o empreendedor e a consequente desnecessidade de qualquer intervenção estatal, extrai-se a forma de governabilidade neoliberal dos austríacos: a empresa. O sujeito constituído sobre si mesmo como empresa, ou seja, aquele que calcula, que empreende, que se aventura, que aprende e seleciona saberes e que age no livre mercado constrói a própria sociedade e que se realiza pelo lucro e pelo consumo. $\mathrm{O}$ ambiente de livre concorrência de informações proporciona a matéria prima da qual esse empresário de si mesmo constrói mundos, promove a satisfação de suas necessidades e proclama a desnecessidade de qualquer governo para além de si mesmo e do mercado. Ele se autogoverna. (Dardot; Laval, 2016, p. 143) ${ }^{76}$. Em resumo, o livre mercado é o habitat natural do homo agens. O processo de autoconstrução do mercado e o processo de constituição do sujeito empresário andam de mãos dadas,

dotado de espírito comercial, à procura de qualquer oportunidade de lucro que se apresente e ele possa aproveitar, graças às informações que ele tem e os outros não. Ele se define unicamente por sua intervenção específica na circulação dos bens” (Dardot; Laval, 2016, p. 145)

75 Sobre o mercado como propulsor do progresso humano e do intervencionismo como atraso, confira-se Dardot; Laval, 2016, p. 137: "O processo negativo do Estado cria seres assistidos e o processo do mercado cria seres criativos". Fica evidente a argumentação de von Mises pela Praxeologia e pelo mercado como motores civilizatórios e a redução de toda a História humana à história econômica.

76 É válido reproduzir a afirmação de Thomas Lemke transcrita por Dardot e Laval: "o neoliberalismo apresenta-se como um 'projeto político que tenta criar uma realidade social que supostamente já existe'" (Dardot; Laval, 2016, p. 135) 
se retroalimentam. Proporcionam uma noção de progresso em espiral: sempre circular, sempre para cima.

Nos parágrafos acima explorei aquilo que será primordial para o próximo capítulo: concorrência, empresa, autogoverno. No entanto, antes de encerrar, gostaria de explorar o tema que o "conhecimento" vai desempenhar no mercado. Esse "conhecimento" será objeto de análise pelo último teórico neoliberal que abordo: Friedrich Hayek.

Friedrich August von Hayek ${ }^{77}$ (1899-1992) era de uma família tradicional de intelectuais austríacos, e tal fato foi um dos vários que contribuíram para a sua formação erudita. Hayek não teve a economia como primeiro objeto de estudo. Antes disso debruçou-se sobre questões de Direito, de filosofia e de psicologia, para só depois, sob a supervisão de von Mises, despertar o interesse pelo econômico. O contato prévio com outras matérias ampliou muito os temas aos quais dedicou sua obra, permitindo que fosse mais do que só economista. Durante o colóquio, sua participação foi pequena, mas seu artigo Economics and Knowledge (presente em Hayek, 1948), apresentado em 1935 na London School of Economics mostra que havia notório reconhecimento do seu trabalho antes mesmo do Colóquio Lippmann, ao contrário do que Dardot e Laval levam a crer.

Os interesses que Hayek desperta para o presente trabalho são dois: i) o que é "conhecimento" e qual o papel que ele desempenha no processo mercadológico? ii) como explicar a gênese dos conceitos econômicos sem recorrer ao Direito, conforme Lippmann?

Hayek tem em Mises seu mentor, e em muito concorda com o seu mestre, de modo que ele tomará as perspectivas miseanas de praxeologia, Ação Humana, concorrência imperfeita e os processos de construção mercado-sujeito como bases para seu raciocínio. A inovação de Hayek que interessa ao trabalho quanto à questão do conhecimento está elencada em dois artigos (que Dardot e Laval também

\footnotetext{
${ }^{77}$ Esclarecimento quanto ao nome: o elemento "von" (que deve ser grafado com 'v' minúsculo) é indicador de título nobiliárquico nas antigas monarquias germânicas. Assim, tanto Hayek quanto Mises tinham antepassados na nobreza. Com o fim da monarquia na Áustria em 1919, a família Hayek decidiu abolir o uso do "von" no seu nome, e a partir de então, Hayek passou a assinar "Friedrich A. Hayek", nome pelo qual é mais conhecido.
} 
$\operatorname{citam}^{78}$ ) sobre o uso do conhecimento na sociedade de mercado. De certo modo, Hayek está preocupado em concluir a visão de Mises quanto ao mercado como espaço de propulsão de conhecimento, e não somente como esfera de troca de mercadorias e informações.

O termo que Hayek usa, no original, para se referir a esse "conhecimento" sobre o qual se deseja tratar é knowledge, que compreende algumas traduções para o português além de "conhecimento". O sentido que Hayek lhe impõe é de uma polivalência semântica, pois esse termo não faz referência somente ao conhecimento teórico, especulativo, contemplativo ou acadêmico. Também traduzi-lo como "saber prático" seria insuficiente. O knowledge é todo acúmulo de saberes, sejam teóricos, sejam práticos; em suma: toda informação capaz de ser aprendida a partir do processo do mercado ou capaz de ser utilizada nele. Ou seja, seu conceito é elástico: todo domínio de informação que possa trazer algum proveito ao empreendedor em suas aventuras pelo mercado é knowledge. É o domínio desse "saber específico, voltado para o mercado" que integra a entrepreneurship e alimenta o espírito do empresário de si mesmo. Pode ser uma graduação acadêmica, um talento pessoal, uma habilidade, uma expertise ou qualquer outra coisa, dependendo apenas do contexto em que a Ação Humana se desenvolve no mercado. Por essas razões, vou utilizar o termo no original, pois traduzi-lo o mutilaria o sentido.

A importância do knowledge é fator de desequilíbrio por natureza, e portanto, conforme visto, acirra a gramática de concorrência do mercado, ampliando sua esfera ${ }^{79}$. O equilíbrio, quando existe, corresponde apenas a um estado de não-concorrência entre fatores formadores da agência humana, ou seja: quando esforços empreendidos e custos suportados estejam em relação de equivalência. Surgindo qualquer informação que perturbe o cálculo do empreendedor e afete a agência, o equilíbrio cai por terra ${ }^{80}$.

\footnotetext{
${ }^{78}$ Dardot; Laval, 2016, p. 143

${ }^{79}$ Em Economics and Knowledge, Hayek está preocupado em atacar a concepção de equilíbrio sobre a qual se sustenta a economia neoclássica. $\mathrm{O}$ autor argumenta que o equilíbrio não existe, nem entre ações interindividuais, e nem em status mercadológico, reforçando o papel do knowledge como fator de inovação do mercado a partir do desequilíbrio.

80 "Actions of a person can be said to be in equilibrium in so far as they can be understood as part of one plan. Only if this is the case, only if all these actions have been decided upon at one and the
} 
O uso prático da informação para a identificação das oportunidades de vantagens no processo de mercado põe o empreendedor um passo à frente dos seus concorrentes. Desse modo, o conhecimento que um sujeito julga dominar só é realmente prestativo se for capaz de se transformar em ferramenta no mercado para a obtenção de satisfação ao próprio sujeito. Caso não seja passível de instrumentalização, será supérfluo para aquela ocasião. Versar sobre História da Arte é inútil para um operador da bolsa de valores ao mesmo tempo em que é instrumento de trabalho de um marchand. O saber "História da Arte", portanto, só é mercadologicamente relevante no trato de questões nas quais seu domínio possa trazer ao sujeito uma vantagem sobre os outros na obtenção do resultado buscado. Só nessa condição será considerada knowledge.

O tratamento hayekiano ao knowledge vem para reforçar o argumento já utilizado por Mises para pensar o processo do mercado como fonte do progresso humano. Hayek apresenta uma nova abordagem possível a essa ideia. Conforme explicado, o mercado é composto por uma vastidão de fatores, experiências e informações inumeráveis que são operadas e descobertas pelos sujeitos a partir das suas escolhas e ações. Hayek toma uma perspectiva de ver a situação por um outro lado: se o mercado é uma esfera organizadora de fatores a serem descobertos pelos seus participantes, é possível enxergá-lo também como um ambiente onde se encontram os vários "knowledges" dos empreendedores, de maneira pulverizada e fragmentada. A experiência proporcionada pelo mercado, portanto, é a do encontro entre knowledge e oportunidade de descoberta, movimentando a máquina da sociedade humana.

A esses casamentos entre oportunidade e empreendimento, e as trocas de experiência e aprendizado que daí decorrem, Hayek estabeleceu o seu próprio modelo de sociedade e suas perspectivas de progresso social. $\mathrm{O}$ austríaco identificará que a sociedade humana compreende uma ordem complexa a que denominará "ordem espontânea" ("spontaneous order"), na qual a civilização humana realiza todos os atos e fenômenos sociológicos, políticos e econômicos. Essa ordem é, portanto, a configuração do progresso humano no curso da História.

same moment, and in consideration of the same set of circumstances, have our statements about their interconnections, which we deduce from our assumptions about the knowledge and the preferences of the person, any application" (Hayek, 1948, p. 36) 
A "espontaneidade" da ordem fica submetida a fatores de três categorias distintas, que Hayek, graças à base filosófica de seus primeiros estudos, identifica nas três categorias gregas clássicas de phusei, nomos e taxis os pilares sustentadores dos elementos que formarão a sociedade espontânea. Em apertada síntese ${ }^{81}$, phusei, compreende o universo natural, no qual os elementos, sua existência e seu controle independem da ação e vontade humanas. Nomos e taxis são microcosmos artificiais; nomos é o universo humano da convenção e da deliberação, ou seja: ações que dependem e são dependentes da ação humana para existirem e serem conduzidas. Taxis também é artificial, e portanto depende da ação humana para existir, mas uma vez produzido, sua condução fica autônoma em relação a qualquer tentativa de controle deliberado. Fica fácil entender o porquê do nome "ordem espontânea": ela é composta em parte pelas deliberações humanas no que lhes diz respeito, mas sofre também a influência de fatores incontroláveis, como os naturais ou aqueles que, apesar de artificiais, não podem ser detidos por expressa deliberação.

O mercado será componente da ordem espontânea sob a categoria taxis, evidentemente. O mercado não é categoria natural, mas sua gestão e bom funcionamento não podem ser controlados e não são passíveis de deliberação ${ }^{82}$. Intervir no mercado levará ao seu péssimo desempenho, e gerará efeitos colaterais para toda a sociedade.

O respeito à lógica estruturante da sociedade espontânea é percebido historicamente pela maior integração da sociedade promovida pela combinação saudável das três ordens. Essa combinação é a resposta que as ordens dão aos problemas que cada ordem apresenta às outras duas. Isso permite a construção da

\footnotetext{
${ }^{81}$ As informações para toda essa parte referente à sociedade espontânea hayekiana foram obtidas em Dardot; Laval, 2016, pp. 159 e seguintes. Para evitar fuga de tema, remeto ao capítulo 5 da mencionada obra para explicações mais detalhadas do que são essas categorias gregas e para considerações mais profundas sobre a sociedade espontânea. Procurarei me ater ao objetivo para não divagar sobre fatos que, apesar de interessantes e importantes para uma compreensão mais substancial do pensamento de Hayek, não compreendem o objeto desta dissertação.

${ }^{82}$ Seria possível levantar o seguinte ponto: e se houver uma deliberação no sentido de que se deve intervir no mercado, estabelecendo metas de produção ou uma política compulsória de preços, e os resultados dessas deliberações fossem efetivamente impostos ao mercado? Este deixaria taxis para compor nomos? Hayek argumentaria que tal possibilidade é impossível, pois o que determina a diferença entre taxis e nomos não é a sua origem humana comum, e nem a sua teleologia ("compor a ordem espontânea"), mas antes a sua funcionalidade. Um mercado sob intervenção não irá cumprir sua função de promoção dos "bons encontros" entre agência e oportunidade, e os efeitos disso seriam percebidos nos outros segmentos sociais, espontaneamente. Sobre o desempenho do mercado dentro da categoria de taxis, confira-se Dardot; Laval, 2016, p. 164
} 
"grande sociedade" (ou "sociedade aberta"), da tribo ao Império (Dardot; Laval, 2016, pp. 163-164). A história do progresso humano pode ser resumida nos problemas que surgem e nas tecnologias e saberes produzidos para contorná-los: a agricultura como tecnologia contra a carestia; o liberalismo como tecnologia contra o totalitarismo; o mercado como tecnologia contra o coletivismo e a Ação Humana como tecnologia contra a subserviência humana.

É dessa gestão de tecnologias e saberes que Hayek situará o surgimento de conceitos econômicos, respondendo à segunda questão proposta acima. Os conceitos econômicos são tecnologias produto das necessidades que a própria história econômica apresentou ao homem, e não, portanto, do Direito (conforme argumentava Lippmann). Importa lembrar, contudo, que como a ordem é espontânea, os problemas originados nela são espontâneos também, e muitas vezes as soluções fornecidas para enfrentá-los também são espontâneos. Por espontâneos não se quer dizer "avulsos", mas simplesmente "não-racionais", não "prépensados".

É o que se entende, por exemplo, da leitura de The Fatal Conceit no tocante à propriedade. Hayek identificará a origem da propriedade enquanto instituto não no Direito, nem na economia, mas antes na Moral. (Hayek, 1988, p. 29). Foi a partir da ideia de promessa, de obrigação e de honra que a propriedade passou a ser um instituto de construção da ordem econômica. Utilizando um exemplo criado a partir do livro mencionado: A primeira ideia de propriedade se obtém a partir da operação de troca: ("Troco algo que é meu por algo que é seu!"). A troca, generalizada e desenvolvida partir da introdução do fator moeda, originará o comércio. Enquanto o comércio marítimo mediterrâneo da época clássica se desenvolvia livremente, era preciso o estabelecimento de uma rede de comunicação e de segurança para as relações comerciais que se travavam além-mar. Novos problemas: como garantir que a mercadoria comprada em Tiro chegará a Atenas? Evidentemente há os riscos incontroláveis: naufrágio, pirataria, roubo. Mas quanto à operação comercial em si: como garantir que as partes contratantes cumprirão sua promessa de compra e venda? O primeiro garantidor do cumprimento será a moral, consubstanciada no Pacta sunt servanda. Inadimplida a obrigação, o débito deverá ser solvido a partir do patrimônio do inadimplente, por paralelismo à relação comercial. 
Com esse simples exemplo, a partir de Hayek, se identificou a formação de três tecnologias a partir do problema que elas procuraram resolver: a propriedade a partir da ideia de troca (o "meu pelo seu"), e o posterior desenvolvimento do comércio a distância, que foi salvaguardado pela figura moral da promessa. Esta, por sua vez, encontrou seu lastro na responsabilidade pecuniária do inadimplente, a partir de uma outra ideia de propriedade: propriedade enquanto patrimônio, e patrimônio enquanto última garantia do cumprimento de promessas avençadas. (Hayek, 1988, p. 35)

No exemplo destacado, os problemas surgidos espontaneamente a partir das necessidades propostas pela experiência foram contornados, também espontaneamente, por tecnologias que buscaram solucioná-los. O desenvolvimento dessas tecnologias permitiu a abertura de uma gama de novas experiências possíveis (no caso, o comércio a distância), porém desafiadoras, cujos inconvenientes foram contornados por outra tecnologia (a ideia de responsabilidade patrimonial), e assim por diante.

Quando Hayek identificou na Moral a fonte do instituto da propriedade para fins de comércio, ele estava mais preocupado em afirmar que a propriedade se afirmou de forma espontânea na ordem social (e não sob a forma de construção jurídica). Seu ponto foi demonstrar que a ordem espontânea, pela conjugação das suas três categorias, consegue solucionar os problemas que ela mesma se apresenta. Tais soluções não dependem necessariamente de partirem do campo das deliberações de nomos, como o Direito, apesar de não ser proibido e nem impossível que as soluções brotem de decisões políticas, conforme o caso, especialmente em estágios de maior confluência de fatores ${ }^{83}$.

Desse modo, o supramencionado knowledge é apenas uma partícula tecnológica de auxílio às manifestações espontâneas do mercado, evidenciadas pelas suas oportunidades de descoberta, e que toma parte num processo muito maior no pensamento hayekiano. A obra dos austroamericanos não se resume a uma

\footnotetext{
83 "This emphasis on the spontaneous nature of the extended or macro-order could mislead if it conveyed the impression that, in the macro-order, deliberate organisation [sic] is never important." (Hayek, 1988, p. 37)
} 
apologia do laissez-faire ou do liberalismo. Ela é um projeto para a totalidade das coisas humanas. Uma nova razão de mundo.

\section{4}

\section{Síntese conclusiva}

Neste capítulo, conforme informado desde o início, procurei apresentar essa nova maneira de se estudar o neoliberalismo para além das suas "interpretações convencionais". Não se trata de um novo liberalismo e nem de um modelo restrito a uma interpretação econômica das políticas sociais. Busquei tratá-lo como um projeto de nova sociedade que parte do homem (e não do capitalismo) como peçachave para a construção de um novo mundo. Esse projeto não é uniforme e nem suas vozes ecoam em uníssono. Por trás das discussões travadas em 1938 em Paris há muita discrepância sobre qual o caminho a se seguir e quais os papéis do Estado, do homem e do liberalismo clássico na configuração desse novo mundo.

$\mathrm{Na}$ análise, busquei mostrar essas diferenças de projeto, mas sempre tendo em mente que meu objetivo principal no capítulo era Ludwig von Mises e Friedrich Hayek. Passei, portanto, do "menos austríaco possível" (se é que pode-se expressar assim), com os ordoliberais, para mostrar um Lippmann meio original, com algo que antecipará Mises e Hayek até chegar a esses dois e seus grandes conceitos: ordem concorrencial, empreendedorismo e empresa como formas de governo do sujeito por si mesmo, instrumentalização dos saberes, autorrealização de si pelo lucro e pelo consumo e essa grande máquina chamada mercado, que promete ao homem empreendedor todas as delícias do mundo. A exaltação do mercado como joia da coroa do progresso humano pelos austríacos, em especial pelo "ex socialista" Hayek, poderia, de alguma forma, ser uma subversão cínica da frase de Santo Agostinho:

"Tarde te amei, ò beleza sempre antiga e sempre nova!" 


\title{
"Vinde a nós o Vosso reino": O governo do homem iurdiano.
}

\author{
"Where there is discord. May we bring harmony. \\ Where there is error, may we bring Truth. Where \\ there is doubt, may we bring Faith, and where there \\ is dispair, may we bring hope!" \\ - Margareth Thatcher, citando a oração de São \\ Francisco de Assis na sua chegada a Downing Street
} (04 de maio de 1979)

Expostas as considerações sobre o neopentecostalismo e o neoliberalismo nos capítulos anteriores, procurei destacá-los como experiências dentro do cristianismo ou do liberalismo, ressaltando suas características e modelos de sujeitos passíveis de serem chamados de "fiel da IURD" e "empresário de si mesmo". Se o primeiro e segundo capítulos tiveram uma perspectiva histórica, procurarei desenvolver neste, com uma abordagem mais filosófica, aquilo que gostaria de chamar de o homem iurdiano, ou seja, o sujeito produto do encontro das duas experiências, a partir da análise dos conceitos de biopolítica (e biopoder), norma e como esses elementos, conectados a outros conceitos previamente apresentados, contribuem para uma "fábrica" do homem iurdiano.

\section{1}

\section{Governamentalidade e Biopolítica.}

Existe certa curiosidade com o Nascimento da Biopolítica, de Michel Foucault. Sendo o curso-livro conhecido pela interpretação foucaultiana do liberalismo e do neoliberalismo, por que se chama nascimento da biopolítica? O que é biopolítica e qual sua relação com o neoliberal? 
Tratar de conceitos foucaultianos envolve um desafio em si mesmo, pois o pensamento de Foucault é marcado muitas vezes pela crítica aos conceitos em si, pelo menos enquanto definições de objetos. O autor não pretendia se apresentar, em seus trabalhos, como filósofo, formulador de conceitos e construtor de definições. Antes preferia ser um "mercador de instrumentos" ${ }^{\prime 4}$. Desse modo, as noções que emergem do pensamento foucaultiano, como sujeito, poder, governamentalidade (gouvernementalité) e biopolítica, são nomes que se aplicam a análises, e não a objetos; são ferramentas, e não cânones. A governamentalidade pode ser a forma de condução dos sujeitos à realização de um determinado fim, como pode ser a relação entre o sujeito e seu meio ${ }^{85}$. Da mesma forma a biopolítica pode ser tecnologia de gestão de populações nos aspectos concernentes a toda matéria da vida: nascimento, doenças, higiene, passando também por sexualidade, riqueza, pobreza, carestia, etc. (Laval, 2018, p. 30). A combinação da governamentalidade com a biopolítica - ou a biopolítica como governo - estabelecendo relações de poder, estimulando condutas e alocando sujeitos é um dos objetivos que Foucault deseja estabelecer como bússola na sua análise do neoliberalismo; ou seja, descobrir como a governança neoliberal se utiliza dessa ferramenta de incentivo a determinadas condutas visando determinados resultados ${ }^{86}$.

\footnotetext{
${ }^{84}$ Conforme a entrevista a Dardot e Laval leva a crer, sob a postura de Foucault e os intelectuais (Dardot; Laval, 2015), e o próprio Foucault, ao falar do seu próprio eu enquanto intelectual, preferia se descrever como alguém que fornece "instrumentos" para se abordar determinados assuntos, investigar certos conceitos ou criticar pensamentos (Nisso confira-se Laval, 2018, p. 26). Também na primeira aula de Sécurité, Territoire, Population, que precede Naissance de la Biopolitique, Foucault aborda essa concepção de "troca de instrumentos", que é marcante do seu pensamento.
}

85 "Par ce mot de "gouvernementalité», je veux dire trois choses: Par "gouvernementalité»,j'entends l'ensemble constitué par les institutions, les procédures, analyses et réflexions, les calculs et les tactiques qui permettent d' exercer cette forme bien spécifique, quoique très complexe, de pouvoir qui a pour cible principale la population, pour forme majeure de savoir 1 'économie politique, pour instrument technique essentiel les dispositifs de sécurité. Deuxièmement, par " gouvernementalité ", j'entends la tendance, la ligne de force qui, dans tout l'Occident, n'a pas cessé de conduire, et depuis fort longtemps, vers la prééminence de ce type de pouvoir qu'on peut appeler le " gouvernement " sur tous les autres : souveraineté, discipline, et qui a amené, d'une part, le développement de toute une série d'appareils spécifiques de gouvernement [et, d'autre part]* le développement de toute une série de savoirs. Enfin, par " gouvernementalité »,je crois qu'il faudrait entendre le processus, ou plutôt le résultat du processus par lequel! 'État de justice du Moyen Âge,

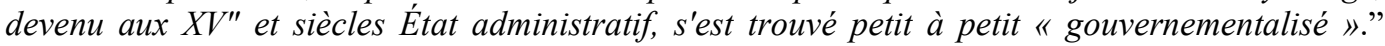
(Foucault, 2004, p. 111)

\footnotetext{
${ }^{86}$ Quanto ao destinatário do poder, Judith Revel diferencia entre a disciplina, que cuida da conduta individual de cada sujeito, e controle, este, destinado às populações:

"en tanto que la disciplina parecía interesarse sólo en los individuos, el control se interesa precisamente en las «poblaciones», es decir, en nuevos objetos a los que de alli en más se aplican las relaciones de poder. Las «poblaciones» son, en realidad, grupos homogéneos conformados por
} 
Em seu curso sobre o nascimento da biopolítica, Foucault procura entender como, e por quais mecanismos, se operou a passagem de uma governamentalidade do Estado de polícia para aquela do Estado liberal. Como meu foco é a biopolítica junto ao neoliberalismo, vou me escusar de explicar detalhadamente como se deu essa passagem, reportando-me a ela somente na medida do necessário. Para a explicação completa dessa transformação, remeto às três primeiras aulas do curso (Foucault, 2008) ${ }^{87}$.

A questão que o liberalismo propõe - e que o neoliberalismo posteriormente também levará em conta - é a questão da limitação do poder e da condução do governo. "Quais são os limites da ação governamental? Quais as maneiras de se governar, de maneira que se governe melhor, mas com menos perturbação à ordem das coisas?". Toda questão de governamentalidade terá que levar em conta, naturalmente, a questão do poder. Mas o poder não é um elemento no pensamento foucaultiano. Ele não é um centro de gravitação da governamentalidade ou uma fonte de onde escorre o governo. A governamentalidade é composta por relações de poder, com várias esferas de incidência: o poder familiar sobre as crianças; o poder psiquiátrico sobre os loucos; o poder corretivo sobre os detentos e etc., e não sobre um núcleo elementar chamado "poder", de modo que os comumente chamados poderes de império do Estado são apenas uma das formas de poder imersas no caleidoscópio de relações de poder constituintes da racionalidade governamental $^{88}$. Assim, falar em limitação de poder, no bojo do liberalismo envolve falar da limitação, por outros poderes, do poder interventivo do Estado, promovendo uma nova configuração de governo.

el poder sobre la base de un fundamento presuntamente natural, que permite definir su consistencia identitaria, o sea, cierto número de rasgos naturales comunes que los caracterizarían" (Revel, 2014, p. 152) Ou seja, as populações são objeto de uma determinada forma de poder (o controle), e são definidas por um fundamento que as agremia em bases consideradas naturais.

${ }^{87}$ Para entender melhor o que Foucault entendia por "razão de Estado", "Estado de polícia", "liberalismo" e outros conceitos fundamentais à análise histórica do neoliberalismo segundo Foucault, a obra de Bidet (2016) me foi muito útil, de modo que remeto à leitura das páginas $42 \mathrm{e}$ seguintes da obra em referência para expansão do entendimento.

88 "O próprio termo 'poder' não faz mais do que designar um campo de relações que tem que ser analisado por inteiro, e o que propus chamar de governamentalidade, isto é, a maneira como se conduz a conduta dos homens, não é mais do que uma proposta de grade de análise para essas relações de poder" (Foucault, 2008, p. 258) 
No liberalismo, os discursos de limitação do poder praticado pelo Estado emergirão de dois ambientes principais. De um lado, o direito, o discurso jurídico, assentado sobre as doutrinas do direito natural, do constitucionalismo e da contenção do poder do soberano posto que submetido a um juízo maior (a Deus, à natureza, à razão, à nação, etc). Do outro lado, a economia política, o discurso econômico, que surge a partir de uma visão gerencial da sociedade como um grande depósito de vida: vidas humanas, animais e plantas, recursos naturais (e capazes de gerar mais vida, portanto $)^{89}$. Desse modo, o liberalismo, enquanto racionalidade política, pode ser inscrito na pergunta: "como maximizar o governo, reduzindo ao mínimo os custos, os gastos e os desgastes com esse governo? Como governar mais com menos?". Ao deslocar-se do parâmetro de mensuração do "bom governo" do Estado para a população, desloca-se também a racionalidade governamental do direito natural para a economia política, não se tratando mais de cuidar do crescimento do Estado, ou da sua maximização, mas da condução e governança do conjunto de indivíduos socialmente distribuídos na população.

\begin{abstract}
Ora, por 'economia política' entende-se também, de forma mais ampla e mais prática, todo método de governo capaz de assegurar a prosperidade de uma nação. E, finalmente [a] economia política - por sinal é o termo que vocês veem utilizado por Rousseau em seu célebre verbete 'Economia política' da Enciclopédia - a economia política é uma espécie de reflexão geral sobre a organização, a distribuição e a limitação dos poderes numa sociedade. A economia política, ao meu ver, é fundamentalmente o que possibilitou assegurar a autolimitação da razão governamental. (Foucault, 2008, p. 19) Colchetes e itálicos no original. Negritos meus
\end{abstract}

A primeira compreensão da economia política como fato constitutivo da biopolítica advém da conjugação desses dois aspectos: método governamental de assegurar a prosperidade nacional; reflexão sobre a organização da disposição de poderes, ambos permitem identificar na economia política uma reflexão não sobre o Estado, a soberania ou a política, mas sobre o próprio governo. Tomando a população como matéria de ação da governamentalidade, deve-se construir um método de relação de poderes atuantes sobre o corpo social para que este seja conduzido aos objetivos do Estado: o bem-estar da sociedade por meio do seu

\footnotetext{
${ }^{89}$ Para referencial histórico, o surgimento do liberalismo e sua solidificação enquanto racionalidade política se dá entre os séculos XVIII e XIX, no mesmo período em que a revolução industrial anuncia uma nova fase do capitalismo na Europa. É compreensível por que a economia política passa a ser um fator importante para a nova arte de governar.
} 
enriquecimento. O problema da simples limitação de poder não é mais suficiente, portanto, se a questão deixa de ser "até onde o governo pode agir" para ser "como o governo deve agir sobre essa matéria (a população) para atingir determinados fins adequados".

Os limites jurídicos à ação do Estado diferem da racionalidade da economia política também em sua gênese. O direito natural é gestado fora do campo do governo, enquanto a economia política nasceu e se expandiu dentro da racionalidade governamental do Estado, de modo que, diferentemente do direito natural, não é objeção imposta, a posteriori, ao Estado como forma de convalidar a condução do governo (Foucault, 2008, p. 20). Antes, a economia política se confunde com os próprios objetivos do governo de gerir a população ao tempo em que almeja a prosperidade, de maneira que economia política e governamentalidade liberal não se excluem. São complementares um do outro.

Dessa sorte, se o direito natural faz objeções ao governo, pedindo-o que "governe menos" e respeite limites, a economia política substancia esse governo, procurando a maximização da sua ação e reduzindo todos os estanques à sua atuação, pois governar "econômico-politicamente" é governar pelos melhores interesses do Estado e da população. Este é o novo norte da ação de condução dos corpos: produção e gestão de riqueza. A esse governo total, Foucault chamou de despotismo ${ }^{90}$. Por isso é possível afirmar que "a biopolítica parece assinalar a superação da tradicional dicotomia Estado/sociedade em benefício de uma economia política da vida como um todo"91

Essa concepção despótica é consequência de uma acepção do mercado como espaço de formação da verdade, o que envolve tomá-lo como o mecanismo que servirá de bússola para a condução biopolítica da população. A economia política,

\footnotetext{
90 "A primeira consequência política da primeira reflexão econômica que houve na história do pensamento europeu, pois bem, [é] precisamente uma consequência que vai totalmente de encontro ao que quiseram os juristas. é uma consequência que conclui pela necessidade de um despotismo total. A primeira economia política é, bem entendi, a dos fisiocratas, e vocês sabem que os fisiocratas (tornarei sobre isso posteriormente) concluíram, a partir da sua análise econômica, que o poder político devia ser um poder sem limitação externa, sem contrapeso externo, sem fronteira vinda de outra coisa que não ele próprio, e é isso que eles chamam de despotismo. O despotismo é um governo econômico, mas que não é encerrado, que não é desenhado em suas fronteiras por nada além de uma economia que ele próprio definiu e ele próprio controla totalmente" (Foucault, 2008, p. 20)
}

${ }^{91}$ Conforme Revel, 2014, p. 165 
gerida dentro da razão governamental, não tem por escopo a condução do mercado, ou a formação da verdade econômica, mas sim o estudo das verdades proporcionadas a partir do fenômeno mercadológico. O mercado não é conduzido: ele conduz (Foucault, 2008, p. 42). A sua palavra é o preço como denominador comum entre oferta e demanda, custo e produção, necessidade de venda e necessidade de compra.

\begin{abstract}
O mercado é que vai fazer que o bom governo não seja somente um governo justo. $\mathrm{O}$ mercado é que vai fazer que o governo, agora, para poder ser um bom governo, funcione com base na verdade. Portanto, em toda essa história e na formação de uma nova arte de governar, a economia política não deve seu papel privilegiado ao fato de que ditaria ao governo um bom tipo de conduta
\end{abstract}

\title{
$[\ldots]$
}

O mercado deve dizer a verdade, deve dizer a verdade em relação à prática governamental. Seu papel de veridição é que vai, doravante, e de uma forma simplesmente secundária, comandar, ditar, prescrever os mecanismos jurisdicionais ou a ausência de mecanismos jurisdicionais sobre os quais deverá se articular. (Foucault, 2008, p. 45) ${ }^{92}$

Assim, o compasso da ação do bom governo deixa de ser o respeito a princípios jurídicos exteriores à racionalidade governamental - até então condição para o governo legítimo - para tornar-se o respeito a determinado espaço "natural" de formação da verdade, cujo desconhecimento ou descumprimento por parte do governo não o constituirá em ilegítimo, mas sim em ignorante ${ }^{93}$. O Estado deixa de ser um fim em si mesmo para tornar-se um meio para o enriquecimento generalizado da população

Essa mudança operada na racionalidade governamental explicita o porquê de Foucault ter tomado a economia política como instrumento técnico essencial aos dispositivos de segurança, bem como a população como forma de saber. (Foucault, 2004, p. 111). Também evidencia um novo aspecto do poder: ele não está restrito a um caráter coercitivo, podendo ser também produtivo. O biopoder, aliás, é

\footnotetext{
${ }^{92} \mathrm{Na}$ mesma página, o trecho suprimido trata da relação entre a economia política e a formação do mercado como lugar de veridição:

"A economia política foi importante, inclusive em sua formulação teórica, na medida em que (somente na medida, mas é uma medida evidentemente considerável) indicou onde o governo devia ir buscar o princípio de verdade da sua própria prática governamental. Digamos em termos simples e bárbaros que o mercado, de lugar de jurisdição que era até o início do século XVIII, está se tornando, pro meio de todas essas técnicas que, por sinal, evoquei ano passado a propósito da escassez alimentar, dos mercados de cereais, etc., um lugar que chamarei de lugar de veridição"
}

${ }^{93}$ Conforme Foucault, 2008, p. 23 
produtivo por sua essência e seu objeto: deve gerir vidas, e gerir a vida envolve também produzi-la ${ }^{94}$. "La biopolitique elle aussi est productive. Ce qu'elle produit, c'est la «vie»" (Laval, 2018, p. 73). Trata-se de dirigir os indivíduos a partir da situação em que se encontram (no caso neoliberal: a concorrência mercadológica), mas não como poder repressivo ou vigilante apenas, restrito a uma esfera de dominação. O biopoder tem sua particularidade por se exercer "no plano da vida", e não "sobre a vida":

A propósito desse biopoder, Foucault escreveu que tal é um poder que «se situa e se exerce ao nível da vida » : não sobre a vida, mas « ao nível da vida », à existência daqueles aos quais ele é imanente. Sob tal perspectiva, o poder não mais é definido como uma técnica de dominação : ele abandona seu caráter subjugador e se transforma no « ato de estruturar o campo de ação eventual dos outros ", esta é a definição que Foucault propõe de governamentalidade (Macherey, 2014, p. 36) ${ }^{95}$

A questão da governamentalidade biopolítica consistirá, portanto, nessas novidades apresentadas pelo século XVIII: uma nova matéria política (a população), uma nova racionalidade governamental (a economia política) e um novo espaço formação da verdade quanto àquilo que deve ser a conduta governamental (o mercado) ${ }^{96}$.

\footnotetext{
${ }^{94}$ Acerca do questionamento do poder como "somente coercitivo" é válido conferir duas entrevistas. Uma pelo próprio Foucault, realizada em 07 de maio de 1981 na Universidade Católica de Louvain (encontrada em https://www.youtube.com/watch? $\mathrm{v}=132 \mathrm{QZ} \_\mathrm{C} 3 \mathrm{ovs} \& \mathrm{t}=942 \mathrm{~s}$ ), na qual algumas considerações sobre o poder e o governo são feitas (a partir de 15:50), e também a entrevista que Christian Laval concedeu em 28 de fevereiro de 2018 (encontrada em https://www.youtube.com/watch? $v=T I p Q v y d A E s 4 \& t=1414 \mathrm{~s}$ ), sobre a possibilidade de transformação do poder sob o neoliberalismo, que passa de um aspecto repressivo-coercitivo disciplinar para abordar uma perspectiva de estímulo ao sujeito neoliberal a realizar a conduta que se espera dele. Laval apresenta Foucault como um intérprete do neoliberalismo que contesta a ideia de que o poder só opera por meio da contenção, mas desempenhando também o papel de estímulo.

\begin{abstract}
${ }^{95}$ Tradução minha. No original:
À propôs de ce biopouvoir, Foucault écrit qu'il est um pouvoir qui «se situe et s'exerce au niveau de la vie»: non sur la vie, donc, mais «au niveau de la vie», à l'existence de laquelle il s'est rendu imanente. Dans une telle perspective, le pouvoir ne se définit plus comme une technique de domination: ayant abandonné son caractere surplombant, il est devenu «l'acte de structurer le champ d'action éventuel des autres», ce qui est la définition que Foucault propose de la gouvernementalité.
\end{abstract}

\footnotetext{
${ }^{96}$ A governamentalidade neoliberal, cumpre observar, não é um elemento que exclui os mecanismos desenvolvidos pelas governamentalidades que a precederam. Ela possui mecanismos de vigilância, de disciplina, que convivem junto aos mecanismos novos - biopolíticos - amalgamando uma nova relação de poder e um novo. As experiências acumulam-se, e não necessariamente se excluem. Esse era um fato já identificado por Foucault no curso do ano precedente (Foucault, 2004, p. 11)
} 
Em uma passagem bem explicativa, conectando biopolítica e

liberalismo, escreve Judith Revel:

\begin{abstract}
O termo "biopolítica" designa, então, a maneira pela qual o poder tem de transformar, entre o fím do século XVIII e começo do século XIX, como objeto de governo não só os indivíduos, através de certos procedimentos disciplinadores, mas também ao conjunto de seres humanos reunidos em coletivos. A biopolítica - como condução de biopoderes locais - se ocupa, pois, da gestão de saúde, de higiene, de alimentação, de sexualidade, etc., na medida em que estas passaram a ser metas políticas. Como sucede ao conceito de disciplina ao qual se associa, a noção de biopolítica implica uma análise histórica do marco da racionalidade política em que aparece, vale dizer, o nascimento do liberalismo.

Na realidade, Foucault entende por "liberalismo" dois fatos que coincidem somente em parte. Por um lado, uma transformação econômica que modifica profundamente a produção e que está essencialmente vinculada à primeira industrialização; por outro, o surgimento de uma forma de governo que não somente tende a maximizar seus efeitos reduzindo seus custos, conforme o modelo da produção industrial, mas que também afirma o risco permanente de se governar demais. (Revel, 2014, pp. 163-164) ${ }^{97}$
\end{abstract}

Nas páginas precedentes, já foi explicado como essa identificação do mercado como mecanismo formador de verdade foi tratado pelos neoliberais austríacos, de maneira que o sujeito empreendedor deve obter na esfera mercadológica o "oráculo" que guiará a sua conduta no tocante à Ação Humana, bem como também encontrará no mercado as "ferramentas" que utilizará na sua aventura empreendedora (especialmente nas temáticas do knowledge hayekiano e na perspectiva do mercado como processo de descoberta). O processo biopolítico de condução dos sujeitos por meio do estímulo de condutas, visando determinados resultados, ganhará forma no mercado enquanto formador da verdade biopolítica (Foucault) e horizonte da ação antropológica do homo agens. Também procurei

\footnotetext{
${ }^{97}$ Tradução minha. No original:

El término «biopolítica» designa, entonces, la manera en que el poder tiene a transformarse, entre fines del siglo XVIII y comienzos del siglo XIX, con el objeto de gobernar no sólo a los individuos, a través de cierto número de procedimientos disciplinarios, sino también al conjunto de los seres humanos reunidos en poblaciones. La biopolítica - por conducto de los biopoderes locales - se ocupa, pues, de la gestión de la salud, la higiene, la alimentación, la sexualidad, la natalidad, etc., en la medida en que estas han pasado a ser metas políticas. Como sucede con el concepto de disciplina al que está asociada, la noción de biopolítica implica un análisis histórico del marco de la racionalidad política en el que aparece, vale decir, el nacimiento del liberalismo.
}

En realidad, Foucault entiende por «liberalismo» dos hechos que coinciden sólo en parte por un lado, una transformación económica que modifica profundamente la producción y está esencialmente vinculada a la primera industrialización; por el otro, el surgimiento de un ejercicio del gobierno que no sólo tiende a maximizar sus efectos reduciendo sus costos, según el modelo de la producción industrial, sino que afirma también el riesgo permanente de excederse en el gobierno 
afirmar o sujeito neoliberal como fruto do papel pedagógico do mercado, e pautado por duas formas de governo de si mesmo: a empresa e a concorrência.

Falar de uma racionalidade biopolítica, ou de uma governamentalidade empresarial-concorrencial, no entanto, não é evidente, e pressupõe uma forma de sujeito que se autoimpõe uma marca de governo definida pela verdade neoliberal, a saber: de que a concorrência é a gramática da vida, a empresa é a gramática do sujeito e o mercado é a gramática da verdade. Ou como Dardot e Laval: “'Empresa' é também o nome que se deve dar ao governo de si na era neoliberal. O que quer dizer que esse 'governo de si empresarial' é diferente e muito mais do que a ‘cultura de empresa"' (Dardot, Laval, 2016, p. 328). Em miúdos: já tendo explicado o que é esse sujeito empresário, cumpre explicar como ele se forma.

\section{2}

\section{As verdades e as normas.}

Um discurso sobre a mutação do homem, a construção de uma subjetividade ou a "modelação das almas", como Margareth Thatcher gostaria de falar, envolve produzir, no sujeito, a mudança almejada, como condição para se construir uma razão de mundo. Todo o discurso do mercado como espaço construtor da verdade é incompleto se essa verdade não é incorporada nos "corações e mentes" dos sujeitos sob os quais o biopoder procura agir. É preciso fabricar esse sujeito empresário e concorrente.

Novamente nesse sentido as análises desenvolvidas por Dardot e Laval serão de ajuda, partindo de algumas metáforas que podem ser extraídas da sua obra conjunta.

Conforme já explicitado, a perspectiva foucaultiana deste trabalho parte da análise da construção de subjetividades por meio de normas de conduta para analisar o neoliberalismo como uma teia de relações de poder que controlam não só o mercado ou a força de trabalho, mas sim a própria vida do sujeito inscrito nessa teia, de modo que ele não será operador (e nem operado) do mecanismo neoliberal. Antes, buscará ser parte integrante desse grande mecanismo.

Ao tomar o neoliberalismo sob tal perspectiva, procura-se evitar tratá-lo como um novo espírito do capitalismo, conforme a análise de Luc Boltanski e Ève 
Chiapello, segundo a qual o capitalismo precisa "inventar" um aparato ideológico potente para "convencer" e "justificar" os sujeitos produtores a constituir-se em mão de obra de modo que o capital sobreviva. Tem-se aqui, como Dardot e Laval bem lembram, uma variação da metáfora do "grande relojoeiro"; (i.e. aquele que, sozinho, tem acesso ao relógio, regulando o mecanismo e o tempo) (Dardot; Laval, 2016, p. 327), que, na terceira fase espiritual, estética, do capitalismo em que nos encontramos, mergulha o trabalhador contemporâneo numa configuração hedonista, criativa, independente, para engajar-se na realidade do capital e participar do compasso imposto pelo relojoeiro.

A perspectiva de Dardot e Laval, a partir de Foucault, pode parecer ratificar o modelo do grande relojoeiro num primeiro momento de análise. A sutileza que a realça em relação à ideia de um espírito do capitalismo reside, todavia, no foco que se emprega no processo de construção do sujeito neoliberal como condição para qualificação do neoliberalismo não como parte contida no capitalismo, mas como razão de mundo. Dito de outro modo, o importante não é o relojoeiro, mas o relógio ${ }^{98}$.

A capacidade de afirmação do neoliberalismo depende da transferência, ao sujeito empresário, dos riscos e adversidades inerentes à aventura mercadológica, e da consequente aceitação dessa transferência pelo sujeito. O empresário, conforme explicado no capítulo 2, é um indivíduo que enxerga no mercado e na Ação Humana a possibilidade de obtenção de um grau de satisfação maior para si, mas que sabe que sua agência não ecoa solitária pelo mercado. Antes, é reverberada por outros sujeitos, que reagem a ela, não necessariamente desfavorável ao primeiro indivíduo. Esse sujeito aprende, portanto, que colaborar com outros pode significar ajudar a si mesmo: "O que é bom para o outro, é bom para mim" e, nesse itinerário de procurar a maior satisfação e evitar as amarguras, esse sujeito empresário entrega-se por completo à aventura empresarial e passa a governa-se "pelos prazeres e pelas dores" (Dardot; Laval, 2016, p. 325). O sujeito neoliberal é uma engrenagem afetiva no mecanismo do relógio. Daqui já se podem extrair duas considerações: i) o

\footnotetext{
${ }^{98}$ Refriso que este trabalho não tem por objetivo desafiar, desqualificar ou de qualquer forma desmerecer outras análises do neoliberalismo. A menção que faço aqui ao trabalho de Boltanski e Chiapello visa apenas delimitar melhor a particularidade do pensamento de Dardot e Laval em relação ao argumento daqueles outros autores.
} 
mecanismo, entendido aqui como a estrutura neoliberal, não basta a si mesmo: é necessário criar a peça que o irá compor, de maneira que o mecanismo não é um objeto a ser operado unilateralmente pelo relojoeiro, mas sim ter seu funcionamento "automático" em razão do encaixe das peças do relógio, fazendo com que o neoliberalismo enquanto razão de mundo trabalhe a partir do contato das peças, umas com as outras; ii) Essa construção do sujeito neoliberal (e do homem iurdiano, consequentemente) é uma também uma construção afetiva. A perspectiva de um sujeito governado pelos prazeres e pelas dores é de grande importância para o raciocínio. Essa necessidade e capacidade do sujeito de assumir essa figura governativa da empresa para si é o que destaca a análise de Dardot e Laval das outras perspectivas sobre o neoliberalismo.

Sendo a perspectiva subjetiva essencial à construção da nova razão do mundo, por meio da assunção da forma empresarial pelo indivíduo, deve-se explicar como os mecanismos de poder biopolítico promovem essa transformação nos corações e almas dos sujeitos.

A biopolítica, conforme visto, é uma racionalidade governamental apta a gerir uma população tomando como ferramenta o biopoder, ou seja, a própria vida enquanto matéria sobre a qual o poder atua, e buscando a condução dos indivíduos daquele agrupamento a determinados objetivos, tidos como os verdadeiros fins para os quais o governo é instituído. Também em algumas notas acima, expus, a questão do biopoder enquanto controle, ou seja, não um poder disciplinar individualizado a um sujeito em particular, mas como uma norma de conduta dos coletivos de sujeitos. Reforço agora, o papel que esta norma tem na produção do sujeito biopolítico.

A norma age sobre as populações para produzir a "vigilância desindividualizada" necessária ao cumprimento das condutas prescritas pela "verdade oculta" por trás do mecanismo sobre o qual a biopolítica se ergue ${ }^{99}$. A figura da norma, presente em vários momentos do pensamento foucaultiano, surge como o instrumento de molde da população e do indivíduo (como mecanismo de

\footnotetext{
99 "La norma corresponde, pues, a la aparición de un biopoder, es decir, de un poder sobre la vida, así como de las formas de gubernamentalidad a esta ligadas" (Revel. 2014, p. 154)
} 
controle e de disciplina), para estabelecer a conduta que os sujeitos devem tomar (Revel, 2014, 153).

Desse modo, em um primeiro momento para a formação do sujeito, é necessária uma estrutura de poderes destinados à disciplina e ao controle para que, de um lado, constituam o espaço "população", para que o indivíduo sob construção seja introduzido nela; e de outro, a mobilização de um aparato para controle individualizado sobre cada indivíduo, capaz de incuti-lo a autodisciplina empresarial e a educação fundamental a uma sociedade que tem a concorrência como forma social. O aparato normativo é, dessa maneira, vigilante e constitutivo do sujeito.

\begin{abstract}
O poder passa por um controle social cujo relevo não é somente a justiça, mas sim uma ampla série de outros poderes laterais (as instituições psicológicas, psiquiátricas, criminológicas, médicas, pedagógicas, de controle dos corpos e a implementação de uma política de saúde, os mecanismos de assistência, as organizações filantrópicas e os patrocínios, etc.) que se articulam em dois tempos: como vimos, se trata, por um lado, de constituir populações nas quais se possa inserir nos indivíduos (o controle é, essencialmente, uma economia de poder que administra a sociedade em função de modelos normativos globais, integrados em um aparato de Estado centralizado); mas se trata também, por outro lado, de que o poder se faça capilar, quer dizer, de instalar um sistema de individualização dedicado a modelar cada indivíduo e administrar sua existência. (Revel, 2014, p. $155-156)^{100}$
\end{abstract}

Dessa passagem destacada, observa-se que Judith Revel faz menção ao controle como "economia de poder", referenciando um dos sentidos da expressão "economia política" que Michel Foucault empregou em Nascimento da Biopolítica: a disposição de poderes na sociedade, que será uma das ferramentas biopolíticas do liberalismo (e do neoliberalismo). Também foram elencados diversos saberes, como a psicologia e a pedagogia, como dispositivos de molde do sujeito e do ambiente onde vive. Esses saberes serão a pedra angular por meio do qual a norma

\footnotetext{
${ }^{100}$ Tradução mina. No original:

El poder pasa por un control social cuyo relevo no es solamente la justicia, sino una amplia serie de otros poderes laterales (las instituciones psicológicas, psiquiátricas, criminológicas, médicas, pedagógicas; la gestión de los cuerpos y la implementación de una política de salud; los mecanismos de asistencia, las organizaciones filantrópicas y los patrocicios, etc.) que se articulan en dos tiempos: como hemos visto, se trata, por un lado, de constituir poblaciones en las cuales se pueda insertar a los individuos (el control es, esencialmente, una economía del poder que administra a la sociedad en función de modelos normativos globales integrados en un aparato de Estado centralizado); pero se trata también, por el otro, de que el poder se haga capilar, es decir, de instalar un sistema de individualización dedicado a modelar a cada individuo y administrar su existencia.
} 
biopolítica trabalha o indivíduo, pois a primeira operação realizada no sujeito é a sua dessingularização ontológica (Revel), e a posterior unificação existencial em torno da forma empresa (Dardot e Laval).

O primeiro procedimento consiste em "peneirar" no sujeito todos os traços afetivos, psicológicos e que distinguem ontologicamente os indivíduos uns dos outros. É a operação de pegar o grande mosaico populacional e homogeneizá-lo para atribuir ao caldo amorfo, afetivo e multitudinário dos sujeitos uma disciplina e a forma de uma série, isto é, uma organização artificial dos sujeitos para a liberação de mão de obra e utilidade produtiva ${ }^{101}$.

Feita essa clivagem, os elementos normativos "adestram" o sujeito para transformá-lo no sujeito unitário, ou seja, aquele, após ser "peneirado" da sua singularidade, assume a ética existencial de que ele é responsável pelo próprio destino, ou seja, pelos frutos que colherá, ou pelas amarguras que acumulará. Esse indivíduo é o único responsável pelo próprio sucesso em um ambiente de acirrada concorrência, e portanto cabe a ele se preparar e se construir para sobreviver no despotismo mercadológico:

\begin{abstract}
Trata-se de ver nele [o sujeito neoliberal] o sujeito que deve participar inteiramente, engajar-se plenamente, entregar-se por completo a sua atividade profissional. $\mathrm{O}$ sujeito unitário é o sujeito do envolvimento total de si mesmo. (Dardot; Laval, 2016, p. 327) Colchetes meus
\end{abstract}

É nessa última operação que reside o cerne do governo neoliberal: ao "assumir o seu próprio destino", o sujeito neoliberal atribui os frutos da sua agência são de responsabilidade unicamente sua, sendo dispensável toda a providência estatal. Afinal, é pela busca pela satisfação social que o indivíduo empreende suas ações. O fracasso pelo cálculo mal feito não pode ser perdoado em razão da norma, como forma de separar entre o sujeito bom empreendedor e o servo inútil. O

\footnotetext{
101 "Lo que se trata de comprender aqui es que el análisis de los dispositivos disciplinarios implica para Foucault, a la vez, un aislamiento de los demás, una desingularización obtenida a través de la «corrección» y la «reforma» (puesto que sólo vaciando a cada hombre de su singularidad subjetiva se lo puede rearticular en un "individuo» objetivado y controlado), y la reinserción de este individuo ahora dócil en una "serie» según el principio de la utilidad productiva." (Revel, 2014, p. 159). Mais adiante, na mesma página, diz a autora:

"La serie - que no es otra cosa que la configuración abstracta de la imagen de la cadena de trabajo - exige que los individuos que la componen sean previamente desingularizados para poder luego atribuirles un rango, una posición, una morada."
} 
autogoverno de si, o participar inteiramente do seu eu profissional como norma de conduta da vida e busca incessante pela majoração da eficácia são as ordens do dia.

\begin{abstract}
Com efeito, o novo governo dos sujeitos pressupõe que a empresa não seja uma 'comunidade' ou um lugar de realização pessoal, mas um instrumento e um espaço de competição. Ela é apresentada idealmente, acima de tudo como um lugar de todas as inovações, da mudança permanente, da adaptação contínua às variações da demanda do mercado, da busca de excelência, da falha 'zero'. De modo, injunge-se o sujeito a conformar-se intimamente, por um trabalho interior constante, à seguinte imagem: ele deve cuidar constantemente para ser o mais eficaz possível, mostrar-se inteiramente envolvido no trabalho, aperfeiçoar-se por uma aprendizagem contínua, aceitar a grande flexibilidade exigida pelas mudanças incessantes imposta pelo mercado. Especialista em si mesmo, empregador de si mesmo, inventor de si mesmo, empreendedor de si mesmo: a racionalidade neoliberal impele o eu a agir sobre si mesmo para fortalecer-se e, assim, sobreviver na competição. Todas as atividades devem assemelhar-se a uma produção, a um investimento, a um cálculo de custos. (Dardot; Laval, 2016, pp. 329-330)
\end{abstract}

Dessa maneira, a norma é o elemento que funciona como o indicadorprodutor de subjetividade, e é "emanada" a partir da verdade "despótica" sobre a qual se assenta a governamentalidade biopolítica. Já se identificou no mercado a esfera de verdade que produzirá a norma de criação do sujeito neoliberal. Interessa ver como funciona a verdade de onde brota a norma criadora da subjetividade iurdiana que se pretende investigar.

\title{
3.3
}

\section{As gaiolas simbólicas do homem iurdiano.}

O homem iurdiano, esse "empresário de si mesmo, sócio de Deus", é um sujeito que inscreve sua existência em duas esferas de valores; de dois espaços de verdade, de onde se extrai o aparato normativo que ele aplicará voluntariamente à própria vida. De um lado, se ele é um sujeito neoliberal, movido pelos próprios desejos e próprias dores, pautado pela vontade de participar do mercado e da verdade que esse mercado proclama através da necessidade de eficácia e do despotismo da concorrência, ele também tem sua vida atravessada pelo universo simbólico do credo iurdiano. Seu catecismo se assenta sobre aqueles elementos já mencionados no capítulo 1: guerra santa, ética da vitória, fé inteligente e teologia da prosperidade.

Para entender como se forma a mentalidade do homem iurdiano, pode-se imaginar, como metáfora, duas gaiolas que o prendem: a gaiola dos valores simbólicos do sujeito neoliberal e a gaiola dos valores simbólicos da IURD. O 
homem iurdiano adentra voluntariamente nessas gaiolas, lá se encerra e nesse ambiente constrói o sentido que deseja dar à sua vida. Em tais gaiolas, o sujeito fica a sós com seus objetivos, e opaco a tudo que é diferente deles.

Ambas as gaiolas são proclamadoras de verdade. A primeira, proclama as verdades do mercado: as suas vantagens, o seu funcionamento, a satisfação prometida aos que nele se arriscam de maneira adequada, etc., A segunda gaiola proclama as verdades divinas do credo da Universal: "Deus prometeu abrir as portas dos céus nesta vida. Deus quer derramar as bênçãos sobre você, bastando apenas que se estabeleça com Deus a sociedade que ele oferece". A salvação iurdiana figura, assim, como algo não muito diferente do mercado se observado seu fim: uma oportunidade de obtenção de satisfação maior, seja pelo lucro, pelo consumo, pelo status de empresário, em suma: pelo transformar-se naquilo que se deseja ser - o empresário - para a partir dessa forma realizar aquilo que se deseja realizar.

Esse paralelismo possível entre a ética do mercado e a ética iurdiana não é imediato, por certo, e nem pré-determinado. O elemento que vai conectar a verdade divina, dogmática e religiosa do fiel com a norma mercadológica do sujeito neoliberal reside no elemento mágico, característico do pentecostalismo, mas que no neopentecostalismo sofre uma considerável ressignificação. Com efeito, tanto o pentecostalismo quanto o neopentecostalismo enfatizarão o papel do Espírito como elemento da manifestação divina no mundo, cada um à sua maneira. $\mathrm{O}$ elemento mágico, na guerra santa e na teologia da prosperidade, por exemplo, vai dar uma interpretação "teológica" à ação do empresário no mercado. No neopentecostalismo característico da Igreja Universal, portanto, é necessário entender como o espírito santo "opera" no fiel como o mercado opera no empresário, de maneira que se identifique aí a norma produtora da subjetividade do homem iurdiano: uma norma que combina elementos da verdade formada no mercado com a verdade formada no credo religioso.

O mágico enquanto ferramenta de coesão entre as duas gaiolas pode ser interpretado de três maneiras distintas: por meio da reafirmação da "vitória" no mercado como representação da benção fruto da sociedade com Deus; da reafirmação da "derrota" no mercado como efeito da ação do mal na vida do fiel (e reenfatizando aqui o papel que a guerra santa desempenha nesse processo) e por 
fim, o mágico como instrumento litúrgico, capaz de dialogar afetiva e psicologicamente com o fiel e aproximá-lo da ética da igreja ${ }^{102}$.

A todo momento, a igreja instrui seus fiéis nas duas gaiolas: seja nos cultos, investindo pesadamente na simbologia da guerra santa e seu desfecho de benção ou de maldição imediata na vida; seja nas palestras, seminários e eventos que administra em paralelo à liturgia. Toda a "carga" teológica da tradição cristã é canalizada num discurso normativo de admoestação aos fiéis a uma vida religiosa pautada pela autorrealização e satisfação dos próprios desejos, fazendo com que a igreja funcione como uma instituição de cura divina, naturalmente, mas também como um espaço pedagógico de construção do sujeito.

O caráter normativo no momento da produção do sujeito permanece constante na igreja. No culto de 20 de abril de $2018^{103}$, um bispo, identificado como Renato, reafirma a necessidade da obediência através da fé para o afastamento de toda dúvida e toda atitude vacilante. Aqui se está diante da "peneira" dessingularizadora que Judith Revel explica, reforçando também a figura da "fé inteligente":

"Fé é obediência! Amém? Preste bastante atenção no que eu vou falar pra você. Tem pessoas que pensam assim: 'poxa, eu queria ter uma fé como a do bispo Macedo... Eu queria ter mais fé! Eu queria ser uma pessoa de muita fé. Eu queria que Deus aumentasse a minha fé!' e ela pensa que ter mais fé envolve ela sentir alguma coisa, ela chorar na reunião... ela sentir um ímpeto! Algo diferente! Que ela vai ouvir uma voz ou que Deus vai aparecer para ela e não tem nada a ver com isso... Nada a ver. Fé tem a ver com uma coisa: obediência à palavra de Deus. Só isso; isso é fé. Amém? Quando a palavra de Deus fala 'Faça isso!' e você, mesmo contrariado, mesmo 'ah eu não acho que vá acontecer!' mas você faz! Ali você mostrou o quê? Fé! Deu pra entender? Sim ou não?

[O bispo cita o exemplo da cura do cego, contida em João, $9^{104}$, ressaltando como o cego obedeceu às ordens de Jesus para lavar-se no tanque.]

\footnotetext{
${ }^{102}$ Sobre exemplos mais detalhados de mecanismos litúrgicos empregados pela IURD para despertar o "psicológico" do fiel, remeto ao trabalho de Guiterrez (2017), que realizou pesquisa de campo nos templos da igreja. O capítulo 9 em especial é muito rico em exemplos.

${ }^{103}$ Disponível em https://www.youtube.com/watch?v=FnjFRkxAI4o\&t=4237s

104 "Ao passar, Jesus viu um cego de nascença. Seus discípulos lhe perguntaram: 'Mestre, quem pecou: este homem ou seus pais, para que ele nascesse cego?' Disse Jesus: 'Nem ele nem seus pais pecaram, mas isto aconteceu para que a obra de Deus se manifestasse na vida dele. Enquanto é dia, precisamos realizar a obra daquele que me enviou. A noite se aproxima, quando ninguém pode trabalhar. Enquanto estou no mundo, sou a luz do mundo'. Tendo dito isso, cuspiu no chão, misturou terra com saliva e aplicou-a aos olhos do homem. Então disse-lhe: 'Vá lavar-se no tanque de Siloé'. $\mathrm{O}$ homem foi, lavou-se e voltou vendo. Seus vizinhos e os que anteriormente o tinham visto mendigando perguntaram: 'Não é este o mesmo homem que costumava ficar sentado, mendigando?' Alguns diziam que era ele. Outros diziam 'Não, apenas se parece com ele', mas ele próprio insistia:
} 
"Fé é isso! Obediência! Amém? Eu vou, agora, chamar você à obediência, chamar você à fé. Nós vamos fazer uma oração de 'abre caminhos' aqui para você que precisa de um caminho aberto na sua vida financeira. Eu vou pedir a todos os pastores e bispos, obreiros, pra formar um corredor aqui de 'abre caminhos'... um corredor de luz! E antes de você passar no corredor você vai apresentar a sua oferta. A bíblia diz que a oferta, o presente, abre caminho! Amém? O presente abre caminho e nos leva na [sic] presença dos grandes. É o que está escrito lá no livro de Provérbios. Você vai apresentar agora a sua oferta do que você tem! Do que você tem aí com você, do que você tem através do seu cartão, do seu cheque, o que for! Você vai pegar aquilo que você tem, e você que precisa de um caminho aberto na sua vida financeira, você que está procurando um emprego e não acha. Você que precisa pagar uma dívida e não sabe como vai pagar. Você precisa encontrar uma forma de abrir um caminho para um negócio, para um contrato, para a sua empresa. Os seus caminhos financeiros estão fechados, mas você crê que Deus vai abrir esse caminho pra você. Então você vai pegar a sua oferta e vai obedecer à palavra, que diz que o presente abre caminho. Você vai dar o seu presente, ou seja a sua oferta para Deus, e ele vai abrir esse caminho."

É organizado então o corredor, montado pelos obreiros [todos de branco]. As pessoas da congregação montam uma fila numa das extremidades, esperando o momento de passar pelo caminho. $\mathrm{O}$ bispo permanece no púlpito, orando de cabeça baixa, pelas pessoas "que precisam de um caminho aberto na vida financeira"

O bispo dá as instruções: os obreiros que formaram o corredor deverão estender as mãos sobre os que passarão por ele. Os passantes, após lançarem a oferta, deverão atravessar o espaço delimitado mentalizando o caminho que desejam ver "aberto", ou seja, mentalizando a vitória. Chega um momento em que o bispo, mais uma vez enfatizando a necessidade de "dar um presente", diz "se você não tem nada para dar, nem um centavo, pelo menos arranque o botão da sua camisa, para dar uma atitude de fé. Nem que seja um fio de cabelo da tua cabeça: você vai dar!"

As luzes do templo se apagam. Só o caminho fica iluminado por um feixe roxo. Música intensa. Obreiros com braços estendidos sobre os fiéis que passam sob a voz do bispo, que determina "a bênção sobre a vida econômica" de cada um. Enfatiza, no discurso, o sofrimento do autônomo, do lojista, do que precisa de clientes, do que precisa que o cliente pague, do que precisa ter novas ideias para se reinventar. "Dê a essa pessoa coragem, dê a essa pessoa força, ousadia, intrepidez!" O discurso fica cada vez mais exaltado. "Miséria e maldição não passarão nesse caminho!" O processo do corredor dura bastante tempo, sempre sob os gritos do púlpito, terminando com um canto entoado por todos.

Nessa passagem, nota-se que o bispo desloca a fé de uma tradição cristã clássica como "ver Deus, sentir a presença do divino, etc." para outro patamar: a fé é o elemento do divino para, conforme o discurso, "abrir caminhos" na vida financeira do fiel. Esse elemento divino só é concedido por Deus aos seus sócios, ou seja, aqueles que conscientes da relação de crédito e obrigações que ligam Deus e homem na sociedade, dão prova da fé por meio de uma atitude (no caso, o lançamento da oferta). $\mathrm{O}$ aspecto mágico da fé aparece como costura entre os valores religiosos e os valores mercadológicos no discurso da Igreja Universal. A vitória é daqueles que ousam, que são intrépidos, que inovam, que se dedicam, mas

'Sou eu mesmo!'. 'Então como foram abertos os seus olhos?', interrogaram-no eles. Ele respondeu ' O homem chamado Jesus misturou terra com saliva, colocou-a nos meus olhos e me disse que fosse lavar-me em Siloé. Fui, lavei-me, e agora vejo' Eles lhe perguntaram: 'Onde está esse homem?' 'Não sei', disse ele" 
que também são fiéis (e fiéis inteligentes), pois compreendem na IURD o instrumento de guerra de Deus para o estabelecimento da sociedade com o homem e a derrota do Diabo na guerra santa. Os elementos "teatrais" - a luz bruxuleante, a música e os gritos - contribuem para moldar psicologicamente dos fiéis a comoção necessária à evangelização do credo iurdiano. O recurso ao livro dos Provérbios encerra o espetáculo como "verniz" teológico da prática.

A ênfase recorrente à ideia da obediência contra a dúvida revela, por um lado, a extrema capacidade de condução dos fiéis a determinada atitude. Afirma, também, a necessidade de disciplina dos fiéis para com a igreja e para com si próprios. Por outro lado, evoca outra lição já mencionada no capítulo 1: "A dúvida é do diabo". Fiel que duvida se afasta de Deus e permite que o Diabo entre na sua própria vida, se encaminhando, assim para uma derrota amarga na guerra santa. Sofrer uma derrota para o diabo significa perder as bênçãos que Deus prometeu. Essa obediência faz o fiel assumir seu lugar de "filho de Deus" como todos, mas ao mesmo tempo, singulariza-o como um vencedor, desde que tome a atitude para restaurar a sociedade com Deus.

Todo esse discurso, esses recurso psicológicos e a instigação ao desejo preparam, na "gaiola religiosa", o "terreno mental" do fiel para a modelação posterior pela educação mercadológica que a IURD proporciona, ou seja, a unificação existencial do fiel na forma empresarial. Paralelo à costura entre as duas gaiolas feita pela igreja por meio do elemento mágico e na conjuntura das celebrações, a IURD dispõe de um aspecto estrutural que promove a educação do sujeito fora da esfera litúrgica. Essa educação pode ser encontrada nos elementos já identificados como a Nação dos 318 ou no Congresso para o Sucesso Financeiro, mas igreja também faz questão de enfatizar a todo momento essa ligação entre a salvação prometida e o sucesso obtido por meio da forma empresarial nos seus meios de comunicação.

Em uma das palestras do Congresso para o Sucesso Financeiro ${ }^{105}$, o bispo Edson Costa (o mesmo da "aula-culto" na catedral de Fortaleza, mencionada no capítulo 1), faz uma apresentação da diferença entre "metas" e "objetivos", sempre

\footnotetext{
${ }^{105}$ Disponível em https://www.youtube.com/watch?v=VYShN_mDzn0. Não consegui identificar a data da palestra, mas o vídeo teve seu upload feito em 21 de junho de 2018.
} 
reforçando a ideia da necessidade de visão como o primeiro passo para empreender em qualquer coisa. "A primeira coisa que Deus faz: Deus dá ao ser humano uma visão, um objetivo, uma meta. Ele mostra ao ser humano onde ele pode chegar!"

\begin{abstract}
"Eu quero que você entenda hoje claramente a diferença entre uma meta e um objetivo. Suponhamos um arqueiro, com arco e flecha nas mãos, a 25 metros do alvo. Ele respira fundo, se concentra, retesa o arco e lança a flecha... Bum! Acertou no alvo, na mosca! Bem no centro do alvo. Dentro deste cenário que estou te mostrando, eu posso dizer para você que o alvo era o objetivo dele... porque o objetivo era acertar o quê? O alvo! E o percurso que a flecha trajetou [sic] até o alvo eram as metas dele para chegar até o alvo. Para que você entenda melhor: quantas metas e quanto ele teve que se preparar para alcançar o alvo? Eu não sei se você já viu um arqueiro, como ele faz? Não é só pegar uma flecha e lançar! Tem uma série de detalhes para que ele consiga alcançar o alvo! Você vê que depende da velocidade do vento... Ele tem que saber mais ou menos em que direção o vento tá soprando para não atrapalhar o quê? O trajeto da flecha! Ele tem a postura do corpo, certinha na maneira como ele tem que ficar: barriga pra dentro, peito pra fora, cabeça bem levantada! Ele tem que estar concentrado. Nada pode tirar a atenção dele. Ele tem que saber a força exata que ele vai fazer. E pra isso ele tem que ter a exata distância de onde ele está. Então ele tem que ter noção de distância, de força, o peso da flecha, concentração! E o conjunto de tudo isso é que faz ele alcançar o quê? Seu objetivo: o seu alvo! Então, o caminho da flecha são as metas. $\mathrm{O}$ alvo: o objetivo.

Qual é o problema das pessoas dentro da igreja? Elas querem prosperar, mas elas não têm o objetivo claro de onde querem chegar. Muito bem! O meu objetivo é ser empresário? Então quais são as metas que eu tenho que traçar todo dia para me tornar um empresário amanhã? Tem pessoa que quer ser empresária, mas nunca, na vida, ela sequer teve curiosidade de pelo menos entrar no Google e perguntar assim 'como se faz para abrir uma empresa?' Nem isso ela fez! Nunca ela procurou um contador para perguntar 'vem cá, para eu abrir uma empresa, do que eu preciso?' Para ele dar as direções: 'Olha, você vai ter que ir lá na junta comercial, vai ter que criar um CNPJ, vai deixar de ser pessoa física e virar pessoa jurídica, tem que ter nome fantasia, tem que ter razão social, tem que fazer isso e aquilo e aquilo outro' ou seja, as metas traçadas para chegar ao meu objetivo! Então às vezes a pessoa entra na casa de Deus mas nem ela sabe exatamente o que ela quer. Nada acontece por acaso, e Deus não vai fazer aquilo que eu tenho que fazer!"
\end{abstract}

Em seguida, o bispo dá três exemplos de pessoas que planejaram, se aperfeiçoaram e, por meio das metas, conseguiram chegar aos seus objetivos. Os exemplos citados foram os do artilheiro Marcelinho Carioca, do jogador Michael Jordan e, o mais curioso deles, o de Kate Middleton, esposa do príncipe William do Reino Unido, neto da Rainha Elizabeth II. Segundo o bispo, Kate sempre teve o objetivo de ser uma princesa e para tanto, se esforçou e realizou várias metas até atingir o seu objetivo.

Para além de eventuais exageros, a menção do "Caso Kate" como um exemplo de metas e objetivos é importante pois mostra a ênfase que a igreja dá na importância de uma agregação de valores e saberes do indivíduo para consigo mesmo e às suas próprias custas a fim de perseguir a máxima eficácia para atingir 
seu objetivo (afinal, "Deus não vai fazer aquilo que eu tenho que fazer", conforme o bispo).

\begin{abstract}
"Sabe a princesa Kate? A Kate Middleton, que casou com o príncipe lá da Inglaterra? Você vê que quando ela casou, todos os noticiários falavam a mesma coisa: 'uma plebeia casou com um príncipe! Uma pessoa da ralé, em outras palavras, casou com alguém da família real! Como é que pode?!' Mas ela não caiu de paraquedas ali... Quando você vê a história dessa menina, você vai vendo as metas que ela foi traçando desde criança para chegar ao seu objetivo. Desde pequena ela já falava para a mãe dela: 'Mãe, eu vou ser princesa! Eu vou casar com o príncipe! Eu vou fazer parte da realeza!' E a mãe dela apoiou o sonho dela; nunca duvidou. Então ela desde criança fazia recortes de todos os noticiários desse príncipe, desse camarada, ela cortava as fotos e deixava no quarto penduradas nas paredes, no teto, e todos os dias ela olhava para aquela foto e dizia 'eu vou casar com esse camarada! Eu vou ser princesa!' E ela começou a fazer cursos de como se portar, cursos de como se sentar a uma mesa, de como comer com a realeza, enfim, esses cursos de gente chique... Porque ela queria entrar na família real, então ela começou a aprender como seria estar, ela já começou a se enxergar na família real e começou a trabalhar em cima disso! Ela fez de tudo até conseguir entrar no mesmo colégio em que ele estudava. Ela começou a pesquisar que tipo de mulher ele gostava... qual era o perfil de mulher que ele gostava e começou a se tornar esse tipo de mulher! Então você veja que ela tinha esse objetivo, mas para chegar lá ela foi traçando o quê? Todos os dias uma meta diferente! 'Eu tenho que fazer isso, eu tenho que fazer aquilo e aquilo, porque quando chegar a oportunidade eu tenho que estar pronta para aproveitá-la! E veio o dia da oportunidade: eles se conheceram e ela já estava pronta e ta aí: a mulher hoje é princesa!
\end{abstract}

Então não foi por acaso! Não caiu de paraquedas! O objetivo veio sendo traçado por metas, então o caminho da flecha até o alvo foi ela que fez acontecer!"

A metáfora do arqueiro e o exemplo da "menina que queria ser princesa" (para além da plausibilidade quase fantasiosa), mostram algumas operações interessantes do processo de construção do sujeito neoliberal na IURD.

Em primeiro lugar, o sujeito deve olhar para si próprio como uma máquina potente, capaz de fazer cálculos de desejos e riscos inerentes ao processo de obtêlos. Em seguida, é necessário o domínio da visão, que envolve o desejo e o know how para atingi-lo, que o bispo decompôs na operação de "metas" e "objetivos". Em segundo lugar, finda a metáfora do arqueiro, o bispo vai direto ao ponto objeto do desejo: ser empresário ${ }^{106}$. O vocabulário empregado é todo voltado para o momento do nascimento empresarial ("junta comercial", "CNPJ", "pessoa jurídica", "contador"). Em terceiro ponto, e talvez mais incisivo, vem o processo do domínio das técnicas de si, do autocontrole, da disciplina autoimposta, da descoberta dos saberes práticos (no caso de Kate, o "saber sentar-se à mesa", saber o "tipo de

\footnotetext{
${ }^{106}$ Lembrando que na "aula-culto" de Fortaleza, o bispo já tinha ironizado as pessoas que iam à igreja buscando um emprego melhor ou um salário mais digno ("É esse Deus que você veio procurar aqui?"). Trata-se de um público que busca ser mais do que aquilo que é, e que vê na forma da empresa o caminho e o destino que almejam para si, conforme explicado no final do capítulo 1 .
} 
mulher que o príncipe gosta", etc.), e o aperfeiçoamento desses saberes buscando a máxima eficácia. O caso Kate, apesar da anedota grotesca, é um exemplo da formação do sujeito enquanto "capital humano".

Essa ideia de capital humano no homem neoliberal é investigada por Dardot e Laval, sempre lembrando que o "capital humano" só é válido se utilizável, de modo que o sujeito neoliberal enquanto "capital humano" é um indivíduo que "vive para o outro", fazendo com que o bem do outro (da empresa) seja o seu próprio bem e vice-versa (Dardot; Laval, 2016, p. 327) ${ }^{107}$. Da mesma forma que os bens que Kate proporciona a William são bens que ela gera a si própria, o indivíduo que se promove nas técnicas de si (se capitaliza) gera um benefício para a empresa como se fosse a ele mesmo que o fizesse.

Por fim, o quarto elemento é o Divino, o mágico: Deus não vai fazer por você o que só você pode fazer por si mesmo. É necessário, portanto, que o fiel tome a atitude para provocar o divino a agir para cumprir com as suas obrigações dentro da "sociedade".

Em outro episódio, o bispo Edson Costa dá uma nova lição ${ }^{108}$, enfatizando a necessidade da ação humana, da atitude e da agência para atingir três objetivos: a posição de empresário desejada; a prosperidade financeira perseguida e, por fim sempre o elemento simbólico do mágico - a benção de Deus na sua vida:

\footnotetext{
"O que nós mais temos são colecionadores de conhecimentos que não saem do lugar. Pessoas que colecionam conhecimento, colecionam diplomas, colecionam cursos, porém elas não tomam atitude nenhuma e, por isso, a vida delas está parada, estagnada. Nós cansamos de ver aqui mesmo nessa reunião pessoas que não têm conhecimento nenhum, que não têm habilidade nenhuma, PORÉM são pessoas de atitude! E hoje estão aí fazendo a diferença: se tornaram empresários bem-sucedidos porque na atitude Deus fez toda a diferença na vida delas. "
}

\footnotetext{
107 "A vontade de realização pessoal, o projeto que se quer levar a cabo, a motivação que anima o 'colaborador' da empresa, enfim, o desejo com todos os nomes que se queira dar a ele é o alvo do novo poder. O ser desejante não é apenas o ponto de aplicação desse poder; ele é o substituto dos dispositivos de direção das condutas. Porque o efeito procurado pelas novas práticas de fabricação e gestão do novo sujeito é fazer com que o indivíduo trabalhe para a empresa como se trabalhasse para si mesmo e, assim, eliminar qualquer sentimento de alienação e até mesmo qualquer distância entre o indivíduo e a empresa que o emprega. Ele deve trabalhar para a sua própria eficácia, para a intensificação de seu esforço, como se essa conduta viesse dele próprio, como se essa lhe fosse comandada de dentro por uma ordem imperiosa do seu próprio desejo, à qual ele não pode resistir. [...] obedecer ao próprio desejo ou ao Outro que fala em voz baixa dentro de nós dá no mesmo."

108 Disponível em https://www.youtube.com/watch?v=s3mp7qfd-RE\&feature=youtu.be. Não consegui identificar a data da palestra, mas o vídeo teve seu upload feito em 01 de abril de 2018.
} 
Mais adiante, o bispo retoma o esquema da tomada de posse das bênçãos prometidas por Deus explicado no capítulo 1 para reforçar o argumento:

Depois que a pessoa tem acesso às promessas de Deus, por exemplo, 'Abrirei as janelas dos céus e derramarei sobre vós bênçãos sem medida! O Senhor é meu pastor e nada me faltará!' Então depois que ela conhece essas promessas, a impressão que dá é que ela cruza os braços e fica esperando com que isso aconteça na vida dela sem que ela faça nada! [...] Então às vezes ela quer que caia do céu algo que não vai cair sem ela tomar uma atitude!

O bispo faz uma reflexão sobre a leitura do capítulo 2 da Carta de Tiago, especialmente a partir do versículo $17^{109}$, sobre a questão de fé e de obras de fé, para interpretar essas como necessárias à ação humana e a consequente salvação:

"Então olha o que Tiago estava dizendo: 'poxa, o que adianta eu dizer que eu tenho fé, sendo que as minhas atitudes, o meu comportamento, a minha postura mostram o contrário?"'

Em um determinado momento, o bispo enfatiza o papel pedagógico da igreja na construção da conduta do fiel, do ponto de vista do fiel funcionário, e do ponto de vista do fiel empresário:

"Mas o que é que ele [o fiel] aprende aqui dentro [dentro da IURD]? Ele aprende a ser o pior ou aprende a ser o melhor? Aqui dentro ele aprende o seguinte: olha, se você é funcionário, então vista a camisa da empresa, dê o seu sangue, trabalhe com toda a sua força, seja o melhor, porque se amanhã ou depois você for patrão, você vai saber como fazer a coisa! Você que é patrão, a gente ensina você: olha, você é patrão? Trate todo mundo bem! Trate todo funcionário com dignidade, com justiça! Porque Deus vai te honrar! Faça pelo próximo porque Deus disse que abençoaria quem te abençoasse! Mas às vezes o camarada é um carrasco, ele chega na empresa com o chicote na mão e todo mundo tá tremendo! Não é o que ele aprende aqui dentro!"

Sobre a questão da "derrota" nas atitudes, o remédio é a fé inteligente, a fé acompanhada de atitude:

"'Foi injustiçada!'; Ao invés de ficar chorando e se lamentando pelos cantos: 'Não tem problema! Um justo juiz vai julgar minha causa! Deus é comigo! Eu não vou depender do Homem e nem de filho de Homem! É Deus quem vai fazer a diferença!' Então ela coloca essa fé em prática, ela coloca essa fé para funcionar! A fé não tá num guarda-roupa, guardadinha. A fé é pra ser usada!"

O bispo conta então um exemplo de "vitória" a partir do testemunho de uma fiel que tomou atitude sobre a sua própria vida, instigando aos fiéis novamente a ética da vitória:

"A senhora do testemunho disse 'eu comecei dentro de casa, com um fogãozinho de duas bocas que só funcionava uma!Mas comecei fazendo marmitex. Fui vendendo pra um, pra outro... não sabia nem cozinhar, só sabia fazer miojo, mas eu comecei!' Olha o que é atitude! Deus começou a criar situações, criar situações, criar situações... o dono do mercado vendeu pra ela o mercado sem ela pagar um centavo! Foi pagando com serviço e foi crescendo, crescendo, crescendo, porque quando Deus vê atitude ele faz questão de honrar! Fé acompanhada de obras!" Atitude em relação à vida, atitude em relação a você! Como você

109 "Assim também a fé, por si só, se não for acompanhada de obras, está morta. Mas alguém dirá: 'Você tem fé; eu tenho obras'. Mostre-me a sua fé sem obras, e eu lhe mostrarei a minha fé pelas obras. Você crê que existe um só Deus? Muito bem! Até mesmo os demônios crêem — e tremem! Insensato! Quer certificar-se de que a fé sem obras é inútil? Não foi Abraão, nosso antepassado, justificado por obras, quando ofereceu seu filho Isaac sobre o altar? Você pode ver que tanto a fé como as suas obras estavam atuando juntas, e a fé foi aperfeiçoada pelas obras. Cumpriu-se assim a Escritura que diz: 'Abraão creu em Deus, e isso the foi creditado como justiça', e ele foi chamado amigo de Deus. Vejam que uma pessoa é justificada por obras, e não apenas pela fé. Caso semelhante é o de Raabe, a prostituta: não foi ela justificada pelas obras, quando acolheu os espias e os fez sair por outro caminho? Assim como o corpo sem espírito está morto, também a fé sem obras está morta. 
se enxerga! Quando você se olha no espelho, ao invés de ficar se lamentando, fale 'poxa, eu sou um filho de Deus! Eu vou sair dessa! Eu não sou um derrotado, eu posso estar derrotado, mas eu não sou um derrotado!', poxa, 'Eu não sou um microempresário: eu sou o dono de uma microempresa!' É diferente uma coisa da outra: eu sou dono de uma empresa pequena mas eu não sou pequeno! Daqui a pouco ela vai crescer!"

No exemplo destacado acima, ressalta-se o paralelismo que o bispo Edson faz entre conhecimento e a fé "com atitude" encontrada no discurso do bispo Renato, páginas acima. A fé só é verdadeira ser for posta em prática, se for útil, se for "inteligente". Da mesma forma o conhecimento só tem valor se for convertido em atitude, em agência. $\mathrm{O}$ conhecimento adquirido e posto em prática permite ao sujeito neoliberal dar um passo à frente dos seus concorrentes, e portanto todo conhecimento só tem validade na sua utilidade. Em paralelo, a fé com atitude aproxima o fiel de Deus. Aqui, discurso mercadológico e religioso se encontram e se retroalimentam. Nessa conjugação de fé e agência as duas gaiolas do homem iurdiano se comunicam. O conhecimento adquirido, o espírito vitorioso e a fé inteligente preparam o sujeito para a aventura empresarial que começa no marmitex e termina no mercado.

Para além do púlpito, a IURD mantém a sua capacidade invejável de se comunicar com os fiéis fazendo uso corrente da internet e das redes sociais. Por exemplo, a Folha Universal tem sua própria página no facebook ${ }^{110}$ também pelo site oficial da igreja ${ }^{111}$ e por outro site, o "Eu sou a Universal"112, que traz depoimentos e testemunhos de fiéis sobre suas experiências na igreja

A presença constante do discurso empreendedor, tomando o fiel que deseja ser empresário por alvo e o sucesso financeiro como escopo, permanece nitidamente no jornal oficial da igreja. Tome-se a matéria publicada na Folha Universal, número 1.359 (22 a 28 de abril de 2018), chamada Qual a sua relação com o dinheiro?, da qual trechos seguem copiados abaixo:

"Mesmo que alguns não acreditem na Bíblia, é inegável que nela encontramos os conceitos mais antigos de prosperidade e as leis das maiores sociedades do mundo. A Bíblia

\footnotetext{
110 A página da "Folha Universal" no facebook (https://www.facebook.com/FolhaUniversal/) contava com 131.752 "curtidas" e 130.941 seguidores em fevereiro de 2018.

${ }^{111}$ https://www.universal.org

$112 \mathrm{http}: / / \mathrm{www} . e u s o u a u n i v e r s a l . c o m /$
} 
nos ensina de diversas formas sobre gestão de pessoas e finanças. É só olhar para a história do povo hebreu e nela encontraremos vários exemplos de prosperidade.

José do Egito de escravo tornou-se governador. Ele sabia lidar com o fluxo de caixa de uma empresa, um dos principais problemas dos empreendedores nos dias atuais. José, segundo a Bíblia, teve a direção de armazenar alimento nos dias de fartura para ter provisão nos dias de escassez.

Davi foi um caso de superação e liderança. Ele provou que o sucesso não é apenas para alguns, mas para todos. As mulheres também são grandes exemplos, entre elas Rute e Ester. Elas eram dotadas de capacidades administrativas e de sensibilidade para gerir pessoas e solucionar conflitos e problemas. Qualidades essenciais para o sucesso.

Apesar de suas diferenças de idade, culturais, de classe social, esses personagens bíblicos seguiram o mesmo caminho: acreditar em Deus e usar a sabedoria para serem prósperos e ótimos administradores."

Desde a Criação, Deus deixou claro que deseja que sejamos prósperos. É o princípio da multiplicação: não há fruto sem semente. Os animais procriam, os seres humanos são dotados de inteligência, tudo foi pensado em torno do crescimento e da expansão. Mas muitos cristãos se esqueceram desses princípios de sucesso e prosperidade e confundiram os conceitos de humildade e pobreza e de riqueza e orgulho, criando uma visão ruim do dinheiro e inconscientemente se afastando do equilíbrio

$[\ldots]$

É necessário abandonar a 'culpa cristã' e acreditar nas promessas de Deus para a vida financeira. É possível e totalmente correto ser próspero e ser cristão."

$\mathrm{Na}$ mesma edição, logo abaixo, o jornal traz as "10 características empreendedoras de David" avisando: "Davi não tinha, aos olhos humanos, a menor condição de ser rei": 


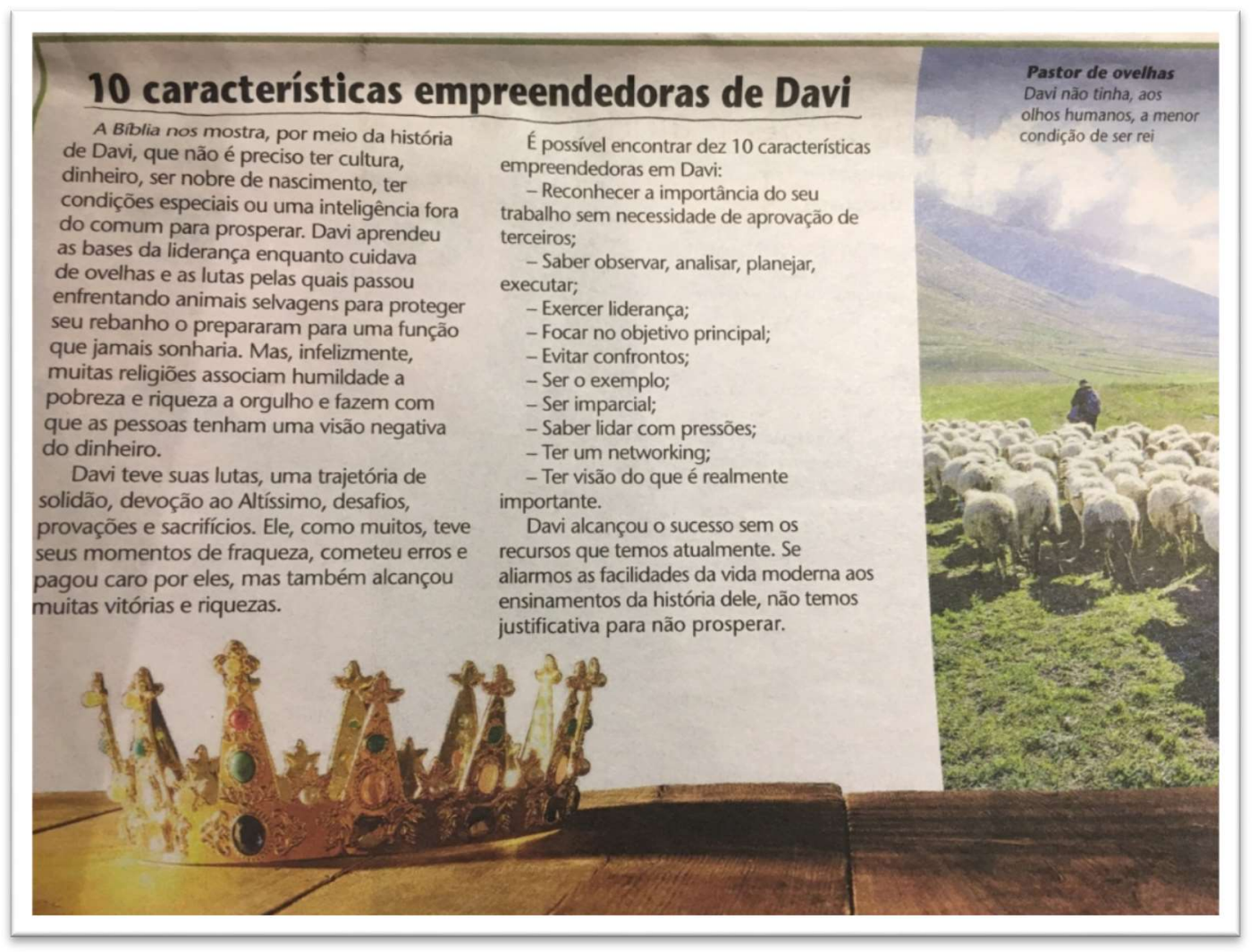

Ressalto as características "liderança", "focar no objetivo principal" e "ter visão do que é realmente importante" (que se conectam imediatamente com a palestra do bispo) e também dois itens que gostaria de destacar: "saber lidar com pressões" e "ter um networking". Esses dois itens são interessantes para o raciocínio porque, além de serem "características empreendedoras por excelência", são dois pontos explorados com constância dentro da igreja.

Por meio do "Eu sou a Universal", a igreja organiza uma coleção de histórias de fiéis que registram sua vida pessoal, suas ambições, frustrações e vitórias, e principalmente como a igreja os ajudou nesse caminho. Os perfis são bastante amplos em idade, gênero, ocupação, origem geográfica e social, mas todos tiveram uma posição de destaque na vida profissional. A igreja, por via indireta, acaba criando ali um "banco de dados" de profissionais das diversas áreas e, consequentemente, um ponto de referência dos fiéis para o networking, fundamental para a atividade empresarial.

Os casos eram múltiplos. O do sushiman, o do peão de rodeio, do animador de festas, etc. Escolhi dois, para um breve exemplo, pois se intitulam como 
empresários/empreendedores: o caso de Gustavo Boccoli ${ }^{113}$, que se apresenta "Eu sou o Gustavo Boccoli. Casado. Pai. Empreendedor. Sou jogador de futebol. Eu sou a Universal!" e o de Daniela Dobroca ${ }^{114}$, que se apresenta como "Eu sou a Daniela Dobroca. Tenho 36 anos. Sou empresária e dentista. Eu sou a Universal!"

No registro do depoimento de Gustavo, são notórios os paralelismos com o discurso do bispo Edson Costa, citados acima, no sentido de se adotar uma prática para si, ensaiá-la, desenvolvê-la, trabalhar sobre si mesmo em etapas até chegar ao destino final. No caso de Gustavo, que praticava futebol profissionalmente desde criança e que terminou a carreira como melhor jogador do time vencedor de um campeonato israelense, a vida foi complementada pelo papel de empresário:

"Porém além do esporte, hoje também desenvolve suas habilidades como empreedendor. 'Gosto muito de investir em imóveis, comprar terrenos, construir, para depois vender. Descobri que também tenho dom para os negócios imobiliários"'.

O caso de Daniela, que também se apresenta como empresária além de dentista, envolve o domínio de si, o esforço em busca da eficácia e tomada de atitude para perseverar no objetivo final:

\begin{abstract}
"Amar sua profissão pode ser o grande diferencial na vida de quem deseja ser bemsucedido. E é isso o que acontece comigo, o que é normal quando se luta muito por uma conquista. Quando se vive em função de um desejo, valorizamos cada detalhe.

$[\ldots]$

Sou filha única de um casal de retirantes e tive uma infância humilde, mas também com muitos momentos bons e inesquecíveis. Foi na adolescência que decidi qual carreira seguiria, independentemente do sacrifício que teria de fazer. Havia um conhecido da minha família que tinha um consultório de odontologia e nas férias eu ia até lá para ajudar como voluntária. Eu ajudava no trabalho com total dedicação e cada dia mais pegava gosto pela profissão! Ali eu me transformei na doutora Daniela Dobroca. Ainda não tinha uma formação, nem trabalho, nem consultório e muito menos pacientes. No entanto, dentro de mim já havia dado asas ao sonho."
\end{abstract}

Já na página virtual do jornal "Folha Universal", os esforços são os de proporcionar um maior controle psicológico dos fiéis-leitores diante de uma situação de estresse ou adversidade na profissão. Na matéria "Você é

\footnotetext{
${ }^{113}$ Encontrado em http://www.eusouauniversal.com/depoimentos/gustavo-boccoli/

${ }^{114}$ Encontrado em http://www.eusouauniversal.com/depoimentos/daniela-dobroca/
} 
emocionalmente inteligente no trabalho? ${ }^{115 "}$ é transcrita a entrevista que um coach forneceu ao jornal, relatando as causas, consequências e adversidades do estresse, e métodos de contorná-lo por meio da "inteligência emocional".

"Então, como superar as pressões e dificuldades do cotidiano e também ter êxito na carreira? Para o life and professional coach Emanuel Quiroz, de 53 anos, o desenvolvimento da inteligência emocional (IE) é uma das formas de concretizar esses objetivos. "Ela vale tanto para quem é empregado quanto para quem é empresário. Esse conceito, que envolve compreender e gerenciar os próprios sentimentos e também os sentimentos das pessoas à nossa volta, nos ajuda tanto na vida pessoal quanto em nosso trabalho e nos permite avaliar e construir soluções com mais eficiência e menos sofrimento", explica.

Para o especialista, o primeiro passo para aplicar a IE é se conhecer melhor. "É preciso fazer uma avaliação pessoal minuciosa e sincera de quem somos para identificarmos em quais aspectos somos mais fortes e mais fracos. A partir disso é possível começar a praticar a inteligência emocional. Muitas pessoas já possuem naturalmente algumas características da IE, mas isso não quer dizer que outras capacidades não possam ser adquiridas ou desenvolvidas. Suas limitações podem ser temporárias se você buscar ativamente mudar para melhor", avalia.

Quiroz afirma que nossa percepção também deve considerar quem está ao nosso redor. "É preciso desenvolver a capacidade de imaginar o que o outro sente, nos colocarmos no lugar dele e percebermos quais são suas demandas. Isso facilita nossa aproximação e nos dá a possibilidade de fazermos melhores negócios, pois nos comunicamos e compreendemos melhor o outro."

A matéria é encerrada com um desenho representando um esquema de uso da "inteligência emocional" para principiantes:

\footnotetext{
${ }^{115}$ Disponível em https://www.universal.org/blog/2019/01/20/voce-e-emocionalmente-inteligenteno-trabalho/
} 

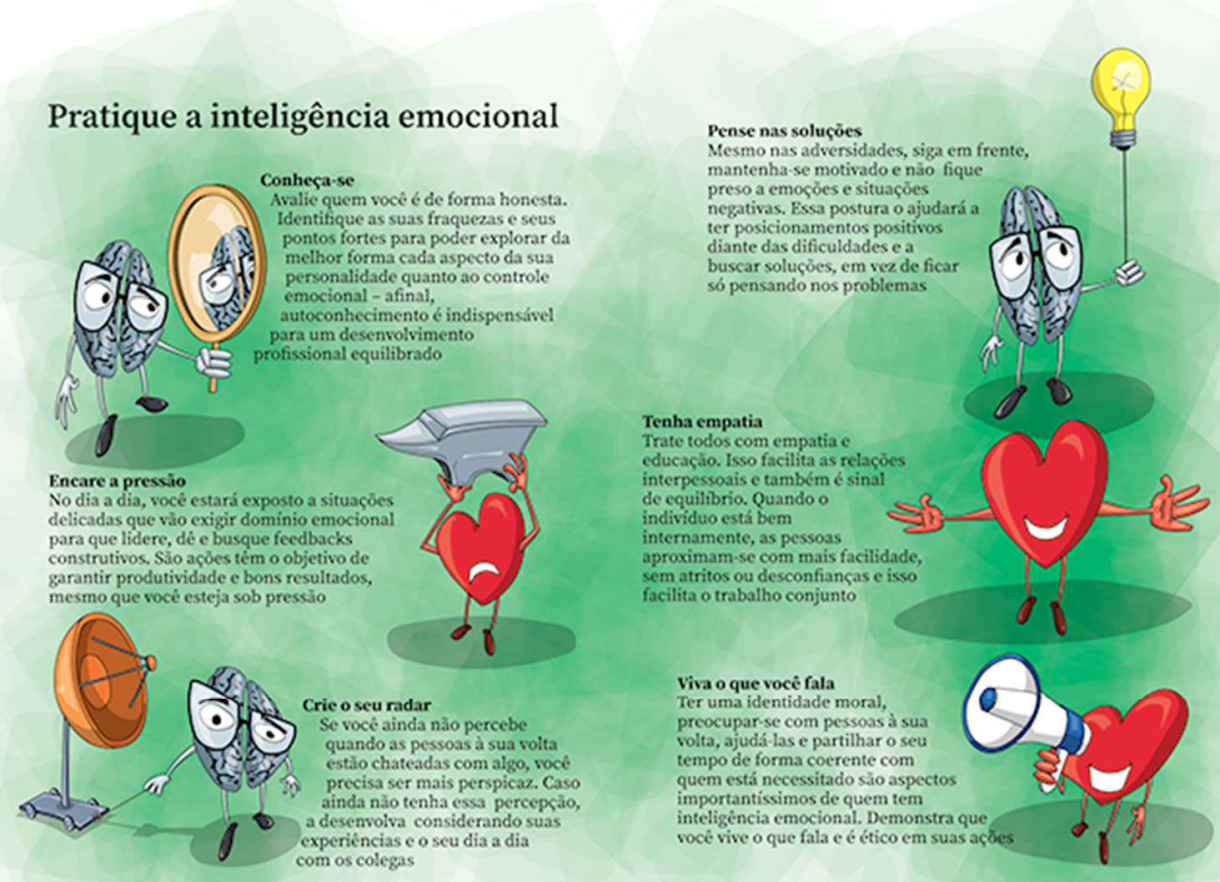

É perceptível no discurso do coach a questão do governo do homem neoliberal pelos prazeres e pelas dores do qual Dardot e Laval falavam. Em primeiro lugar, os prazeres e dores de si próprio, quanto às próprias "vitórias" e "fracassos". Depois, os prazeres e dores alheios, sejam da empresa ou do cliente, que devem ser elementos constantes no cálculo do prazer ou dor do próprio sujeito, completando, assim, a sentença já mencionada: "obedecer ao próprio desejo ou ao Outro que fala em voz baixa dentro de nós dá no mesmo."

Situação semelhante foi a de Daniela Debroca, que começou colocando o desejo como motor inicial para a mudança de vida, e terminou vendo na ajuda ao consultório onde trabalhava uma forma de ajudar a si própria. Soube canalizar o saber, soube construir a si própria e, com a ajuda da igreja, hoje é empresária.

\section{4}

\section{A construção do homem iurdiano.}

O processo de construção do homem iurdiano é produto do mecanismo normativo exposto acima, que por sua vez, opera pela discurso da igreja, mas 
também é refletido na sua estrutura e no modo como essa se organiza. Um indivíduo que atravessa as portas de um templo da Universal está ali por razões religiosas, naturalmente, o que envolve dizer que busca um maior contato com o divino, o sagrado e os elementos religiosos. O que o diferencia do fiel de qualquer outro credo é o que ele deseja que esse divino realize na sua vida, e que valores podem ser incorporados ao seu espírito a partir da experiência naquela igreja.

Quando o indivíduo adentra o espaço da IURD, se depara com as promessas esculpidas nos slogans da Igreja e das suas campanhas: "pare de sofrer!", "seja um vencedor" e também com os testemunhos de "fiéis vencedores", transmitidos pessoalmente ou por meio do "Eu sou a Universal". São mensagens como a de Gustavo e Daniela: vencedores, empresários, que realizaram seu sonho com a ajuda da igreja. Dessa, já está envolto pela simbologia iurdiana e reforçado pelos testemunhos, o indivíduo toma a decisão da conversão e submissão da sua vida ao projeto de bênçãos de Deus. O Deus que o fiel busca na Igreja Universal é o mesmo do qual o bispo Edson fala: um Deus que é grande e quer que seus filhos sejam grandes também. Um Deus que recompensa aos que ousam tomar atitude para mudar as suas vidas. Essa recompensa não é só promessa de santidade, de salvação do diabo. Conforme já exposto, as bênçãos também podem ser materiais, e nessa crença, a igreja incute ao homem um horizonte de desejo também material: o padrão de vida elevado, a posição de empresário, o luxo, a riqueza. "Tudo isso pode ser atingido por meio de Deus, basta que se tome atitude" Eis aí a primeira gaiola: o simbólico religioso da IURD.

No processo de conversão, o sujeito é chamado ao aprendizado da "fé inteligente": não clamar por ajuda; ajudar a si próprio. Nesse percurso, com a voz que ecoa do púlpito com estímulos à tomada de uma atitude, de um risco, de uma ação em direção à bênção prometida. O processo de dessingularização começa quando o fiel se convence a abandonar a vida que tinha antes e passar a se comportar como um filho de Deus e seu sócio em potencial. Já operada uma mutação no horizonte do desejo, o fiel agora se vê atravessado por outros valores, complementares ao primeiro: a sua responsabilidade exclusiva sobre suas vitórias ou derrotas, a consciência de uma ação racional para conquistar os objetivos pretendidos e a necessidade de observância às oportunidades de experiências e 
conhecimentos úteis que lhe podem servir de ferramenta ou de auxílio nessa aventura.

Seu comportamento muda. O fiel compreende que o destino da sua vida depende de si próprio, e para isso, deve tornar-se senhor de si próprio, por meio da forma empresarial. Em outras palavras, mudar de vida envolve mudar de si Conforme afirmou o bispo Formigoni no Congresso para o Sucesso Financeiro de 08 de maio de $2016^{116}$ "Você não precisa de uma melhora! Você precisa de uma reviravolta na sua vida financeira. Até porque se a sua vida melhorar, ela continua ruim. Não é isso?". O bispo Formigoni é conhecido pelo seu bordão "Se a sua vida não mudar, eu como a bíblia!", que usa para enfatizar a capacidade da Universal de mudar a vida do fiel.

O que a igreja faz por meio do seu discurso e por meio da sua estrutura é construir um modelo de fiel ideal, que por meio das práticas, da obediência, da disciplina e da ação, conquista a sociedade com Deus, e passa a cobrar d'Ele as promessas de abundância contidas na escritura. Os fiéis procuram se adequar a esse modelo; passam a agir conforme da prédica da igreja, passam a ver-se como o modelo, a se portar como o modelo, e todo momento o modelo fulgura como deverser. Essa é a segunda etapa da norma que Foucault fala e que Dardot e Laval explicam: a unificação existencial em torno do modelo segundo o qual a norma molda e controla os sujeitos. Ser como o modelo envolve deixar de lado tudo dentro do seu próprio eu que não está adequado ao modelo, dessingularizar-se, para depois, modelar-se.

Essa operação normatizadora é conduzida pela gama de poderes institucionais que a IURD utiliza para conduzir o seu rebanho. São mecanismos de estímulo como os exemplos bem-sucedidos no jornal, no site ou no testemunho prestado no altar, são também os instrumentos psicológicos como as fortes correntes de oração, os corinhos da Nação dos 318, as luzes e a música comoventes (como no episódio do corredor de "abre-caminhos"), ao som dos gritos dos pastores ordenando que o espírito de miséria abandone a vida daquelas pessoas. Também a cosmologia iurdiana promove uma explicação que estimula os fiéis a aterem-se veementemente ao modelo: preguiça, dúvida, derrota e fracasso são do diabo, e ele

\footnotetext{
${ }^{116}$ disponível em https://www.youtube.com/watch?v=MGMSEX-o7Ks\&feature=youtu.be
} 
possui vários demônios ao seu serviço, devendo o fiel ter isso em mente e sempre portar-se como um vencedor.

O poder controlador da igreja também está presente nos resultados que ela apresenta aos seus fiéis. Sempre exibindo o consumerismo como a marca da salvação, o já mencionado programa do Congresso de 8 de maio, bem ao início, dedica cerca de três minutos e meio à Ferrari, aos seus carros, ao custo dos carros, aos famosos que já têm uma (ou duas) e como Deus pode te ajudar a ter uma também.

No mesmo programa, são vários os depoimentos de fiéis que estavam na pior, com seus negócios amarrados pelo diabo, mas que deram a volta por cima em nome de Jesus, mas com a ajuda do Congresso. Todos eles empresários.

Diz o bispo Formigoni, com suas abotoaduras reluzentes, reforçando a necessidade de obediência à prédica iurdiana:

\begin{abstract}
"Eu vou colocar agora histórias reais. Pessoas que estão em ascensão, ainda não conquistaram tudo não. Elas estão subindo. À medida em que obedecem nesse congresso elas vão galgando novos horizontes. Elas vão subindo. Em breve você também terá uma nova história pra contar. [e, repetindo o bordão] Se você vir aqui no congresso e obedecer ao que eu vou falar e a sua vida não mudar, eu como a bíblia!"
\end{abstract}

Testemunho do Seu Lourenço, que passou por duas falências: em sete meses sofreu dez processos de despejo da casa onde morava, num condomínio fechado. Recuperou algo, voltou a enriquecer apenas para cair em outra crise. Acumulou uma dívida de três milhões de reais. A sua vida só mudou ao entrar na Universal e participar do Congresso:

\footnotetext{
"Deus começou a suprir as minhas necessidades. Paguei as dívidas. Primeiro arrumei um emprego e fui prosperando. Tive a coragem de novamente abrir uma empresa. Aí a coisa começou a ficar muito boa. Aí do nada, bispo, me veio a ideia de mudar totalmente o ramo de atividade. Há oito anos Deus vem me prosperando [sic], me enriquecendo. Hoje nós somos um dos maiores correspondentes bancários do país, trabalhamos para todos os bancos. Emprestamos milhões e milhões por ano e a minha vida... não tem o que falar! Meus filhos estão na presença de Deus. A minha família é uma mulher de Deus [sic], trabalha comigo. É minha sócia. Bens materiais? Hoje a gente tem, mais ou menos, uns trinta milhões de patrimônio: casas, carros, mansão. Meu filho menor que vai fazer 18 anos agora já tem um carro importado. Meu filho do meio, o último carro que ele comprou custa 250 mil reais. Ele comprou! Ele é sócio de uma empresa que eu tenho. Meu filho maior, que tem 27 anos de idade, hoje tem uma empresa no mesmo ramo que eu tenho. Acabou de nascer o filho dele e ele tem uma condição financeira muito boa. Eu não tenho mais o que dizer, né?"
} 
Seu Lourenço é um modelo.

O bispo retoma:

"O Deus que eu estou the apresentando aqui tira você do lixo e coloca numa situação de destaque. Nesse congresso, Deus está levantando aqueles que vão se sentar nas principais cadeiras desse país - escreve o que eu estou te falando! - Deus está levantando nesse congresso os novos bilionários desse país. Deus está levantando nesse congresso aqueles que vão tomar posse dos principais contratos desse país"

Testemunho da Dona Cléo, dona de uma loja de roupas quando perguntada "Qual é o papel do Congresso nisso tudo aqui?", referindo-se à sua posição como dona da loja.

\begin{abstract}
"Ah o Congresso é tudo na minha vida! É no Congresso que a cada dia eu tenho novas ideias assistindo às palestras. Eu saio de lá motivada pra chegar e colocar em prática a cada dia. O Congresso dá essa motivação. A gente vai, ouve a palestra e sai de lá... recarrega a 'pilha', recarrega as ideias... você sai com outro ânimo. Sai na certeza de que você vai fazer e vai dar certo. A cada dia eu to lutando, to vendo crescendo com muito trabalho, com muita luta e colocando em prática, como eu disse, na corrente do Congresso porque a gente tem uma motivação. Com a força dos seus braços você não vai a lugar nenhum"
\end{abstract}

Dona Cléo enfatiza a importância que o Congresso para o Sucesso Financeiro tem, não só como motivacional, mas principalmente como espaço de obtenção de novas ideias. Aqui entra outro papel fundamental da igreja na construção do homem iurdiano, que consiste na segunda gaiola: os valores do mercado e seu papel pedagógico.

Conforme exposto no capítulo 2, o sujeito neoliberal, empresário de si mesmo, assume para si os riscos da aventura mercadológica de busca de autossatisfação. Para aguçar o cálculo da Ação Humana, o empreendedor precisa aprender a gramática do mercado e principalmente, o processo de descoberta de oportunidades, habilidades e de domínio do conhecimento hábil a trazer resultados se posto em prática (knowledge).

Daí decorre a importância que a igreja dá às atividades para-litúrgicas como o Congresso visando a educação empresarial dos seus fiéis. Esse processo "educacional" não é só aprender estratégias de agência no mercado, mas também o domínio das "10 características empreendedoras de Davi", entre as quais liderança, criatividade, autocontrole e outros já mencionados. 
Aí começa a se formar o empresário de si mesmo, que vai procurar aperfeiçoar o domínio de si, dentro e fora da IURD, por meio de curso de línguas, controle emocional, desenvolvimento da inteligência emocional, aperfeiçoamento de técnicas profissionais, especialização acadêmica, expansão da rede de networking. O sujeito iurdiano passa a se aperfeiçoar, se controlar, e se vigiar para viver para outrem, porque assim se vive para si.

Essa busca pela autorrealização empresarial e pela maximização da satisfação modela o sujeito conforme a norma biopolítica da qual Foucault falava. O sujeito não se verá coagido a tornar-se empresário: tornar-se-á empresário porque vê nessa forma de vida uma possibilidade de maior satisfação para si próprio conforme a verdade emanada pelo processo mercadológico. O reducionismo existencial à empresa parece ser a única via verdadeira e possível à maximização dos prazeres e valorização da própria existência.

Evidentemente que nessa perspectiva jaz um forte apelo consumerista, ostentador de riqueza que para o mercado é um sinal de "boa educação" empresarial mas que, na IURD, é ressignificada como bênção divida. Por isso a lógica da teologia da prosperidade faz sentido para um fiel da IURD: "as bênçãos que Deus derramou sobre minha vida são sinais de que minha sociedade com ele foi restaurada.", pela lógica das promessas divinas, Deus dá a benção àquele que for fiel a ele. Por isso o dízimo figura como uma forma de "provocar" Deus a permanecer em sociedade, multiplicando as bênçãos e reforçando o esquema normativo que enclausura o fiel nas suas gaiolas.

\section{5}

\section{Síntese conclusiva}

Neste capítulo, procurei mostrar como se constrói o homem iurdiano, o sujeito neoliberal-neopentecostal cuja análise é objeto deste trabalho. Partindo do caminho aberto por Foucault, Dardot e Laval, é possível identificar a construção desse sujeito como resultado de uma norma produtora e gestora de subjetividades. Essa norma, por sua vez, encontra sua origem numa forma de governamentalidade explorada por Foucault - a biopolítica - e que, assentada sobre uma relação de poderes, "controla" um objeto populacional, um coletivo de vidas, dirigindo-os, educando-os, vigiando-os, para um determinado fim. 
Foucault parte dessa análise para construir seu raciocínio sobre o neoliberalismo, identificando na economia política o saber específico que organizará a governamentalidade biopolítica liberal a partir do século XVIII e neoliberal, a partir do século XX. Tal governamentalidade se faz exprimir por meio da norma que comanda os indivíduos e os educa e estimula a determinados fins, in casu, determinados pelo mercado. A norma, na sua função produtora, trabalha os sujeitos em duas partes; primeiro, dessingularizando-os para depois unificá-los em torno de uma forma subjetiva: o homem empresarial.

O fiel iurdiano, por outro lado, é um sujeito que constrói um sentido para si próprio através do catecismo da Igreja Universal. Nesse sentido, a igreja, não só no seu discurso, mas também na sua estrutura, desenvolve nos seus fiéis uma ética de um verdadeiro cuidado de si, de tornar-se ativo, de enxergar na palavra "empresário" um objetivo de vida ao mesmo tempo em que realiza um trabalho pedagógico de como atingir esse objetivo. A IURD, todavia, não deixa de ser uma instituição religiosa, e por isso todo esse processo de construção de um sujeito empresário é enclausurado em um ambiente simbólico e discursivo de natureza religiosa.

O discurso religioso, todavia, não é tudo. A IURD, para além da liturgia, apresenta uma estrutura destinada à vigilância constante e à educação permanente dos fiéis por meios "à distância" (como a Folha Universal, o "Eu sou a Universal" e o site oficial da igreja), mas também por meios "assessórios", a exemplo da constante observação da "inteligência emocional", do coaching, do networking e de outros elementos que encapsulam o homem iurdiano no cuidado de si para viver para outro a partir de si próprio. 


\section{Conclusão}

Toda a argumentação desenvolvida nas páginas acima foi pesquisada e trabalhada para estudar a possibilidade de construção de um sujeito neoliberal pela Igreja Universal do Reino de Deus e seu catecismo. Para que a conclusão do trabalho fique ainda melhor estruturada, farei um breve resumo de tudo que procurei expor até aqui.

No primeiro capítulo, desenvolvi a perspectiva, que já tinha explicado na apresentação do marco teórico-metodológico, de tratar o tema como o estudo de duas experiências que se cruzaram - a neoliberal e a religiosa, com recorte para o neopentecostalismo. Por esse motivo, iniciei com algumas abordagens sobre as mudanças sofridas pelo universo religioso ao longo do século passado, entre teorias de secularização e suas revisões para, a partir de Gauthier e Martikainen, estabelecer um ponto de partida para a análise a partir do conceito de prosperity religions e production values, que não compreendem uma secularização, colonização mercadológica ou desencantamento do religioso, mas antes são uma série de inovações litúrgicas, simbólicas e práticas surgidas no seio das grandes religiões tradicionais, que as inovaram na teologia e na prática.

Foi a partir desse ponto que busquei tomar o pentecostalismo como uma inovação religiosa ocorrida no seio do cristianismo tradicional para, a partir daí, avançar para o neopentecostalismo, o qual não é uma corrupção nem do pentecostalismo e nem do cristianismo, mas antes uma inovação dentro da inovação, com valores, práticas e públicos distintos e bem delimitados. Identifiquei, na esteira de Mariano, o surgimento da Igreja Universal do Reino de Deus como marco do surgimento do neopentecostalismo no Brasil e seu maior expoente, tomando essa igreja como objeto de análise. Considerando sua origem inovadora, busquei apresentar elementos do seu credo e da sua prática para destacá-la como exemplo de prosperity religion e para estabelecer um cenário dos seus fiéis e os valores que os agregavam junto à igreja. $\mathrm{Na}$ sua história e prática, identifiquei quatro valores eclesiológicos principais na IURD: a guerra santa, a ética da vitória, a fé inteligente e a teologia da prosperidade. 
No segundo capítulo, seguindo o marco usado no primeiro, procurei traçar uma breve história do Colóquio Walter Lippmann, que inaugurou o debate acerca da crise do liberalismo clássico e da necessidade de "restaurá-lo" ou substituí-lo por um "novo" liberalismo. Por respeito às pesquisas que fiz, e para reforçar o argumento de que "neoliberalismo" não é uma categoria unificada, iniciei a exposição sobre as alternativas ao liberalismo clássico com os ordoliberais alemães, em especial von Rüstow e Eucken, cujo projeto neoliberal indicava um resultado mais discrepante do que concordante com o "outro lado" do colóquio, os austroamericanos, e também com o pensamento de Lippmann, que é muito interessante pela sua particularidade.

A atenção principal do capítulo, todavia, estava voltada para as contribuições de Ludwig von Mises e Friedrich Hayek, que enfatizavam um papel central ao mercado não só como instrumento de mediação das trocas, mas principalmente como mecanismo de formação dos sujeitos. Mises centra o seu pensamento em torno da Ação Humana, a partir da qual o homem racional e calculista é capaz de enxergar no mercado um universo de possibilidades e aventuras capazes de lhe maximizar a satisfação material, e que as possibilidades de sucesso nessas aventuras seriam maximizadas se i) o sujeito se aperfeiçoasse e aumentasse sua eficácia de conduta no mercado por meio da empresa como formade-si; ii) se o mercado e seu funcionamento não fossem abalados por intervenções estranhas ao seu regular funcionamento. Hayek bebe na fonte de seu mestre Mises para atribuir ao mercado um espaço não só construtor do sujeito, mas construtor do mundo, recorrendo ao pensamento filosófico para tentar levar a questão da importância do mercado para além do debate econômico. O maior legado dos austroamericanos, portanto, é a defesa lupina do mercado como grande instrumento de desenvolvimento social, dispensando quaisquer intervenções e instituições e capacitado a uma função pedagógica de educação do sujeito "pelo mercado para o mercado". O processo é completado pela concorrência benéfica que o mercado impõe a todos os seus agentes, e pela assunção, pelo mercado, da garantia da liberdade humana.

No terceiro capítulo, dissertei sobre as bases para uma análise foucaultiana do neoliberalismo, com recurso também a outros autores, para entender por que (e qual a importância de) se entender o neoliberalismo como uma nova razão de 
mundo, ao invés de considerá-lo um novo espírito do capitalismo apesar de não procurar refutar aquela hipótese. Procurei desenvolver a importância do sujeito na construção do neoliberalismo, o que envolve dizer que o sujeito empresário de si mesmo é a unidade de medida da nova razão de mundo, porque é justamente essa assunção dos riscos da aventura mercadológica do sujeito por ele mesmo que é possível falar em concorrência como norma generalizada (porque todos os sujeitos vão competir entre si pela maior satisfação no mercado), e na empresa como forma de vida (pois os sujeitos passarão a orientar a própria conduta com base nos ganhos e perdas que podem resultar das suas ações).

Essa visão generalizada das coisas como oportunidades, concorrentes, colaboradores e ganhos e perdas só é possível quando o mundo e a vida se transformam um grande mercado, com trocas, oportunidades e experiências. Daí a nova razão do mundo. A autoimputação dessa conduta pelo sujeito é realizada por meio do aspecto biopolítico da governamentalidade neoliberal. Essa governamentalidade se sustenta por meio de um controle de biopoderes, que agem não sobre a vida, mas junto à vida, e são instrumentalizados por uma norma que molda os sujeitos por meio da dessingularização e unificação existencial de maneira a adaptá-los à gramática biopolítica do mercado, que se inscreve como espaço formador da verdade.

Nesse capítulo também procurei identificar na IURD uma instituição normatizadora dos corpos, das condutas e dos desejos, seja por meio do discurso, seja por meio da própria instituição, que se dedica a uma catequese consumerista dos sujeitos e os estimula à busca da riqueza e autorrealização por meio de uma ação "inteligente" (ao qual a sua fé serve de escopo e estímulo). Vendo na riqueza, no consumo e na satisfação a obra divina, o fiel iurdiano aprende na igreja que tais "bênçãos" só são possíveis pela ação independente (e do cuidado-de-si sob a forma empresa) pela obediência à igreja.

O trabalho, assim, procurou cruzar as duas experiências. O resultado mostrou que a Igreja Universal é uma instituição dotada de uma capacidade de controle, moldura e educação considerável sobre os seus fiéis, e que tem um projeto de mudança de vida para os indivíduos que adentram seus templos. A igreja, por meio de recursos psicológicos, litúrgicos e pedagógicos (como os seus cursos 
paralelos), consegue desenvolver nos fiéis uma visão de si e do mundo, de ampliação do horizonte do desejo, capacitação profissional, estímulo à independência própria e autodisciplina e vigilância que são suas marcas e podem explicar o sucesso que a Universal fez nos seus mais de quarenta anos de existência.

A igreja, assim, fornece um know-how ao seu rebanho, e um caminho para mudar de vida. Em primeiro lugar, impõe a disciplina com o próprio eu e potencializa o sujeito conforme o caso (o viciado, o desalentado, etc), por meio de programas como o "a última pedra"; em segundo lugar, incute o cuidado-de-si e do outro por meio do desenvolvimento afetivo, visando estabelecer uma unidade familiar responsável (como por meio da terapia do amor, do casamento blindado e dos encontros de solteiros e de casais). Por fim, é em ambientes como a Nação dos 318 e do Congresso para o Sucesso Financeiro que a Universal completa a obra, preparando o fiel para a aventura mercadológica.

Essa perspectiva educativa e potencializadora reflete dois pontos que procurei levantar no início do trabalho. Em primeiro lugar, ela derruba algumas críticas feitas à IURD, acusando-a de "tenda de milagres", curandeirismo e charlatanismo, de que não passa de uma instituição financeira disfarçada de igreja que usa a teologia da prosperidade para enganar os fiéis a ofertarem o dízimo. A IURD não está livre de críticas, e meu trabalho não serve para refutar ou ratificar nenhuma delas, mas ainda que a IURD fosse uma falperra de ladrões que rouba o dinheiro dos fiéis, uma hora a fonte seca e "a casa cai". A Igreja Universal tem seu tamanho e sua força porque ela tem esse projeto de empoderamento dos fiéis, e mais: ele é bem sucedido. A cerimônia de inauguração do Templo de Salomão teve orquestra tocando obras de Ernest Gold, que ecoaram no mármore do templo, trazido de Israel. Qualquer pecha à IURD como religião de pobre acaba naquela cerimônia, à qual muitos fiéis assistiram. Certamente alguns eram empresários bem sucedidos que chegaram onde chegaram por causa da igreja.

Seguindo esse raciocínio, há um comentário a ser feito sobre a Igreja Universal como "religião da ralé", que também foi levantada na introdução. Segundo uma interpretação possível, o neopentecostalismo seria o substrato ideológico que permite à ralé e aos "batalhadores" mencionados por Jessé Souza a perseverança no fenômeno capitalista. Essa é uma interpretação que segue o 
raciocínio "espiritual" de Boltanski e Chiapello e, em que pese os seus méritos acadêmicos, parece deixar alguns pontos problemáticos. Em primeiro lugar, pressupõe a existência de uma superpotência no poder capitalista, capaz de reger a vida de maneira quase absoluta, inclusive produzindo "ideologias" para mascarar a própria violência e "suavizar" a exploração. O capitalismo é um fenômeno complexo e possui uma plasticidade singular, evidenciada pelas suas transformações. Não se deve negar ao capital um papel participativo na História contemporânea; nem negar a relação entre capitalismo e neoliberalismo. Mas as perspectivas de um capital imperador, "grande relojoeiro", que necessita de um discurso para potencializar o indivíduo de maneira a liberar a sua força de trabalho e oferecê-la contratualmente sem perceber a violência intrínseca ao processo parece gerar um paradoxo: o capital potencializa o sujeito, (como Marx já afirmava no manifesto) e ainda assim o sujeito é impotente para romper "os grilhões que o prendem"? Ou ainda; o capital cria as ideologias religiosas e o neoliberalismo com sua "neo-liberdade" estética para alienar o sujeito (agora potencializado) da sua própria condição?

Tais análises parecem levar a dois resultados: ou o sujeito é absolutamente impotente, ao menos que o capital o potencialize, mas isso reduziria toda a História humana à História do capital (e à não-História, portanto); ou o sujeito pode se autopotencializar, mas é imediatamente "capturado" pelos mecanismos alienadores e sintetizadores de potência, fazendo com que o sujeito caísse vítima da própria derrota para o capital; ou seja, nunca foi potente. Se o neoliberalismo envolve uma verdadeira potencialização do indivíduo, por meio do cuidado-de-si e da busca pela eficácia, então em nenhum desses cenários ele é possível. O humano enquanto sujeito histórico sempre tem a capacidade de potência. Caso contrário, não haveria História.

O processo potencializador e educacional da IURD está aí para comprovar a capacidade das instituições potencializarem o sujeito e de, em certos casos, emancipá-lo da situação de penúria em que se encontra. Em outras palavras: dar à ralé um futuro, diferente do seu "eterno presente". É claro que não se pode afirmar nem que todos os fiéis da IURD desejem ser empresários, e nem que a IURD tenha um plano de "empresariar" todos os seus fiéis. A igreja é enorme, e apesar de ter um público fiel, o público flutuante também deve existir, sendo impossível 
controlar todos os elementos e variáveis na sua equação de construção subjetiva. Gostaria de reafirmar também que como me preocupei com uma educação empresarial na igreja, não pesquisei projetos alternativos que ela eventualmente desempenhe junto a outros segmentos de fiéis, principalmente em outros países. Além disso, apesar dos fortes estímulos à realização material e ao consumo feitos pelo neoliberalismo e pela prática da igreja, não se pode dizer nem que sejam a mesma coisa, ou que sejam inteiramente equivalentes, principalmente se tomados como projetos: o desenvolvimento do mercado pressupõe a desigualdade constante dos seus partícipes para que possa funcionar como espaço de descobertas e oportunidades, ao passo que a teologia da prosperidade, dado o seu caráter de "promessa divina", parece oferecer uma oportunidade de igualdade a todos os homens, neste mundo e no outro, atingível a partir da atitude de fé e da obra do Espírito.

Por fim, a questão de se encaixar a Igreja Universal como prosperity religion parece válida. Conforme disse na introdução, tratei a IURD como uma religião, como trataria qualquer outra. A sua particularidade reside no seu surgimento a partir da ressignificação dos símbolos do pentecostalismo e de alguns elementos de fora do cristianismo (como os orixás, o galhinho de arruda e o banho de sal grosso), e não da invenção de uma coisa nova, ou eivada de sentido, conforme Champion, ou colonizada pela linguagem mercadológica, como Berger classificou as novas religiões. Antes, me pareceu uma denominação cristã, com a particularidade de sua capacidade de production values; e é a partir dessa nova possibilidade de interpretação dos valores religiosos que tanto a ênfase que a IURD põe nos bens materiais como sinal de salvação quanto a interpretação do empreendedorismo em veículo de graça, feita pelo Padre Sirico, parecem ter gênese. A redescoberta de manifestações do divino e da bênção ou maldição e principalmente, uma nova ética religiosa, voltada para a produção e observação de valores novos. Tratar dos production values como eventuais formas de controle de conduta ou como espaços formadores de verdade, à moda foucaultiana, não parece impossível, mas exigiria um trabalho próprio, de modo que uma análise possível sobre os production values na IURD seria a seguinte: o fiel frequente da Igreja Universal realmente leva para casa os valores que aprende lá e os pratica incessantemente, de maneira disciplinada. Ele sabe que Deus, seu potencial sócio, está vendo. 
5

\section{Referências bibliográficas}

AUDIER, Serge; REINHOUDT, Jurgen. The Walter Lippmann Colloquium - The

Birth of Neoliberalism. Basinstoke. Palgrave Macmillan. 2018.

BIDET, Jacques. Foucault with Marx. London. Zed Books. 2016

BOWKER, John (Org.). The Oxford Dictionary of World Religions. Oxford. Oxford University Press. 1997

CAMPÁ, Wânia Amélia Bechior Mesquita. “O Empresário e a Fé - "Homens de negócio" e expansão pentecostal. Trabalho apresentado no seminário temático ST01 "Os pentecostais". VIII Jornadas sobre Alternativas Religiosas na América Latina São Paulo, 22 a 25 de setembro de 1998.

DARDOT, Pierre; LAVAL, Christian. A Nova Razão do Mundo - Ensaio sobre a Sociedade Neoliberal. São Paulo: Ed. Boitempo. 2016

DARDOT, Pierre; LAVAL, Christian. Uma alternativa ao Neoliberalismo. Entrevista concedida a Daniel Pereira Andrade e Nilton Ken Ota. In: Tempo Social, revista de Sociologia da USP, v. 27, n. 1.2015

EUCKEN, Walter. Fundamentos de Politica Económica. Madrid. Ed. Rialp. 1956 (Tradução castelhana de Grundsätze der Wirtschaftpolitik, por José Luis Gómez Delmás)

FERRARI, Odêmio Antônio. Bispo S/A: A Igreja Universal do Reino de Deus e o Exercício do Poder. Goiânia. Ed. Ave Maria. 2007

FOUCAULT, Michel. Nascimento da Biopolitica - Curso no Collège de France (1978-1979). São Paulo: Ed. Martins Fontes. 2008

FOUCAULT, Michel. Sécurité, Territoire, Population - Cours au Collège de France (1977-1978). Paris. Editions EHESS-Gallimard-Seuil. 2004

FRESTON, Paul. Protestantes e Política no Brasil: Da Constituinte ao Impeachment. Tese de Doutorado, Unicamp, 1993 
GIUMBELLI, Emerson. "A Vontade de Saber: Terminologias e Classificações sobre o Protestantismo Brasileiro". Revista Religião e Sociedade (ISER). Rio de Janeiro. v. 21.pp. 87-119. 2001

GIUMBELLI, Emerson. "Religiões no Brasil dos anos 1950: processos de modernização e configurações da pluralidade". PLURA, Revista de Estudos de Religião (ABHR). São Paulo. v. 03, n. 1. pp. 19-96. 2012

GUTIERREZ, Carlos Andrade Rivas. A Reflexividade Evangélica a partir da produção crítica e a construção de projetos de vida na Igreja Universal do Reino de Deus. Tese de Doutorado em Antropologia Social. Orientação de Ronaldo Rômulo Machado de Almeida. Campinas. Unicamp. 2017

HAYEK, Friedrich A. Individualism and Economic Order. Chicago: The University of Chicago Press. 1948

HAYEK, Friedrich A. The Fatal Conceit: the errors of Socialism. Chicago: The University of Chicago Press. 1988

HUXLEY, Aldous. Ends and Means - An Inquiry into the Nature of Ideals and into the Methods employed for their Realization. London: Chatto \& Windus. 1938

LAVAL, Christian. Foucault and Bourdieu: To each his own Neoliberalism?. In Revista Sociologia e Antropologia (IFCS-UFRJ). Rio de Janeiro. v. 07-01. pp. 6375. Abril de 2017.

LAVAL, Christian. Foucault, Bourdieu et la Question Néolibérale. Paris. Éditions la Découverte. 2018

LIPPMANN, Walter. An Inquiry into the principles of the Good Society. Boston. Little Brown and Company. 1943 (2a Ed)

MACHEREY, Pierre. Le Sujet des Normes. Paris. Éditions Amsterdam. 2014

MARIANO, Ricardo. “Os Neopentecostais e a Teologia da Prosperidade”. In: Novos Estudos (CEBRAP). São Paulo. n. 44, pp. 24-44, Março/1996 
MARIANO, Ricardo. Igreja Universal do Reino de Deus: A Magia Institucionalizada. In. Revista USP. São Paulo. v. 31. pp. 120-131. Setembro/Novembro 1996

MARIANO, Ricardo. Neopentecostais - Sociologia do Novo Pentecostalismo no Brasil. São Paulo: Ed. Loyola. 1999

MARIANO, Ricardo. “O Debate acadêmico sobre as práticas monetárias da Igreja Universal. Trabalho apresentado no Encontro Anual da ANPOCS, outubro de 1998, Caxambu, Minas Gerais.

MARIANO, Ricardo. A Igreja Universal no Brasil. In ORO, Ari Pedro et al. (Orgs.) Igreja Universal do Reino de Deus: Os novos conquistadores da Fé. São Paulo. Paulinas. 2003a

MARIANO, Ricardo. O Reino de Prosperidade da Igreja Universal. In ORO, Ari Pedro et al. (Orgs.) Igreja Universal do Reino de Deus: Os novos conquistadores da Fé. São Paulo. Paulinas. 2003b

MARIANO, Ricardo. Expansão pentecostal no Brasil: o caso da Igreja Universal. Revista Estudos Avançados. São Paulo. v.18, pp.121-137, 2004.

MARTIN, David. Tongues of Fire: the explosion of protestantism in Latin America. Oxford. Blackwell. 1990

MARTINS, Erik Fernando Miletta. Frames Neoliberais na Retórica Neopentecostal - Aspectos referenciais e sociocognitivos. Tese de Doutorado, Unicamp, 2015. Orientação da Profa. Dra. Edwiges Maria Morato

MORAIS, Edson Elias de. Religiosidade Contemporânea - Aproximações ente Neopentecostalismo e Neoliberalismo. Dissertação de Mestrado. Universidade Estadual de Londrina, 2013. Orientação do Prof. Dr. Fabio Lanza

MIROWSKI, Philip; PLEHWE, Dieter. The Road from Mont-Pèlerin - The making of the Neoliberal Though collective. Cambridge (MA): Harvard University Press. 2009

MISES, Ludwig von. Human Action - A Treatise on Economics. Indianapolis: Liberty Fund. 2007 
PROENÇA, Wander de Lara. Sindicato de Mágicos: uma história cultural da Igreja Universal do Reino de Deus (1977-2007). São Paulo. Ed. Unesp. 2011

REVEL, Judith. Foucault, un pensamiento de lo discontinuo. Buenos Aires. Amorrortu editores. 2014. (Tradução de Irene Agoff).

RÖPKE. Wilhelm. Civitas Humana - A Humane Order of Society. London. William Hodge \& Co.. 1948 (Tradução de Cyril Spencer Fox)

SÁNCHEZ, Jesús Hortal. A Pentecostalização do Brasil x Os 'sem religião': cura e exorcismo. Entrevista concedida a Renato da Silveira Borges Neto. In Revista Telecomunicação. Porto Alegre. V. 44, n. 2. Pp. 181-195, mai-ago. 2014

SOUSA, Bertone. Fé e Dinheiro - O pentecostalismo da prosperidade e a redefinição do protestantismo no Brasil. São Paulo: Ed. Paco Editorial. 2015

SOUZA, Jessé. A Ralé Brasileira - Quem é e como vive. Belo Horizonte: Ed.UFMG.2009

TORRES, Roberto. Neopentecostalismo e o novo espírito do Capitalismo na Modernidade Periférica. In: Perspectivas, São Paulo, v. 32, p. 85-125, jul./dez. 2007

ZIPPELIUS, Reinhold. Teoria Geral do Estado. Lisboa. Editora da Fundação Calouste Gulbenkian. 1997 (3a Ed) 